\title{
جماليات "الإيقاع" في الفن الفرعوني والاستفادة هنه في تصميم أزياء للمراهقين
}

\author{
إعلاد \\ كـرامة ثابت حســ الشيخ \\ أستاذ مساعد بقسم الملابس والنسيج \\ كلية الاقتصاد المنزلي - جامعة حلوان
}

مجلة بجوث التربية النوعية ـ جامعة المنصورة

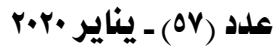




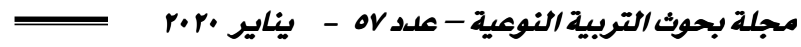

جماليات "الإيقاع" في الفن الفرعوذي والاستفادة هنه في تصميم أزياء للمراهقين

| - إعداد

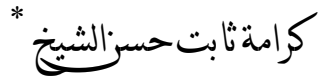

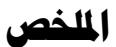

الإيقاع أحد أهم جماليات أسس التصميم، وهى (الوحدة- التوازن- التناسب-

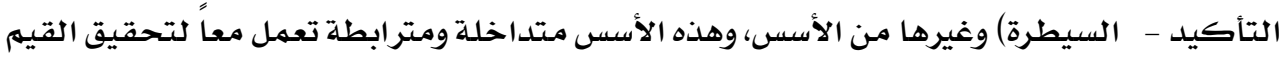

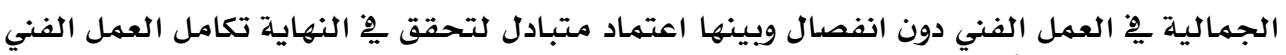

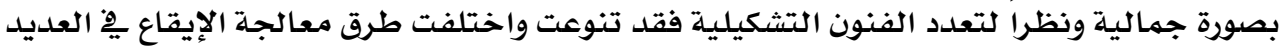

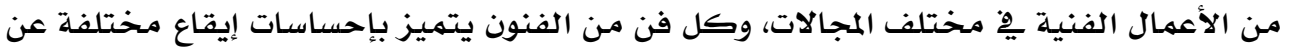

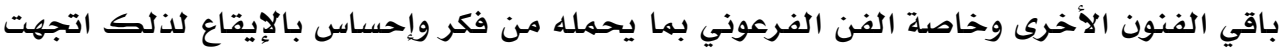

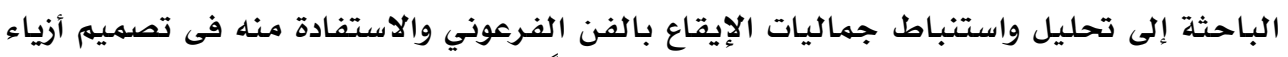

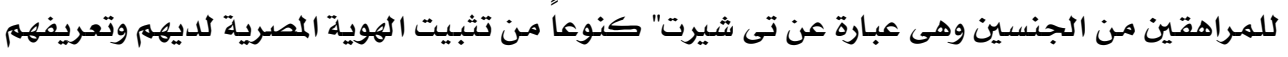

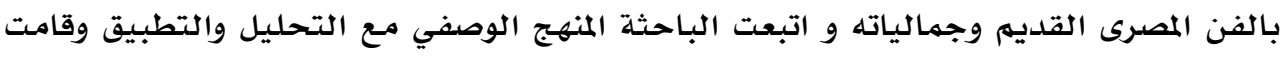

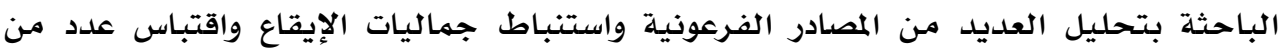

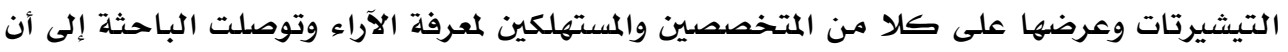

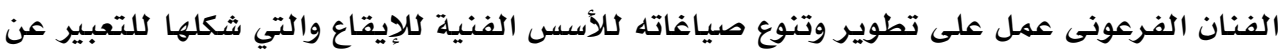

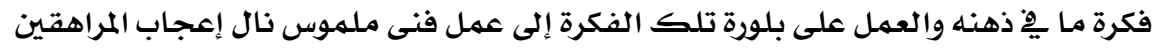

مقدمهة:

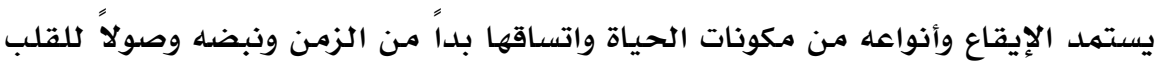

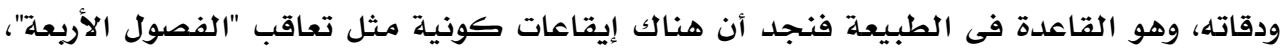

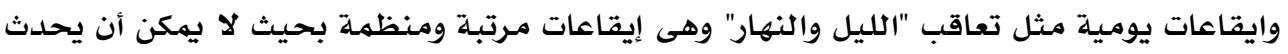

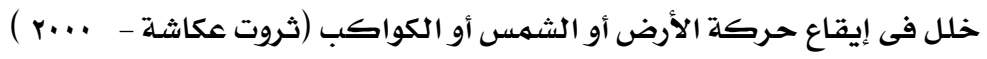

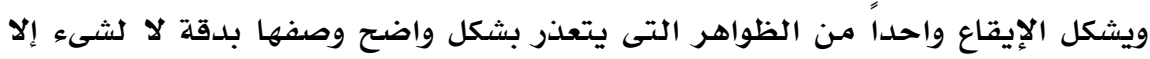

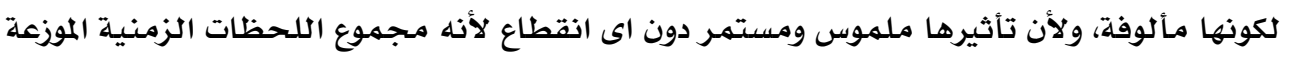

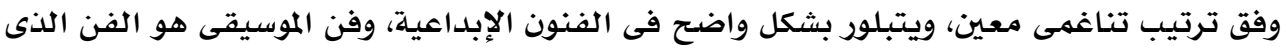

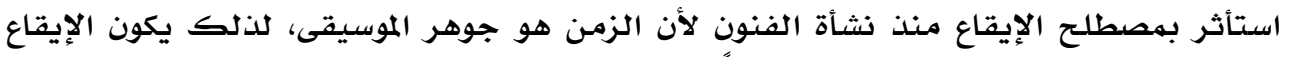

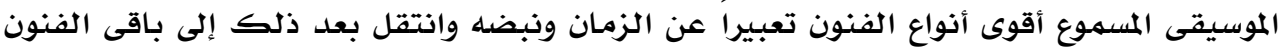

" استاذ مساعد بقسه الملابس والنسيج - كلية الاقتصاد المنزلى - جامعة حلوان 
"إيقاع الشعر، إيقاع النثر، إيقاع اللون والضوء والحركة فى اللوحات الفنية" ( Ramesh Chopra

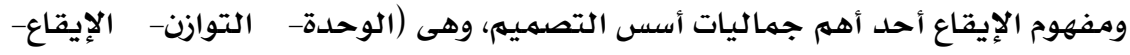

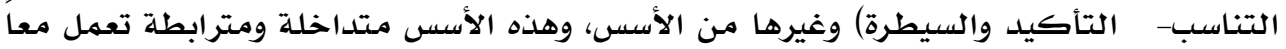

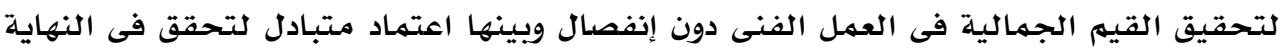

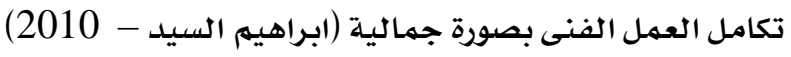

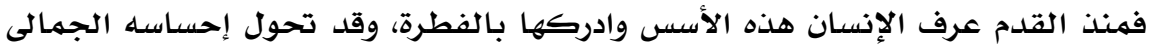

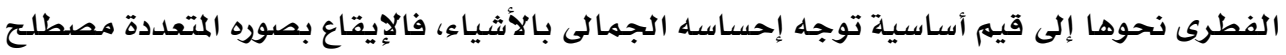

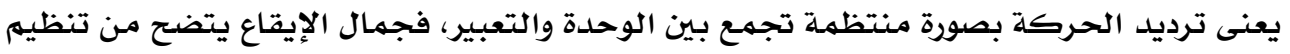

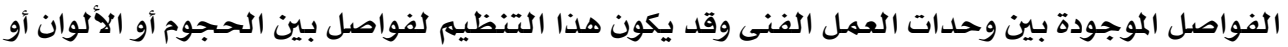

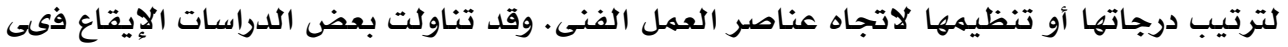

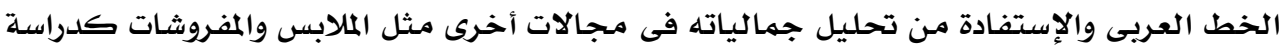

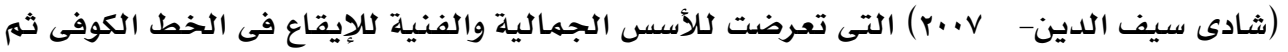

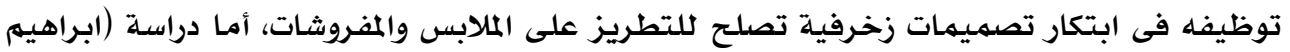

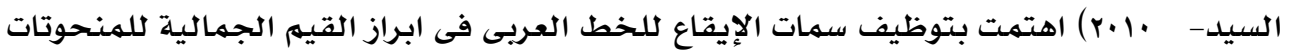

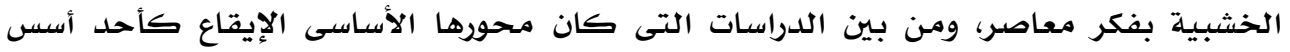

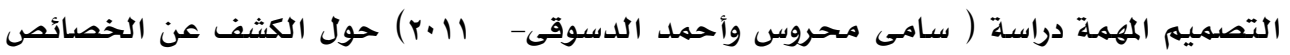

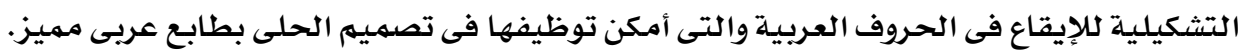

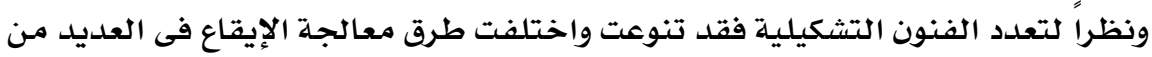

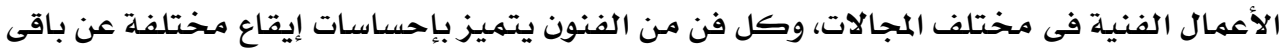

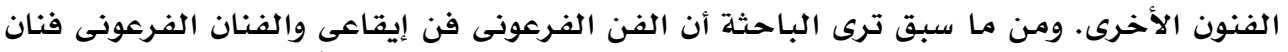

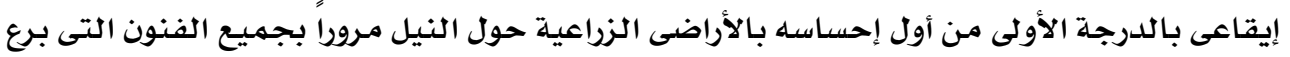
فيها فى كل العصور الفرعونية المتتابعة.

فالتاريخ الفرعونى هو تاريخ الحضارة الإنسانية حيث أبدع الفنان المصرى القديم وقدم

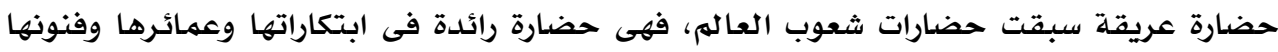

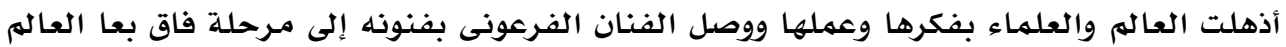

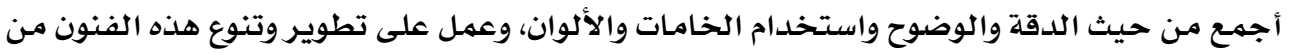

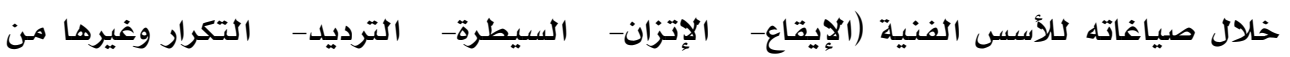

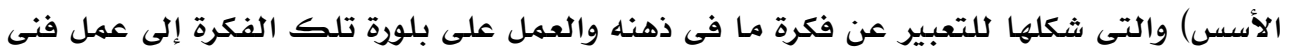

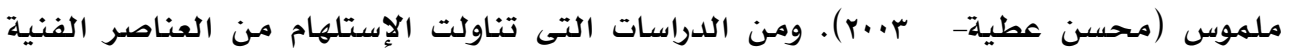

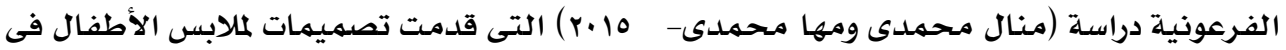

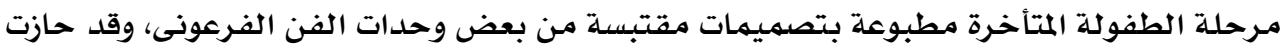


التصميمات على إعجاب الأطفال بلدرجة عالية، وكذلك دراسـة (رجاء عبد الخالق- 2018) التى

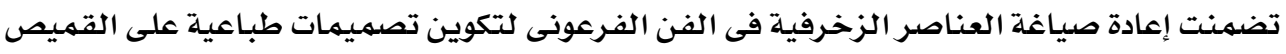

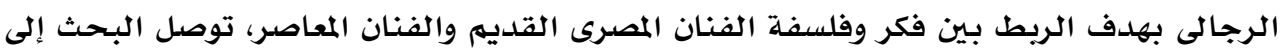

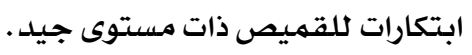

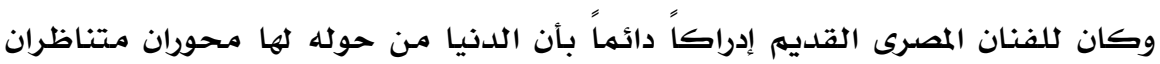

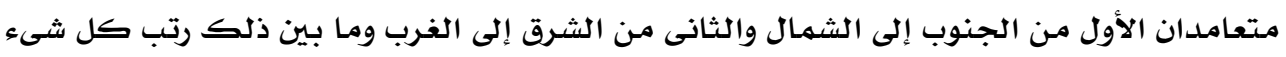

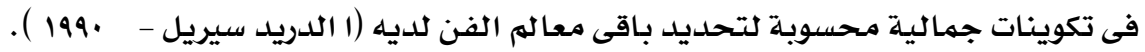
يعد تصميه الأزياء فن من الفنون التطبيقية المتخصصة لتصميه الملابس، وجزء من التصن

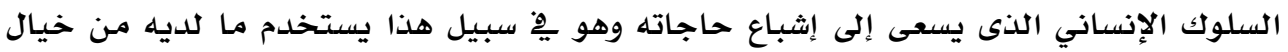

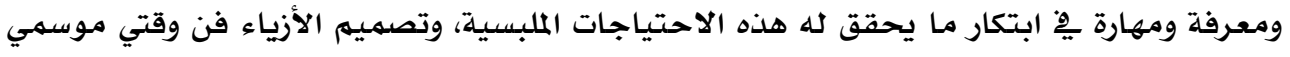

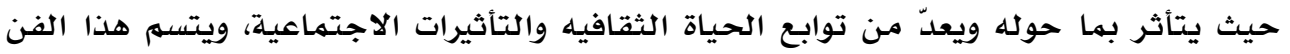

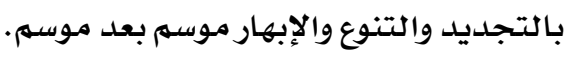

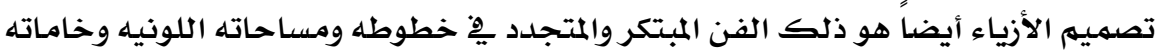

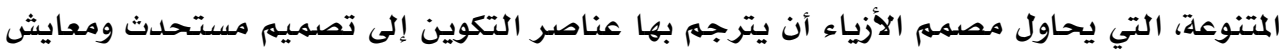

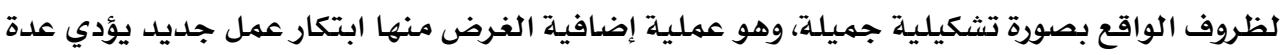

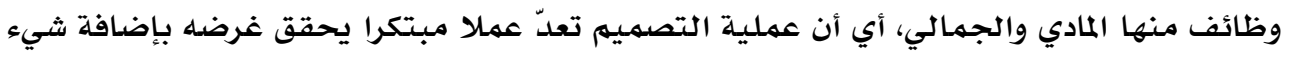

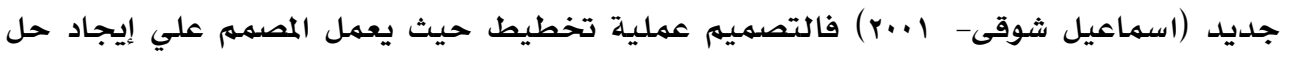

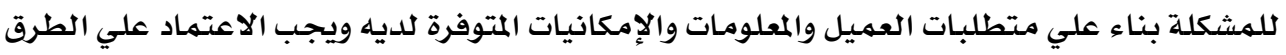

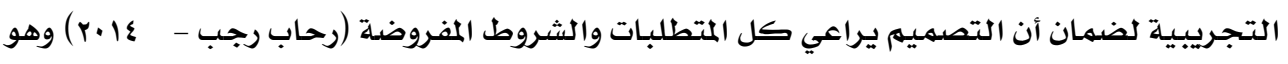

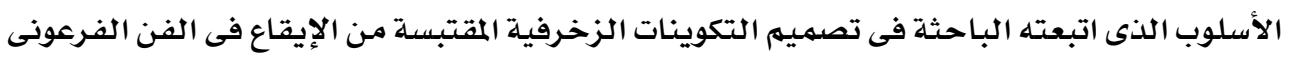
للبحث الحالى.

وتعتبر المراهقة من أهم الفترات التى يهر بها الإنسان فى حياته بل يهكن اعتبارها فترة

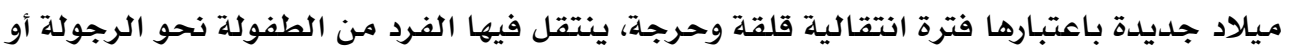

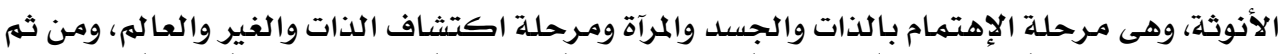

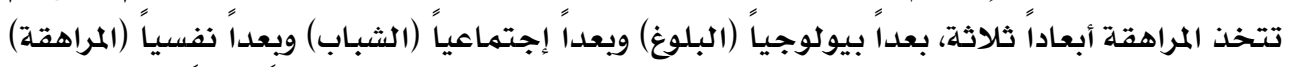

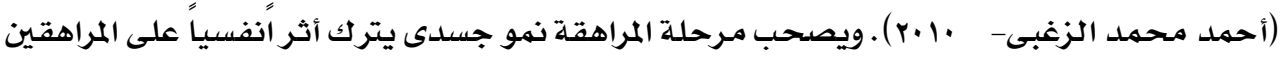

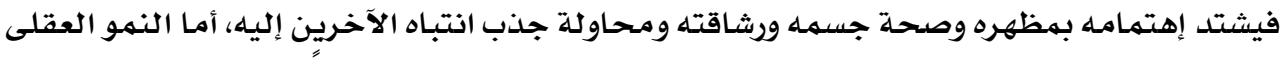

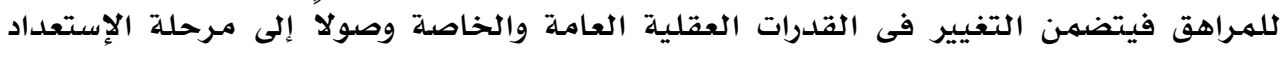

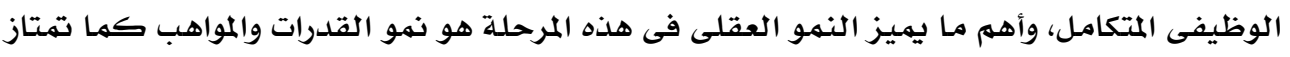

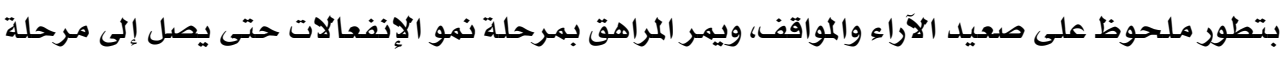

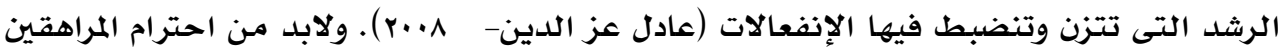

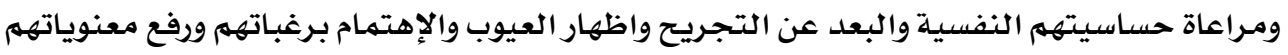




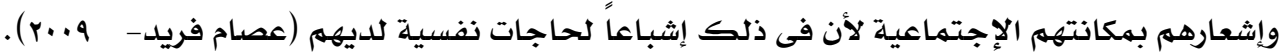

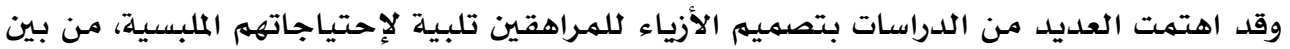

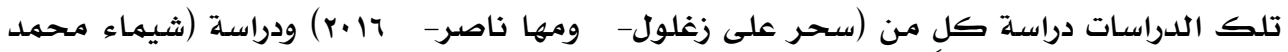

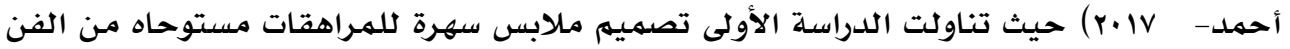

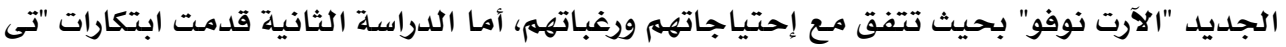

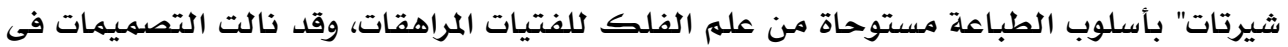

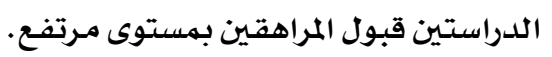
ومن العرض السـابق ترى الباحثة ضرورة الإهتمام بتحقيق متطلبات المراهقين والإستجابة

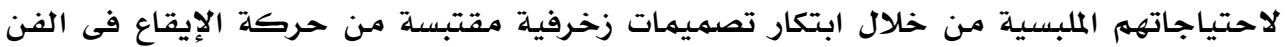

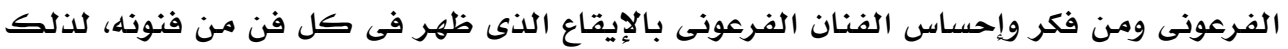

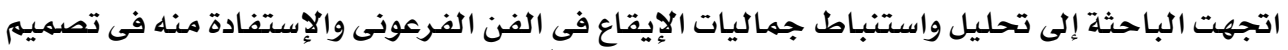

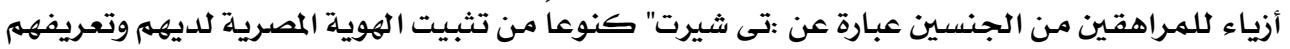

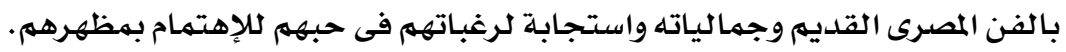

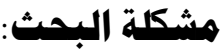

$$
\text { انحصرت مشكلة البحث فى الآتى: }
$$

ا ـ ما السمات المميزة للإيقاع وأنواعه كأحد أسس التصميه؟

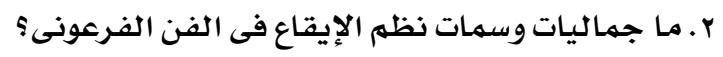

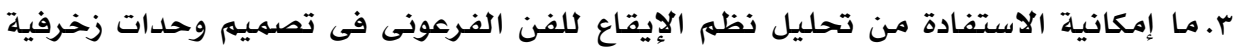

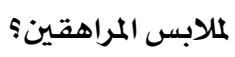

ع. ما آراء المتخصصين فى الأزياء تجاه تصميمات ملابس المراهقين التى تحتوى على وحدات

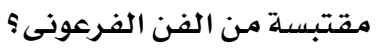

ه. ما آراء المراهقين من الجنسين تجاه تصميمات الملابس التى تحتوى على وحدات مقتبستة من

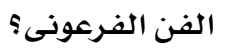

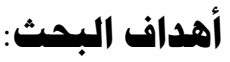

$$
\text { يهدف البحث إلى ما يلى: }
$$

ا ـ تحديد السمات المميزة للإيقاع وأنواعه كأحد أسس التصات لتصميه.

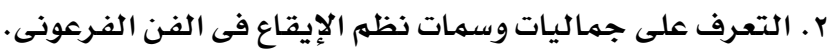

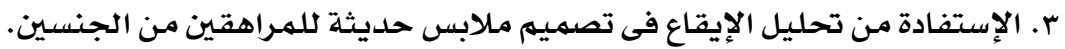

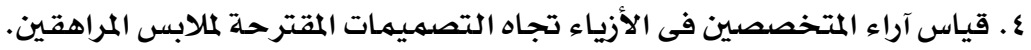
ه. قياس آراء المراهقين من الجنسين نحو تصميمات الملابس المقترحة لهم فى البحثي. 


$$
\text { تتضـح أهمية البحث فى الآتى: }
$$

ا ـ قد تضيف مـلابس المراهقين المقترحة فى البحث فكر جديد برؤيدية معاصرة. r r تعريف المراهقين بالفن الفرعونى كقيمة تشكيلية للتأكيد على الهوية المصرية.

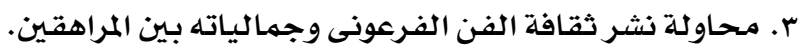

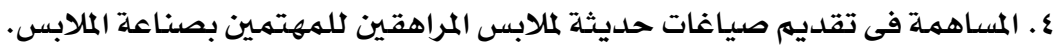

\section{همطاحات البمث:}

ا. الإيقاع :Rhythm: هو تكرار الكتل أو المساحات مكونة وحدات قد تكون متماثلة تمامـاً أو

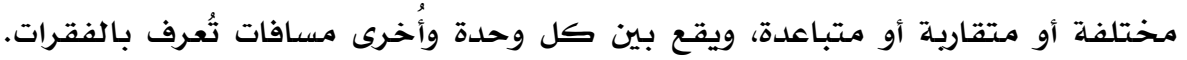

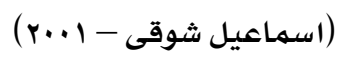

r. كما يعنى ترديد الحركة بصورة منتظمة تجمع بين الوحلدة والتكامل، كما يعنى ترديد

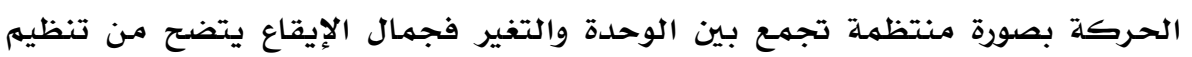

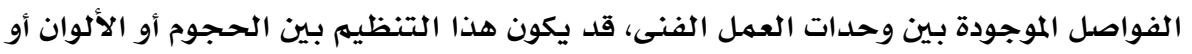

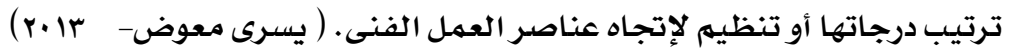

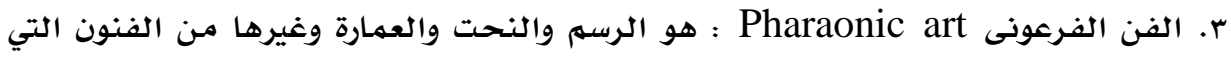

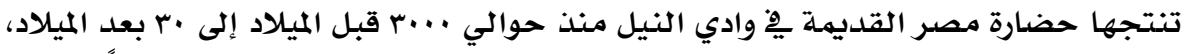

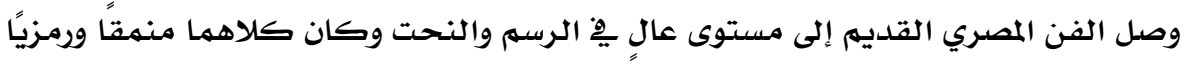

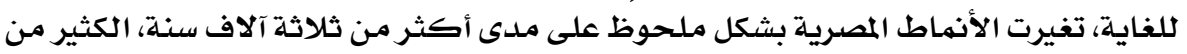

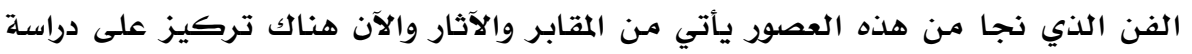

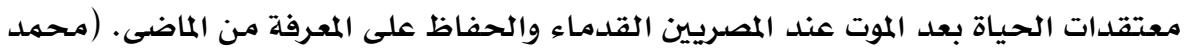

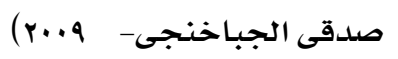

ع. تصميم الأزياء fashion design : هو اللغة التي تشكلها مجموعة عناصر (الخط والشكل

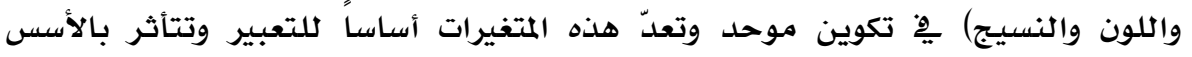

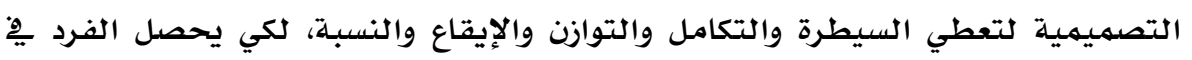

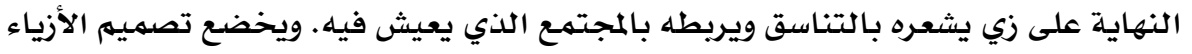

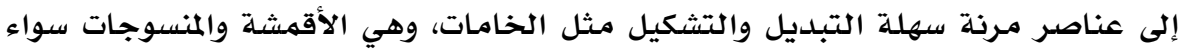

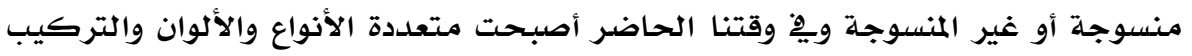

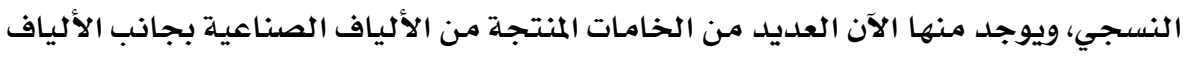

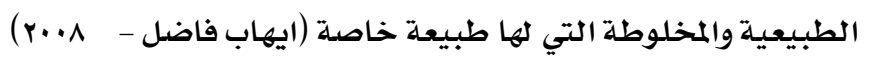

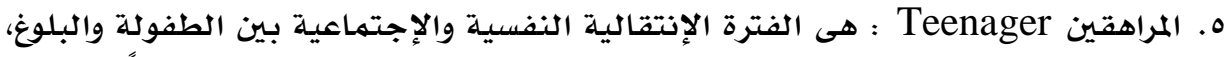

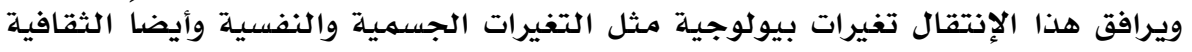




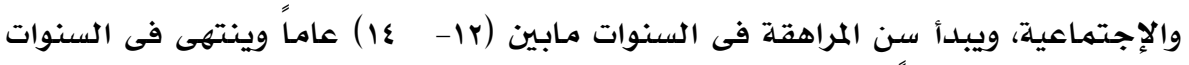

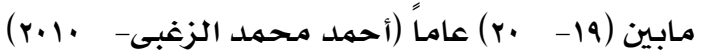

\section{حدود البمث:}

يقتصر البحث على المحلددات الآتية:

1.الإيقاع كأحد أسس التصميه.

r. بظم الإيقاع فى العصر الفرعونى.

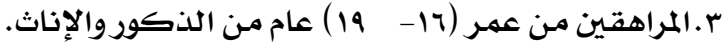

ع.التى شيرت.

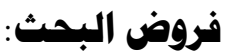

يقوم البحث على الفروض الآتية:

ا. توجد فروق ذات دلالة إحصائية بين التصميمات العشر ِِّ تحقيق المحور (الجمالى-

$$
\text { الوظيفى- الكلى) وفقا لأراء المتخصصئ. }
$$

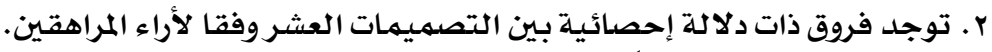

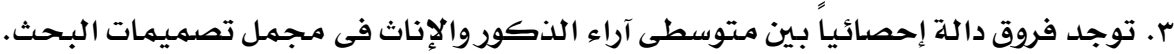

مندهج البحث:

اتبع البحث المنهج الوصفى مـع التحليل والتطبيق لأنه المنهج المناسب لموضوع ومشكلة

$$
\text { البحث للوصول إلى نتائج. }
$$

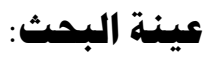

تطلب البحث نوعين من العينات هما كالتالى:

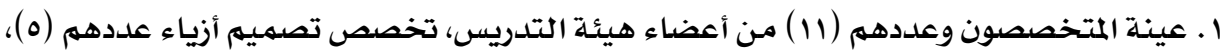

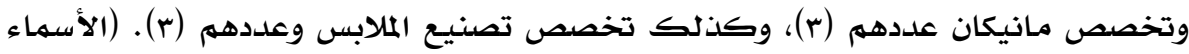

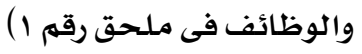

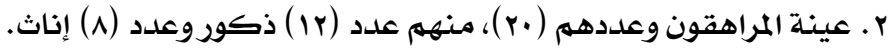

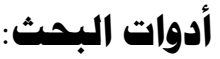

$$
\text { اولاً: استبيان المتخصصون: فى ملحق البحث رقباء الأدوات الآتية: }
$$

يهدف الإستبيان إلى التعرف على آراء المتخصصون من أعضاء هيئة التدريس تجاه

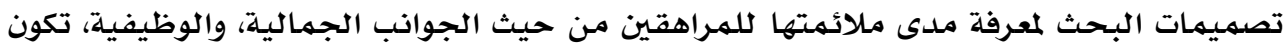
بناء الإستبيان من الغلاف الذى تضمن عنوان موضوع البحث والهدف منهه وكيفية تسجيل ملهيل 
الإستجابات، كما تضمن مكان لتسجيل البيانات وهى الإسه، والتخصص، بالإضافة إلى التاريخ

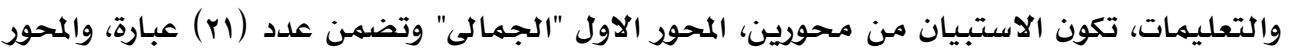

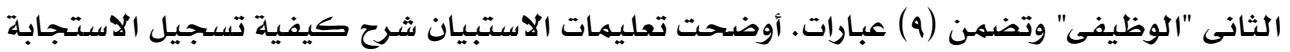

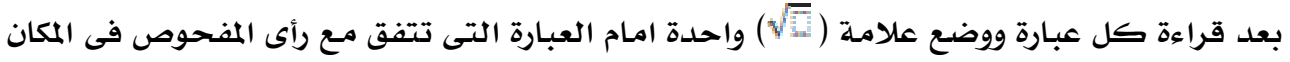

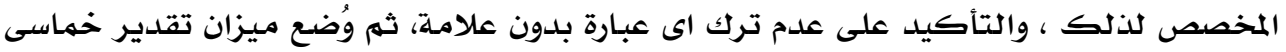

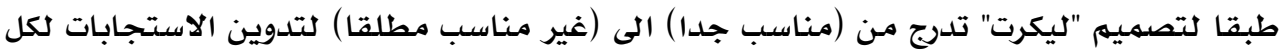

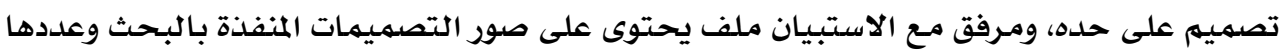

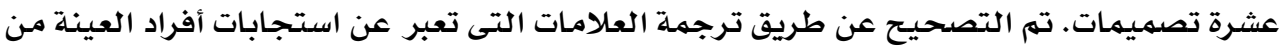

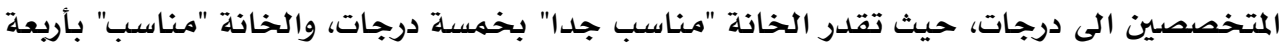

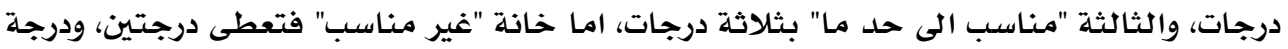

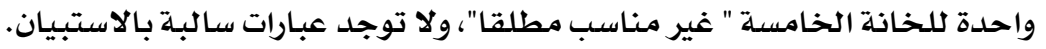
الصدل: تم إجراء الصدق باستخدام الاتساق الداخلي عن طريق معامل ارتباط بيرسون بين

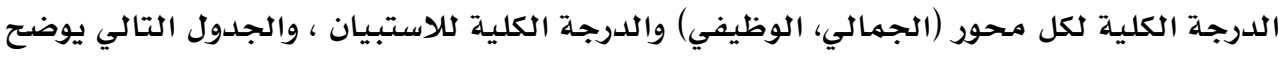
ذلك :

\begin{tabular}{|c|c|c|}
\hline \multicolumn{3}{|c|}{ جمالي، الوظيفي) والدرجة الكلية دلاستبيان } \\
\hline الدلالة & الارتباط & المحاور \\
\hline 0.01 & 0.851 & 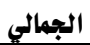 \\
\hline 0.01 & 0.922 & الوظيفي \\
\hline
\end{tabular}

يتضح من الجدول أن معاملات الارتباط كلها دالة عند مستوى (0.01) لاقتراب قيمها

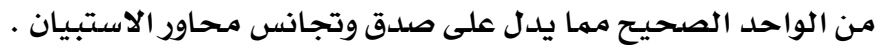
الثبات: تم حساب الثبات عن طريق معامل الفا كرونباخ Alpha Cronbach ، وطريقة

Split-half التجزئة النصفيات التمات جدول رقم ( r ) قيم معامل الثبات لمحاور الاستبيان

\begin{tabular}{|c|c|c|}
\hline التجزئة النصفية & معامل الفا & المحاور \\
\hline $0.803-0.712$ & 0.763 & الجمالي \\
\hline $0.958-0.860$ & 0.915 & الوظيفي \\
\hline $0.897-0.801$ & 0.851 & ثبات الاستبيان ككل \\
\hline
\end{tabular}

يتضـح من الجدول السابق أن جميع قيهم معاملات الثبات : معامل الفا ، التجزئة النصفية

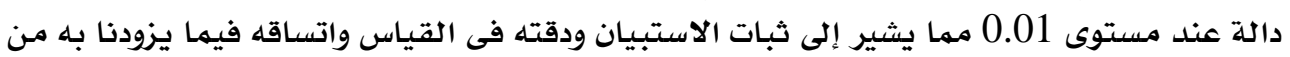
معلومات عن آراء المفحوصين 


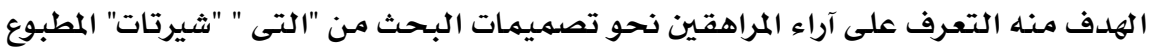

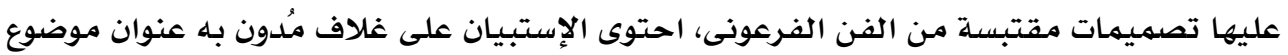

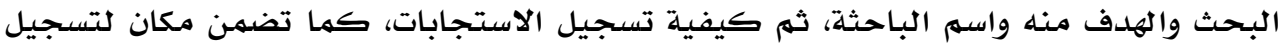

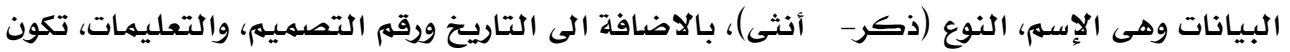

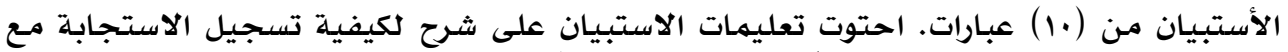

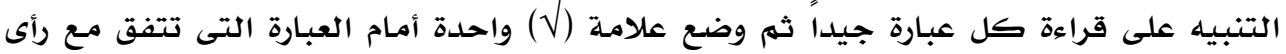

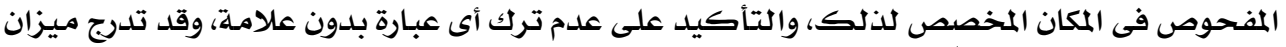

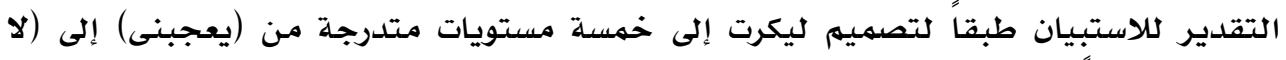

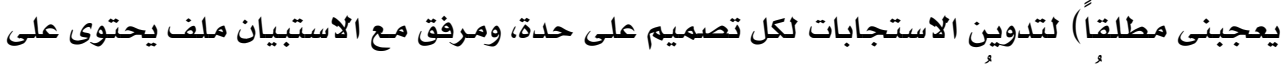

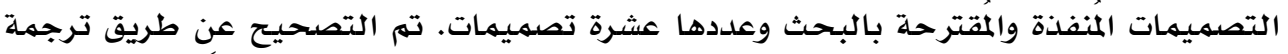

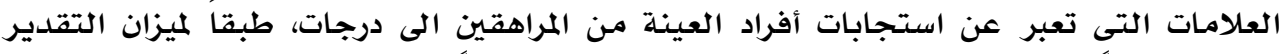

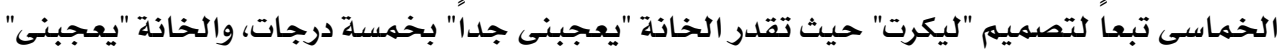

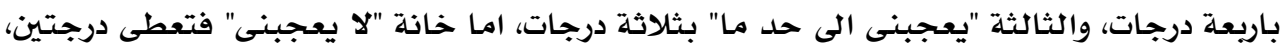

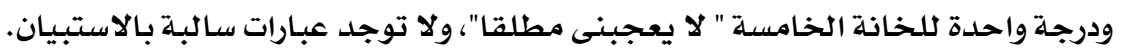

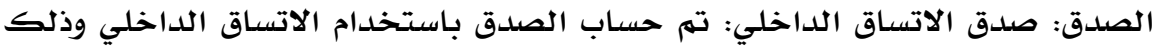

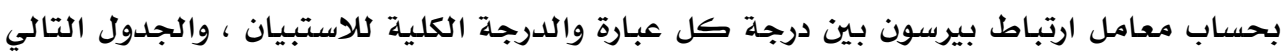

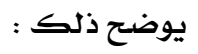

جدول (r) قيم معاملات الارتباط بين درجة كل عبارة والدرجة الكلية للاستبيان

\begin{tabular}{|c|c|c|c|c|c|}
\hline الدلالة & الارتباط & A & الدلالة & الارتباط & P \\
\hline 0.01 & 0.915 & -7 & 0.01 & 0.776 & 1 \\
\hline 0.01 & 0.847 & $-y$ & 0.05 & 0.640 & $-r$ \\
\hline 0.05 & 0.623 & -1 & 0.01 & 0.882 & r \\
\hline 0.01 & 0.725 & -9 & 0.01 & 0.946 & عـ \\
\hline & & & 0.01 & 0.813 & _ 0 \\
\hline
\end{tabular}

يتضح من الجدول أن معامـلات الارتباط كلها دالة عند مستوى (0.01 - 0.05) لاقتراب

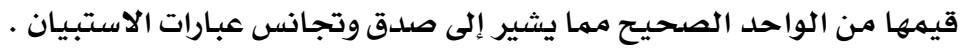
الثبات: تم حساب الثبات عن طريق معامل الفا كرونباخ Alpha Cronbach ، وطريقة

Split-half التجزئة النصفيات تهياب

جدول (ع) قيم معامل الثبات لإستبيان المراهقين

\begin{tabular}{|c|c|c|}
\hline التجزئة النصفية & معامل الفا & \\
\hline $0.865-0.771$ & 0.824 & ثبات الاستبيان ككل \\
\hline
\end{tabular}




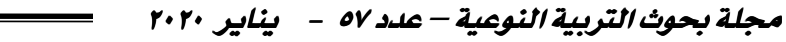

يتضح من الجدول السـابق أن جميع قيم معاملات الثبات : معامل الفا ، التجزئـة النصفية ،

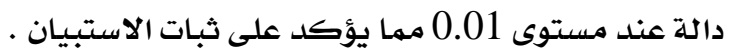

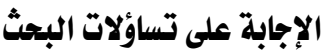

للإجابة على التساؤل الأول الذى ينص على "ما السمات المميزة للإيقاع وأنواعه كأحد

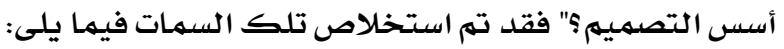

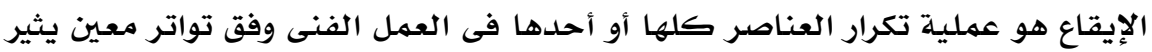

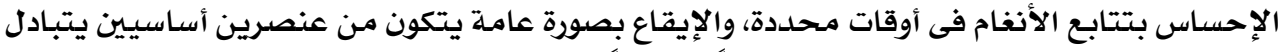

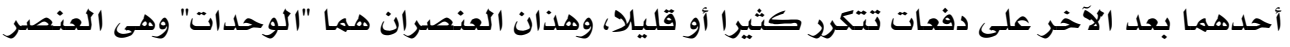

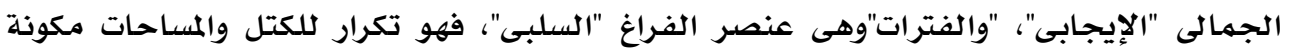

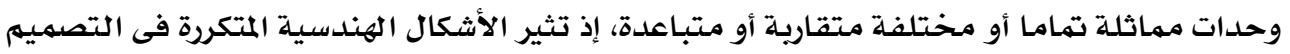

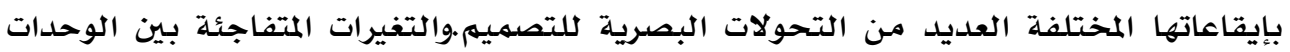

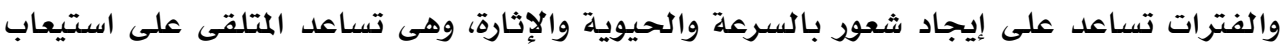

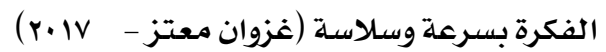

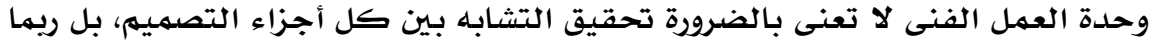

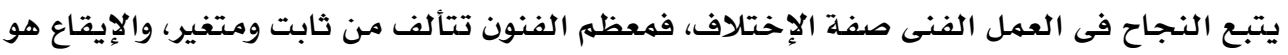

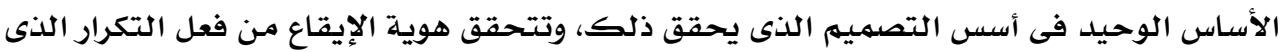

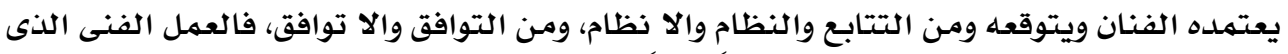

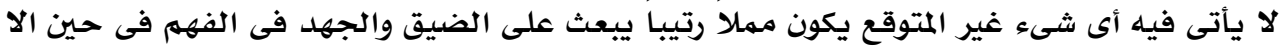

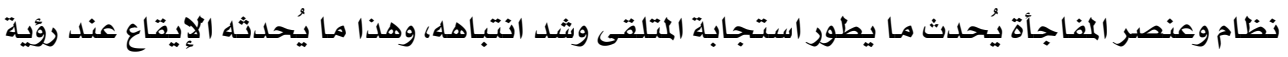

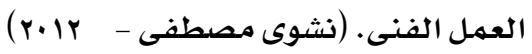
أنواع الإيقاع: ينقسم الإيقاع إلى إيقاع مسموع، وإيقاع مرئى.

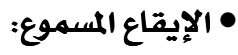

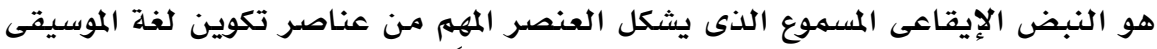

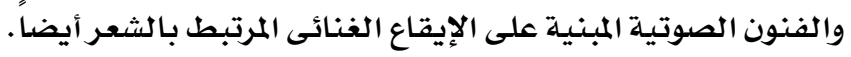

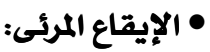

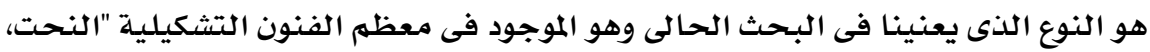

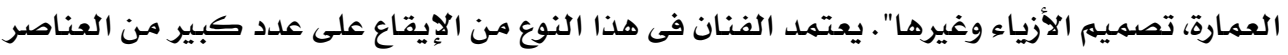

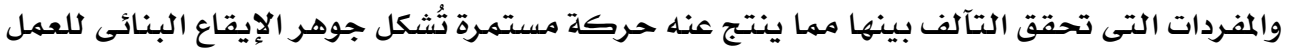

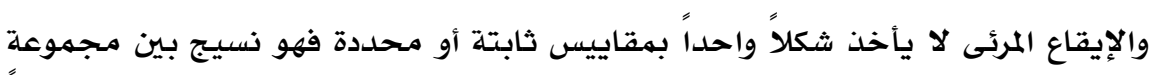

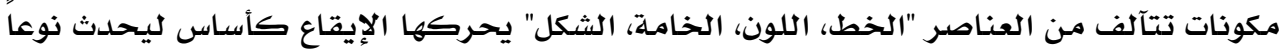


من العلاقات الجمالية التى تثرى العمل الفنى عند رؤيته. وينقسه الإيقاع المرئى إلى إيقاع خطى

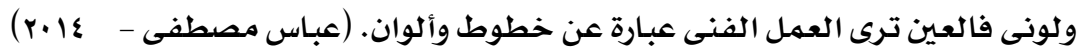

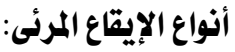
ا. الإيقاع الخطى: عبارة عن حركة الخطوط والمساحات مابين الوحدات والفترات فى العمل

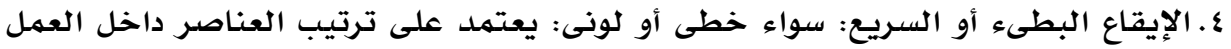

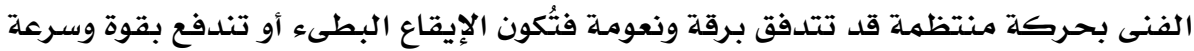

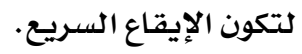

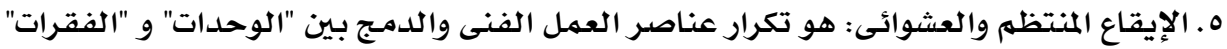

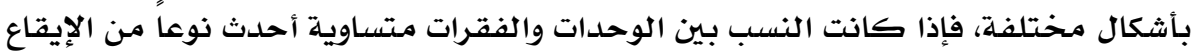
المنتظم، بينما إذا كانت النسب بين فاندان الوحدات والفقرات غير ثابتة وعشوائية نتج الإيقاع

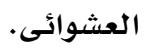

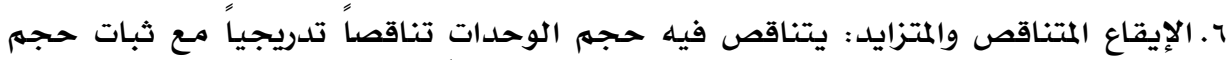

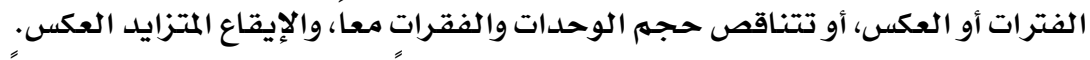

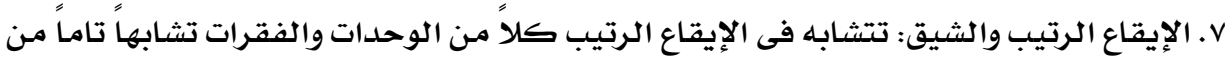

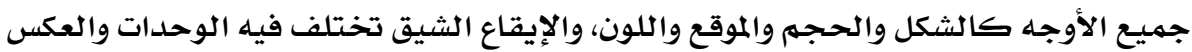

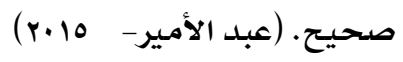

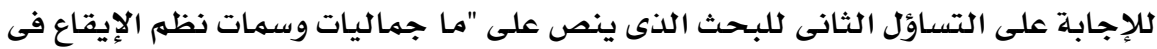

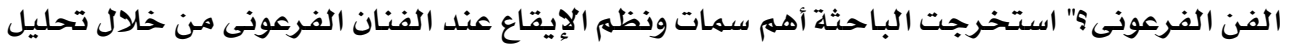

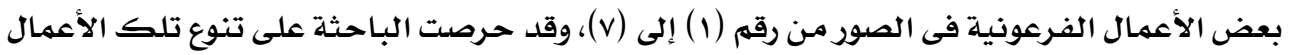

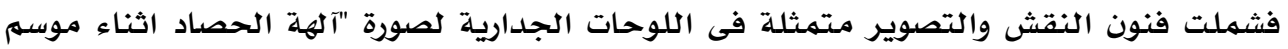

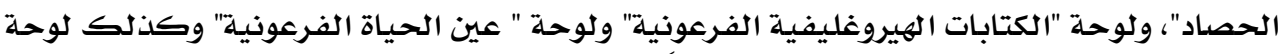

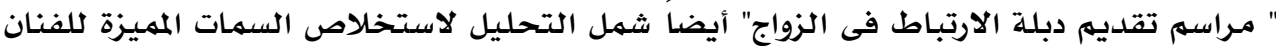

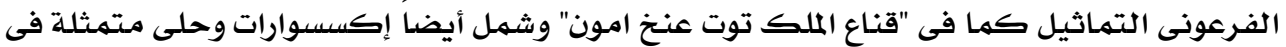

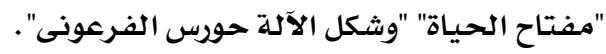

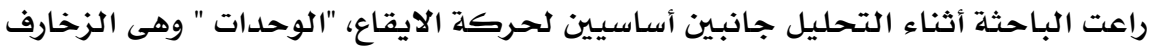

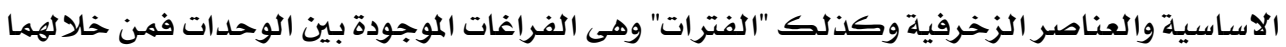

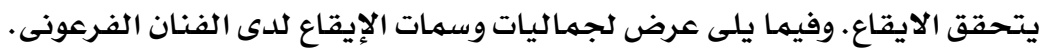


ا ـ الإيقاع فى لوحة " آلهة الحصاد اثناء موسم الحصاد":

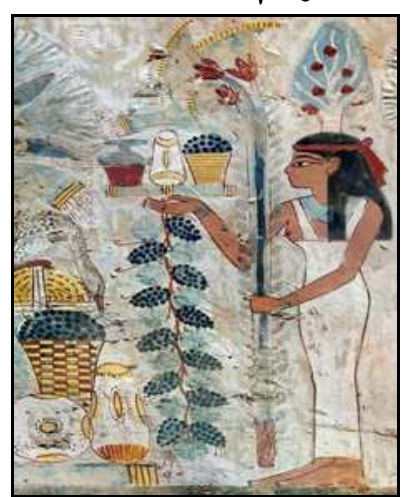

\section{لوحة (1) آلهة الحصاد اثناء موسم الحصاد}

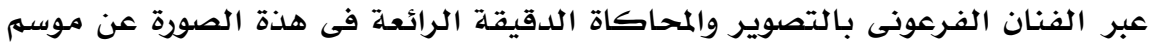

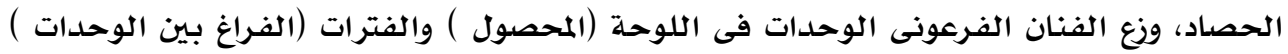

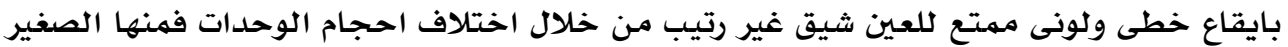

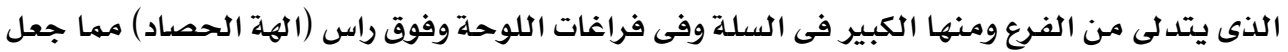

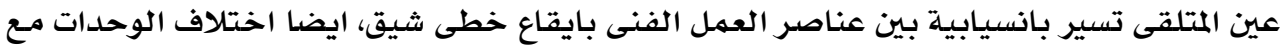

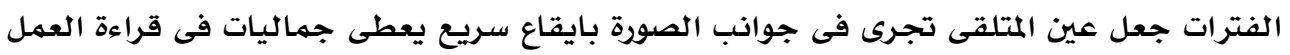

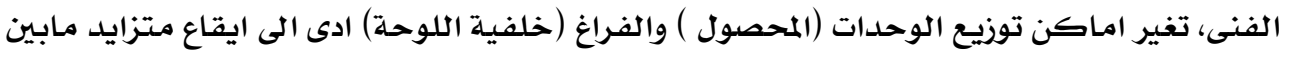

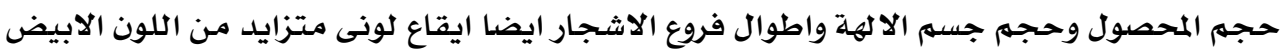

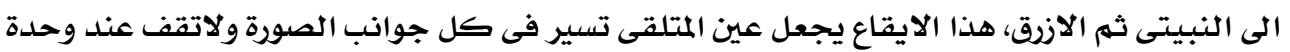

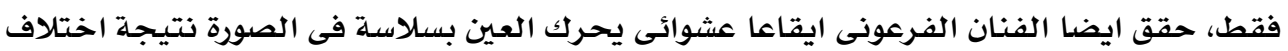

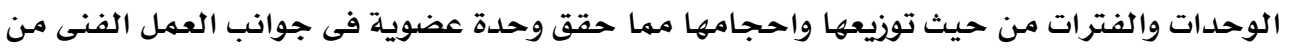

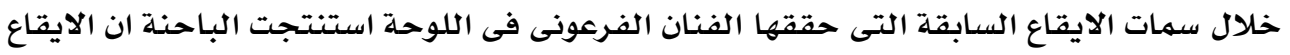

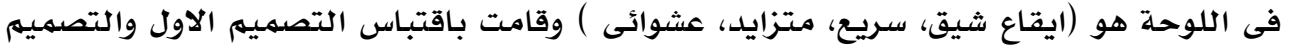
السـادس من تلك اللوحلة. 
r . الإيقاع فى اللوحة الجدارية للكتابات الهيروغلوفية:

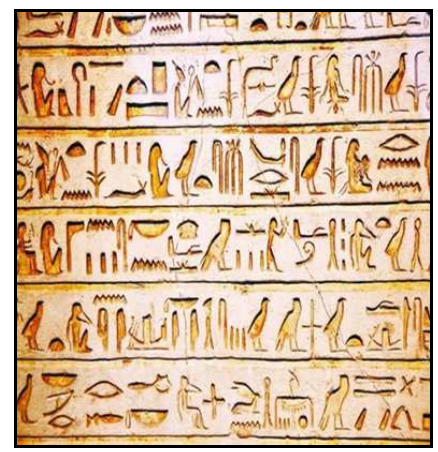

\section{لوحة (Y) لوحة الكتابات الهيروغليفية الفرعونية}

صورة توضح لوحة الكتابة الهيروغليفية التى اعدها الفنان الفرعونى ووضيح بداخلها

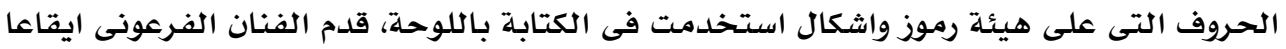

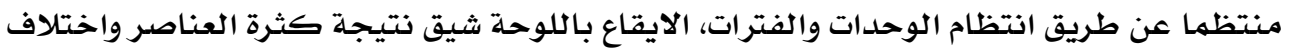

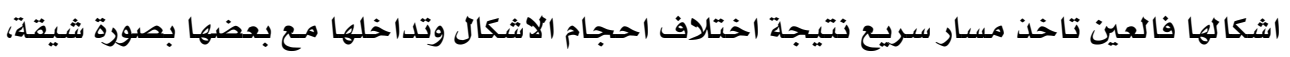

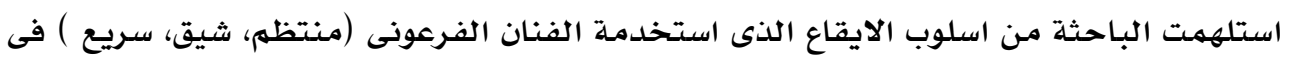

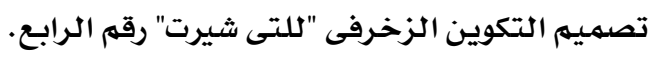
r. الإيقاع فى قناع الملك توت عنخ آمون:

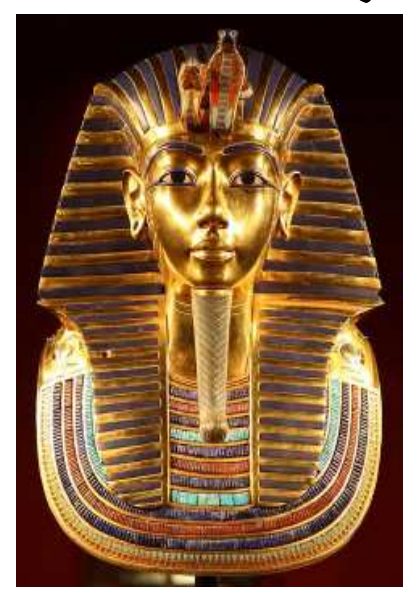

$$
\text { صورة (r) قناع الملك توت عنخ امون }
$$

صورة قناع الملك توت عنخ امون تعد مدرسة فنية للايقاع الخطى واللونى فهى تحمل قوة

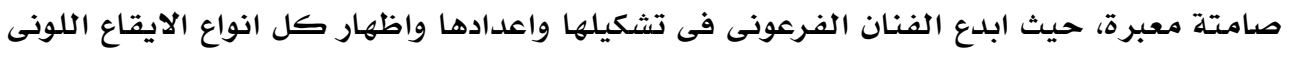

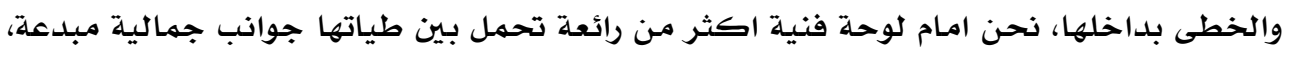


حيث تبعث الحيوية والديناميكية والطاقة الكامنة من هذا العمل الفنى، فاطلق الفنان الفرعونى

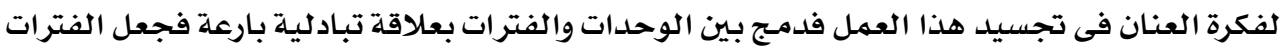

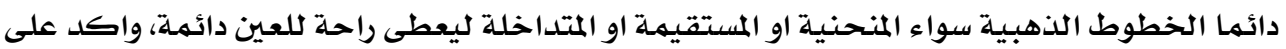

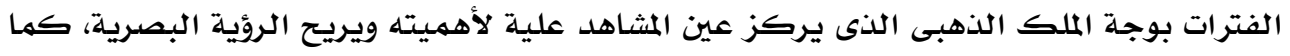

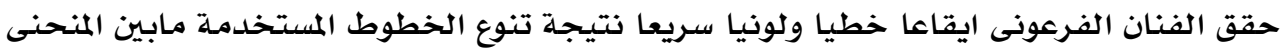

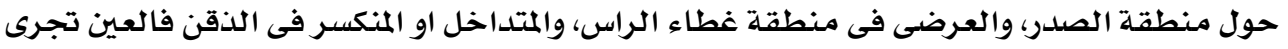

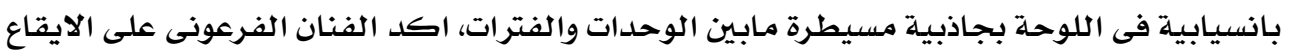

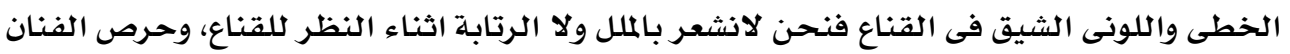

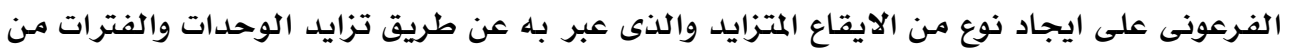

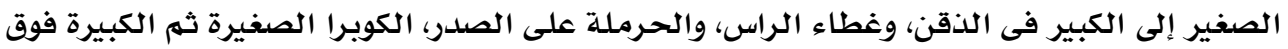

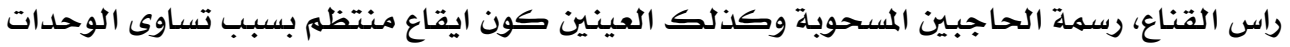

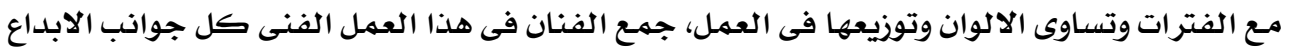

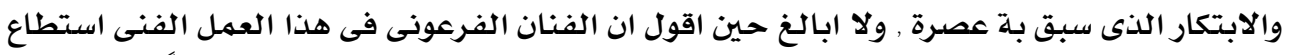

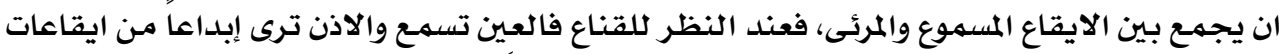

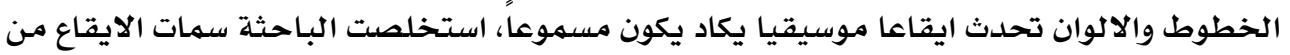

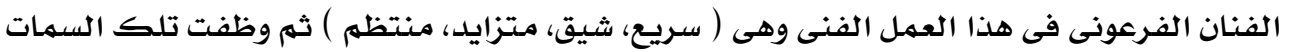
فى اقتباس التصميم الثامن. ع. الإيقاع فى مفتاح الحياة:

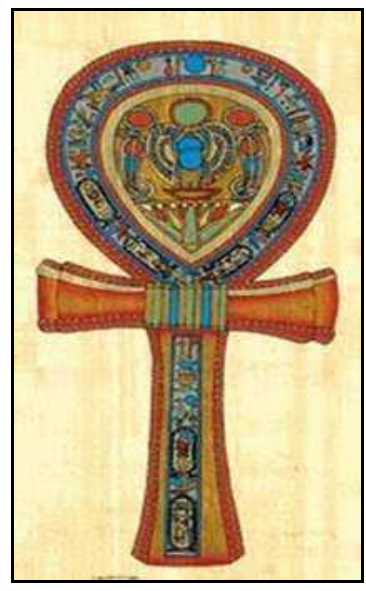

$$
\text { صورة (ع) مفتاح الحياة }
$$

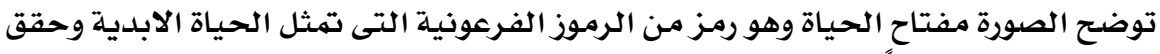

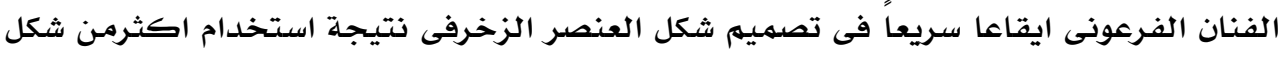

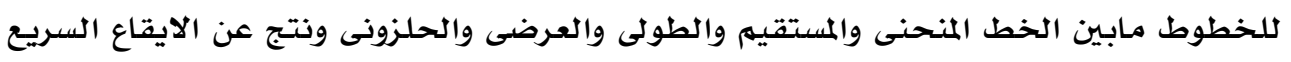


حركة سريعة لمسار العين للمتذوق الفنى عند النظر للعنصر الزخرفى، الايقاع السريع الذى ابدعة

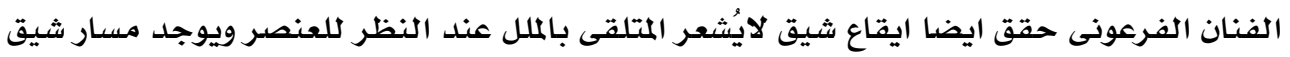

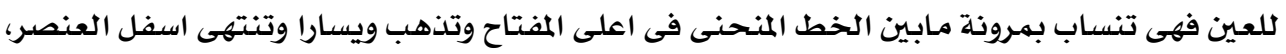

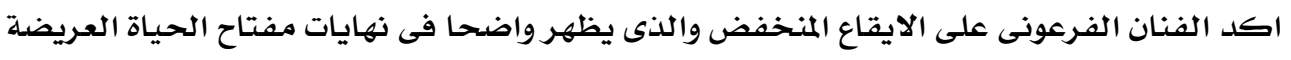

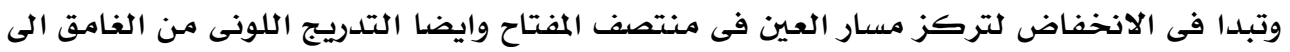

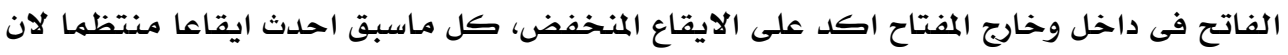

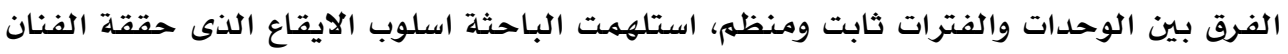

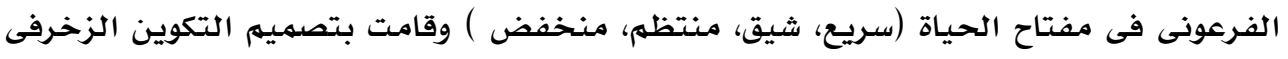

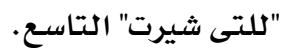
ه. الإيقاع فى الإله حورس:

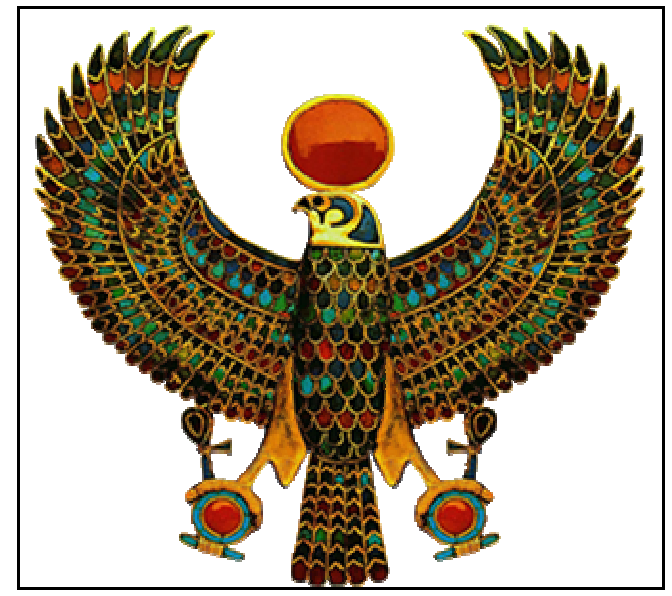

صورة (0) شكل الالة حورس الفرعونى

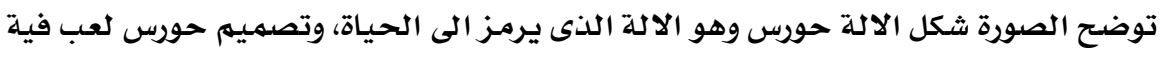

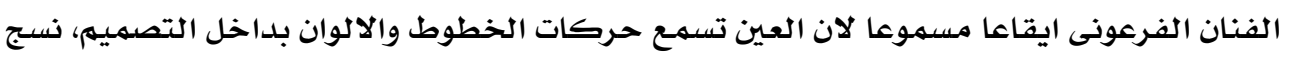

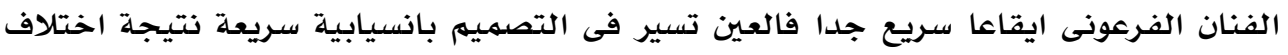

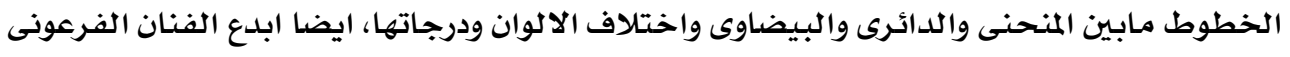

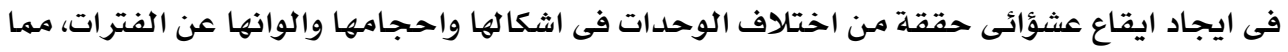

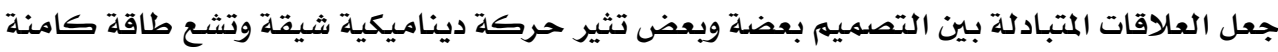

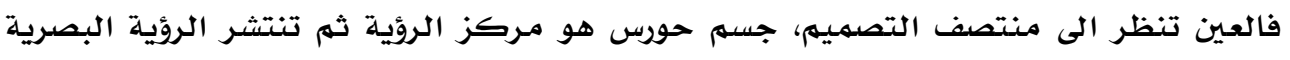

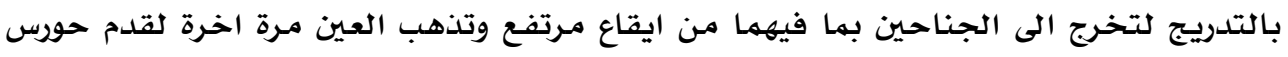

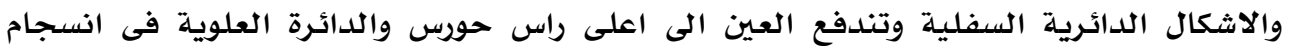

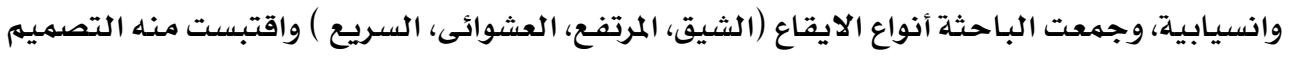


7. الإيقاع فى عين الحياة:

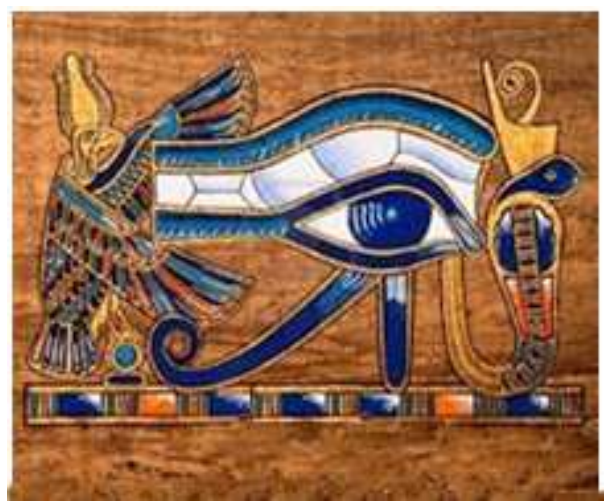

صورة (7) عين الحياة الفرعونية

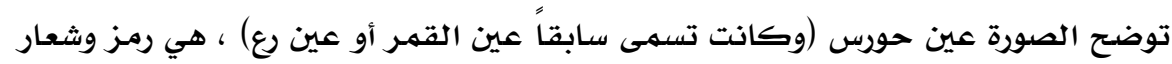

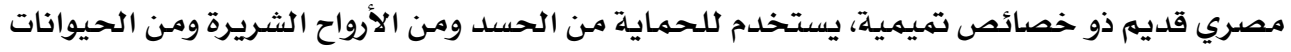

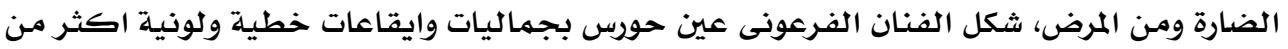

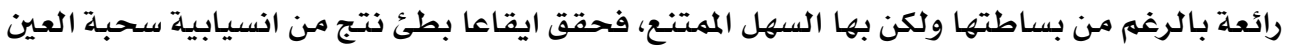

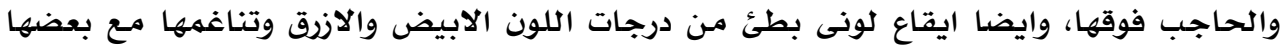

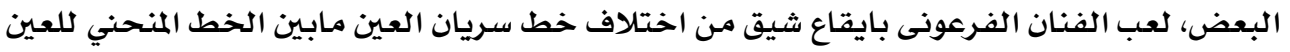

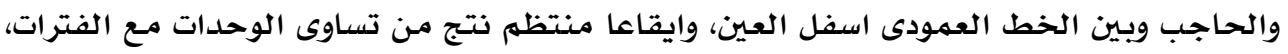

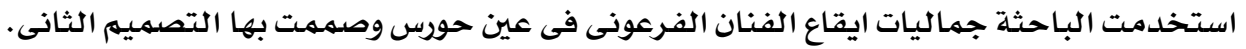
v . الإيقاع فى لوحة مراسم تقديم دبلة الارتباط فى الزواج:

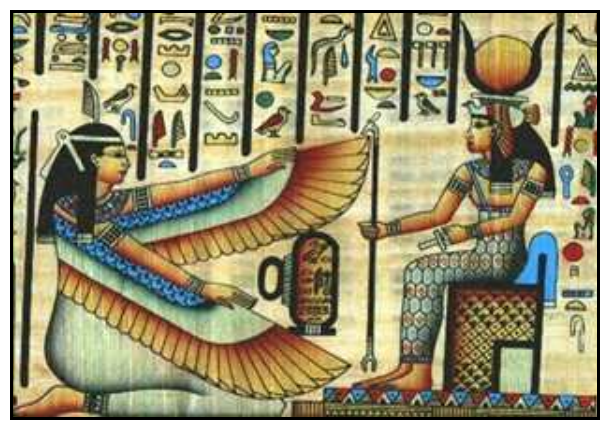

$$
\text { لوحة (v) مراسم تقديم دبلة الارتباط فى الزواج }
$$

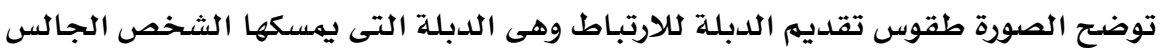

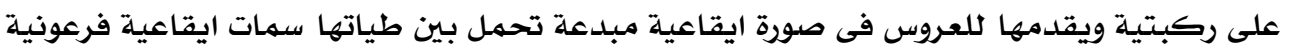

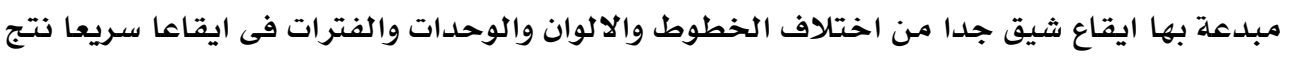


من سرعة سريان العين مابين حجم الوحدات للشخصتين وبين الفترات وهى الخلفية بما تحملة من

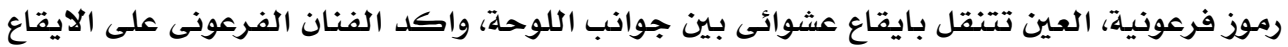

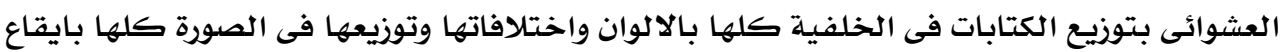

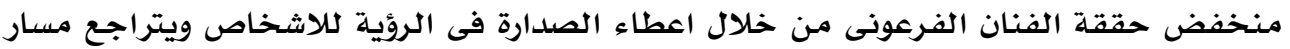

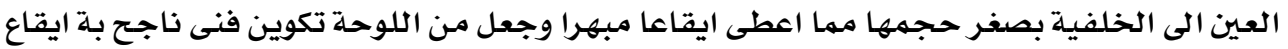

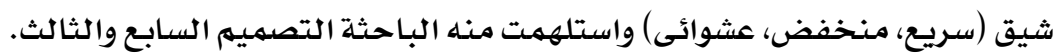
للإجابة على التساؤل الثالث الذى ينص على: "ما إمكانية الإستفادة من تحليل نظم

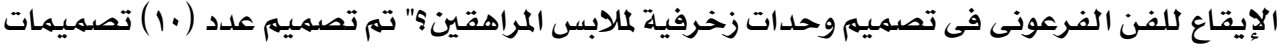

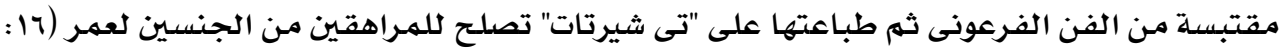

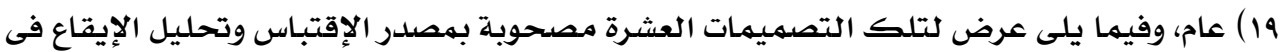
كل تصميهم. التصمييم الاول

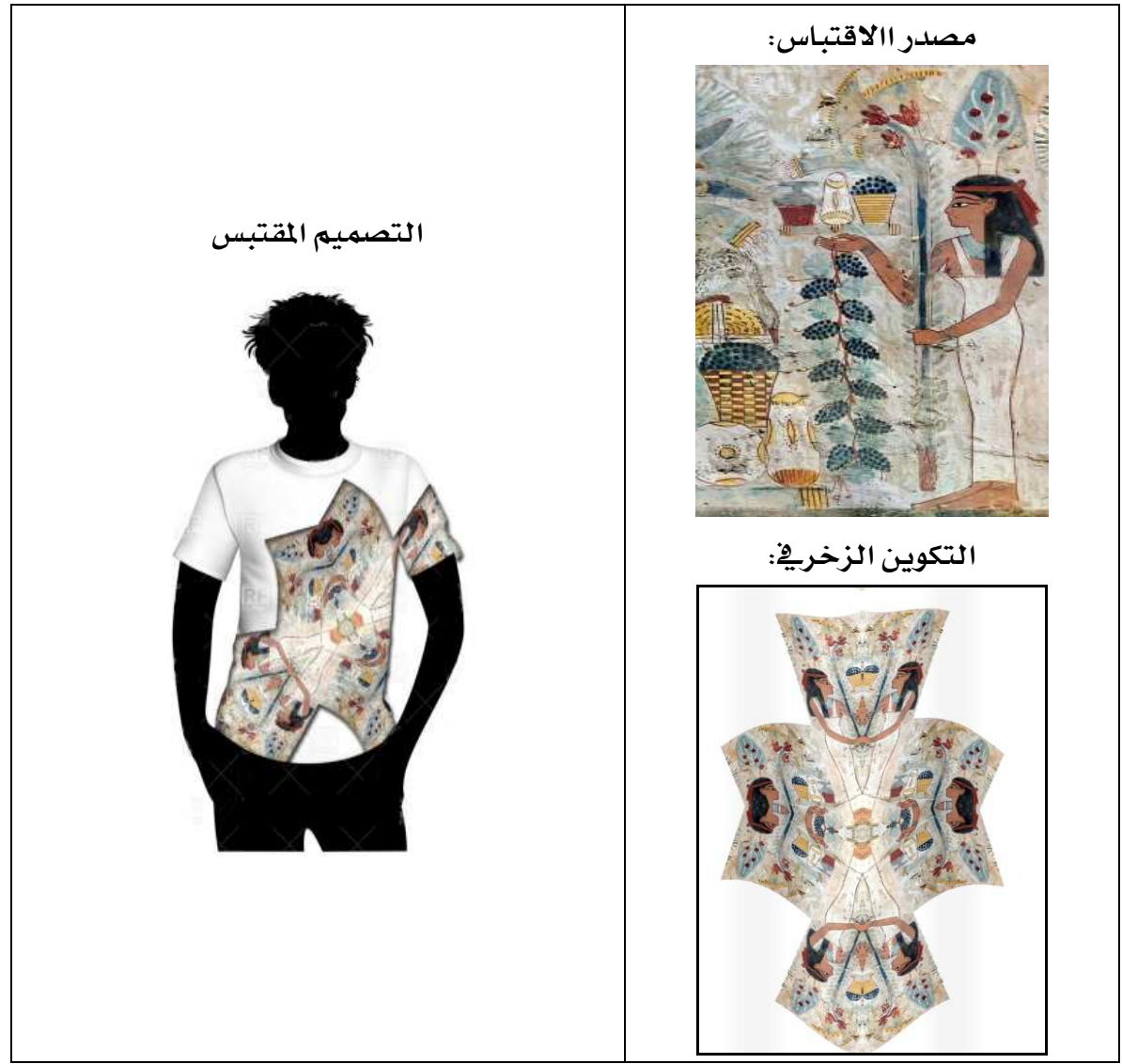


تحليل التصميم :

استلهمت الباحثة اسلوب الايقاع الذى اتبعة الفنان الفرعونى فى لوحة الحصاد (ايقاع شيق, سـريع ,مـتزايد , عشوائى) واقنبست منـة تصهيم الطباعة على التى شيرت وحرصت على تحقيق نفس اساليب الايقاع فيظهر الايقاع الشيق والسريع فى طريقة توزيع تصميم الطباعة على الكم بجانب وضعة على الصدر بحيث تتخذ العين مسار سريـع وشيق , بينها الايقاع المتزايد تحقق فى كبر حجم تصديهم الطباعة على الصلدر عن التصميهم عن الكم فى تدريج متزايد والايقاع العشوائى فى اختلاف احجام واشكال الوحدات والفترات فحرصت الباحثة على توزيـع التصهيم الطباعى باسلوب يجعل الرؤية البصرية تتجهة بهسار عشوائى بين الفترات والوحدات عبر تصميهم الطباعة التصميي الثانى

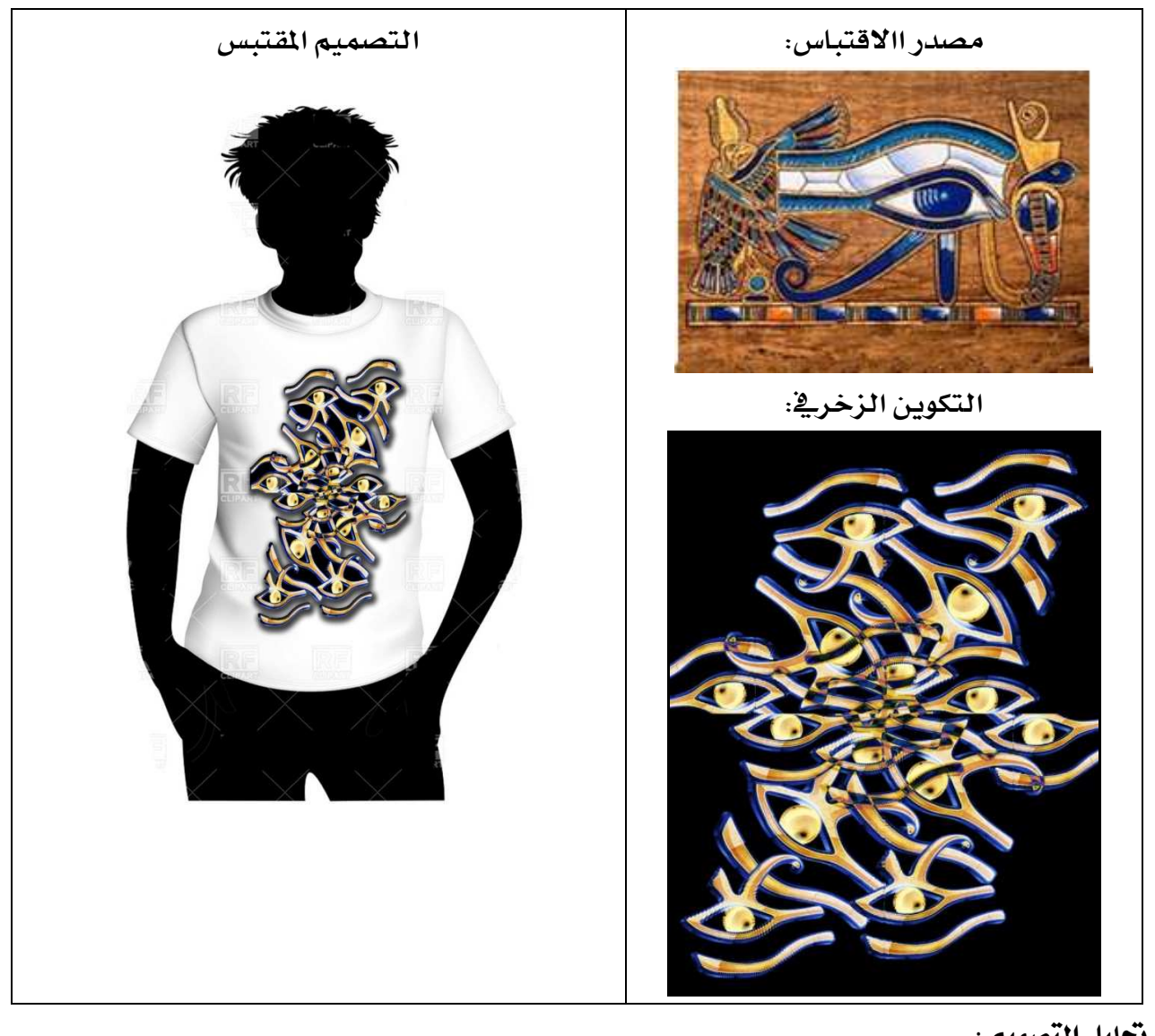

تحليل التصميه :

استلهمت الباحثة اسلوب الايقاع الذى اتبعة الفنان الفرعونى فى عين الحياة (ايقاع شيق.

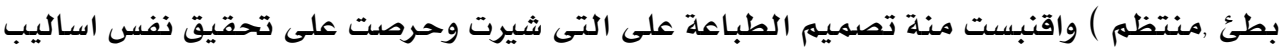




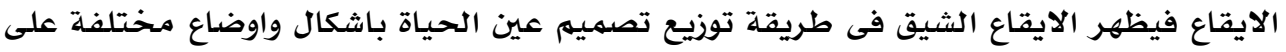

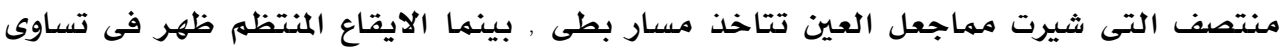

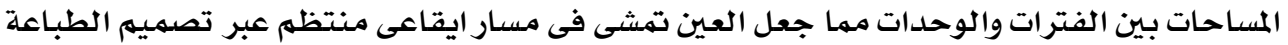
على الى شيرت التصميه الثالث

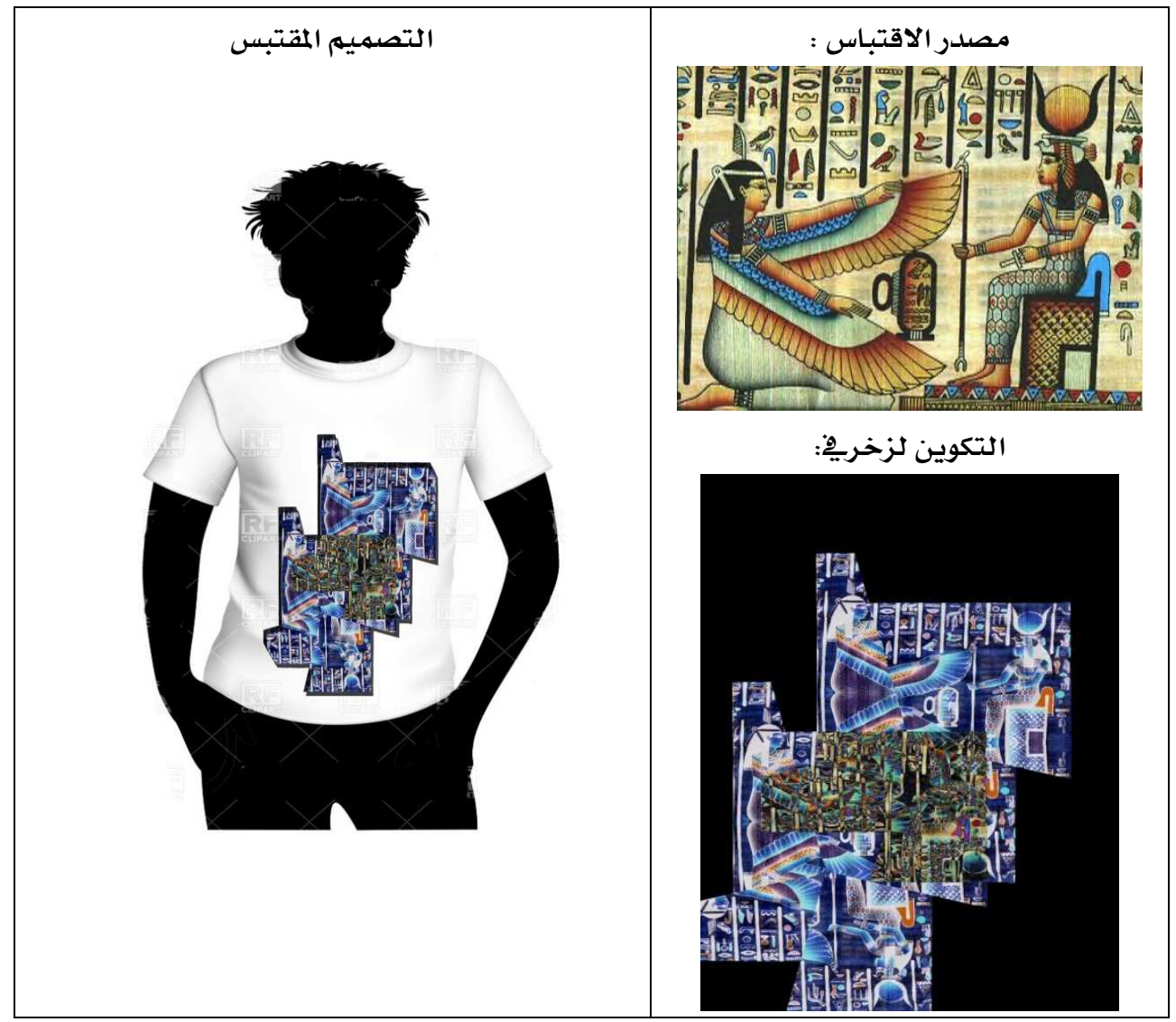

تحليل التصميه :

استلهمت الباحثة اسلوب الايقاع الذى اتبعة الفنان الفرعونى فى لوحة تقديم الدبلة

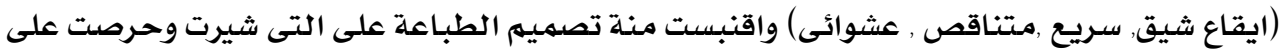

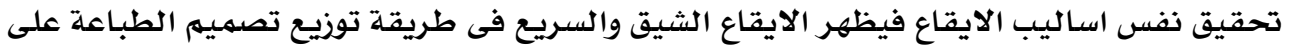

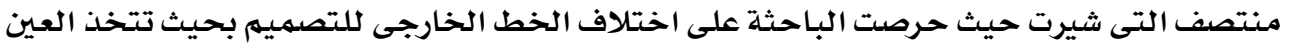

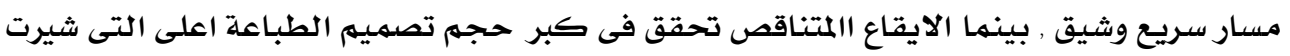




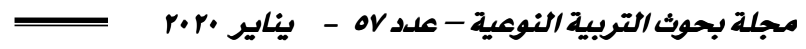

وتراجع وتناقص الرؤية البصرية فى نهايتة والايقاع العشوائى فى عشؤائية حركة العين مابين

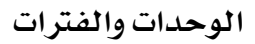

التصميه الالرابع

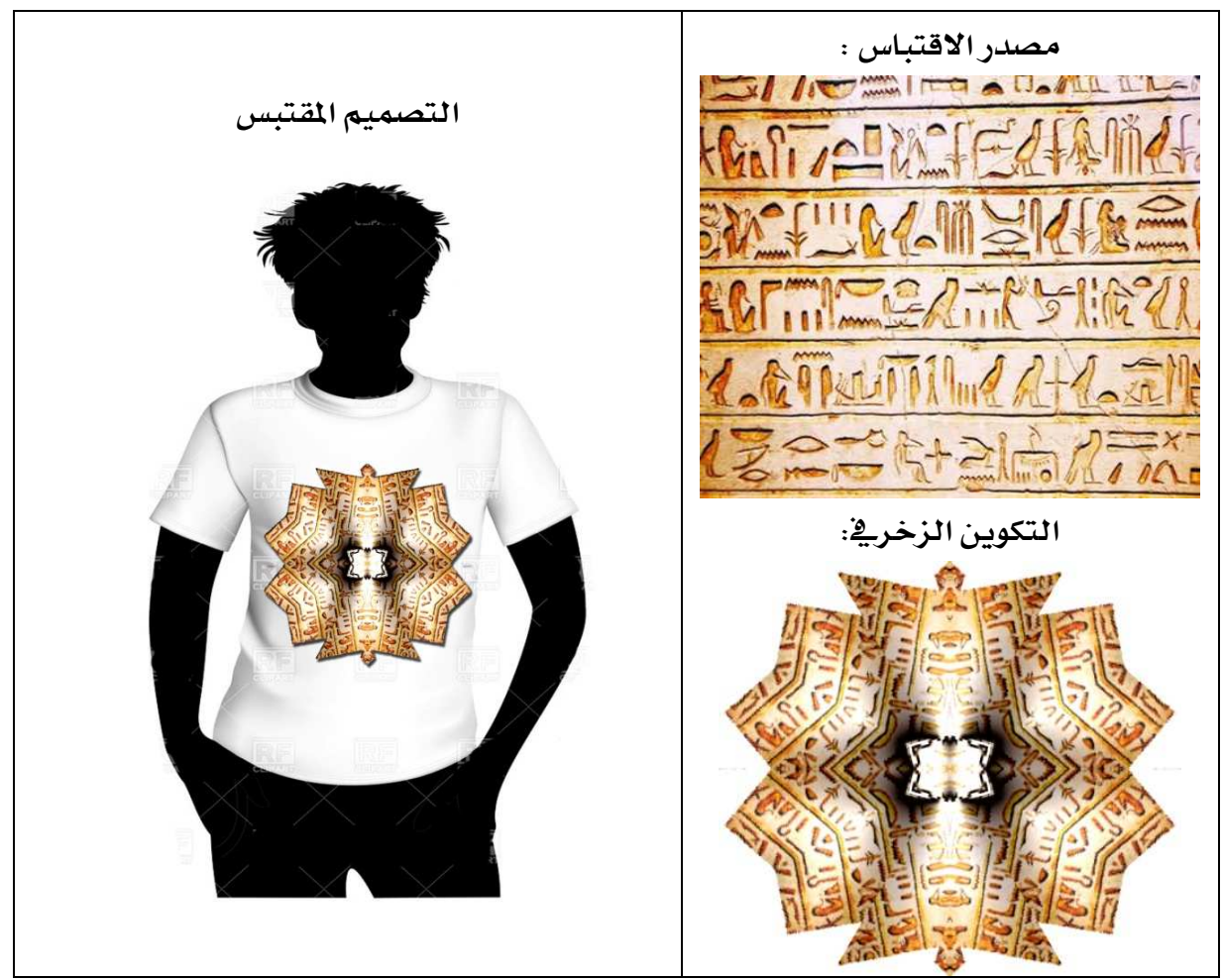

تحليل التصميه :

استلهمت الباحثة اسلوب الايقاع الذى اتبعة الفنان الفرعونى فى لوحة الكتابات

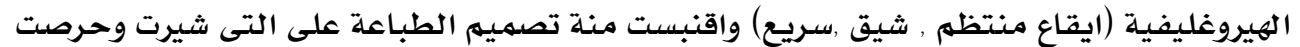

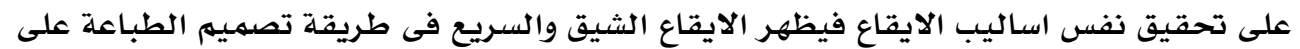

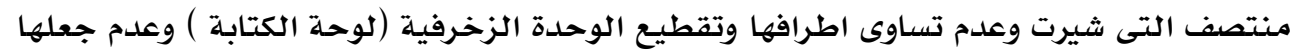

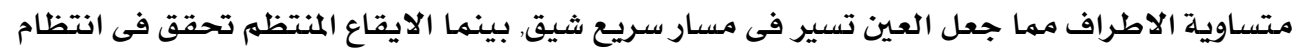
توزيع الوحدات مـع الفترات 


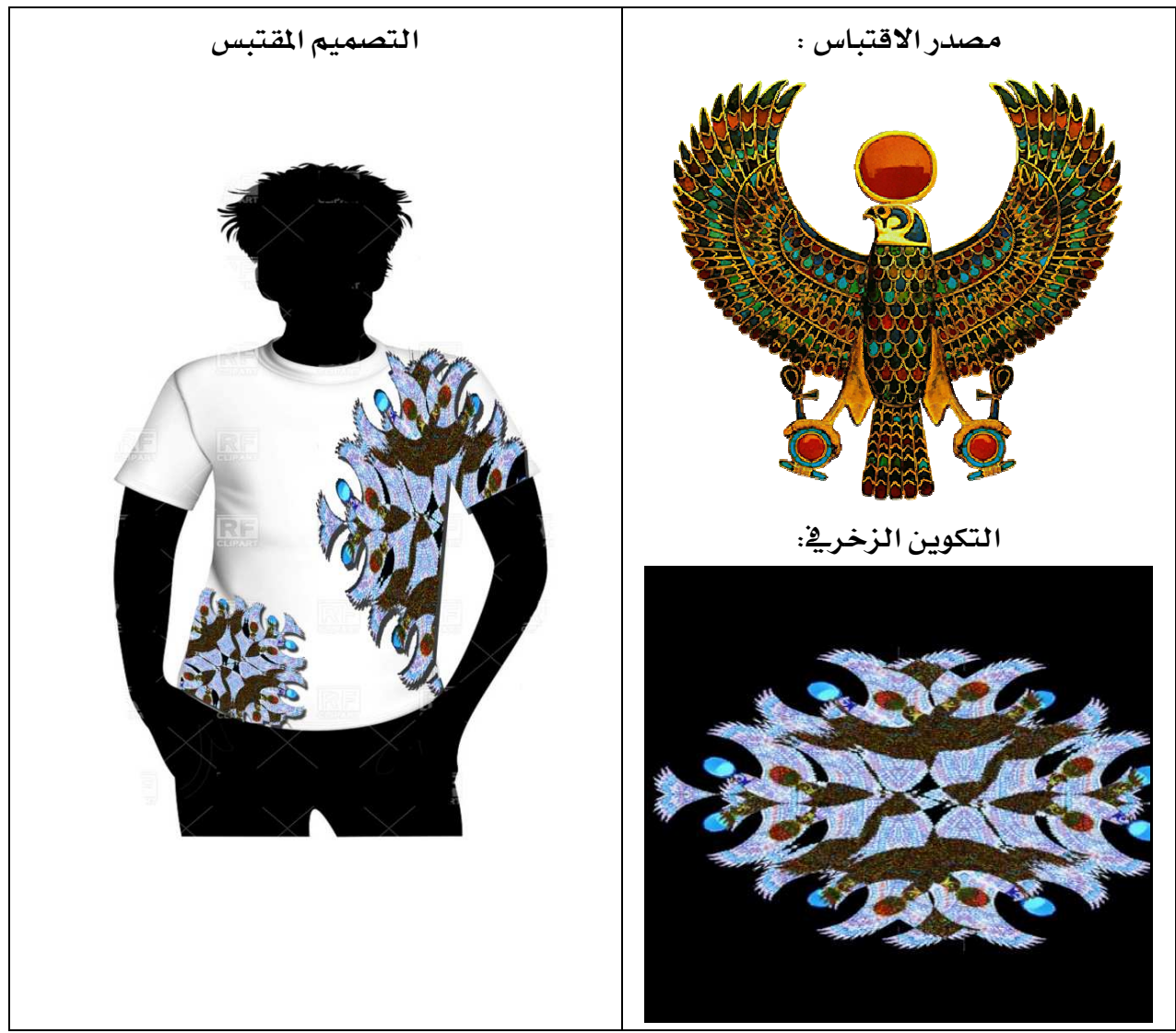

تحليل التصميي :

استلهمت الباحثة اسلوب الايقاع الذى اتبعة الفنان الفرعونى فى رمز حورس (ايقاع شيق.

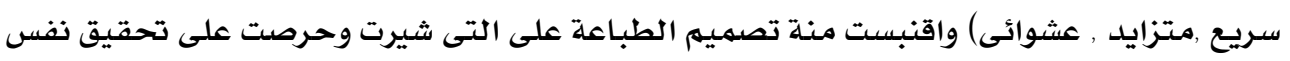

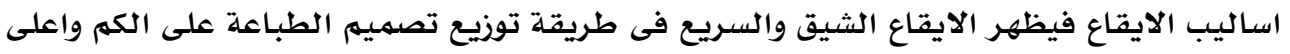

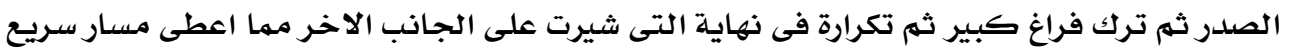

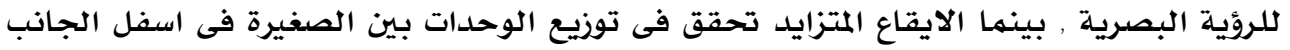

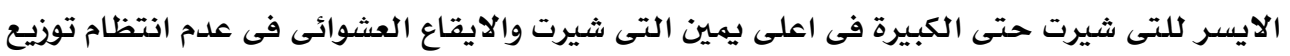

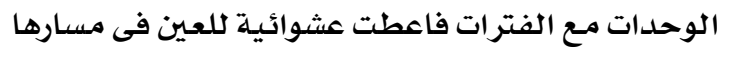


التصميه السادس

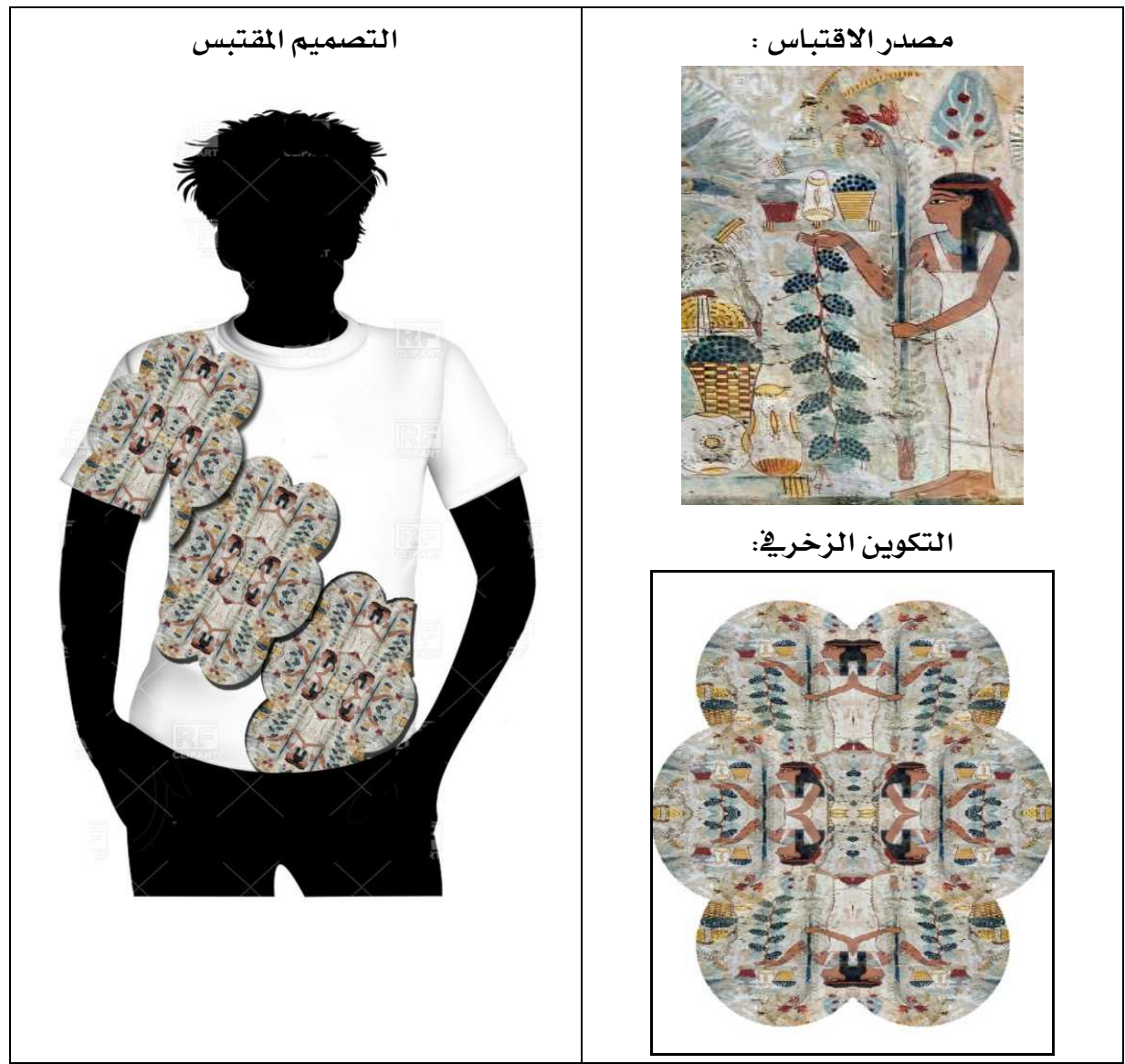

تحليل التصميه :

استلهمت الباحثة اسلوب الايقاع الذى اتبعة الفنان الفرعونى فى لوحة الحصاد (ايقاع

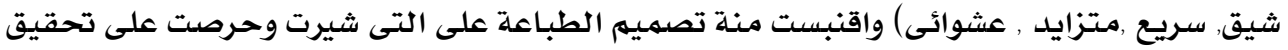

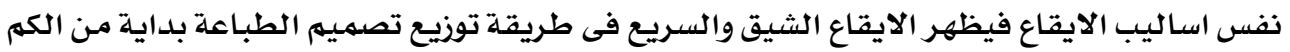

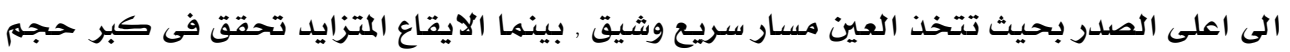

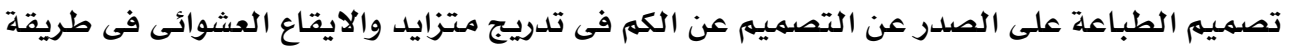

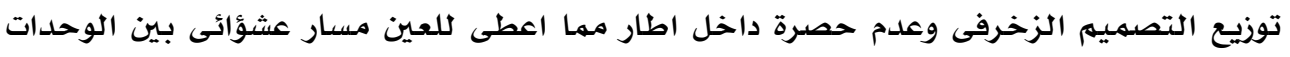
والفترات عبر التصميهم التهيم الترخرفي 
التصميم السابع

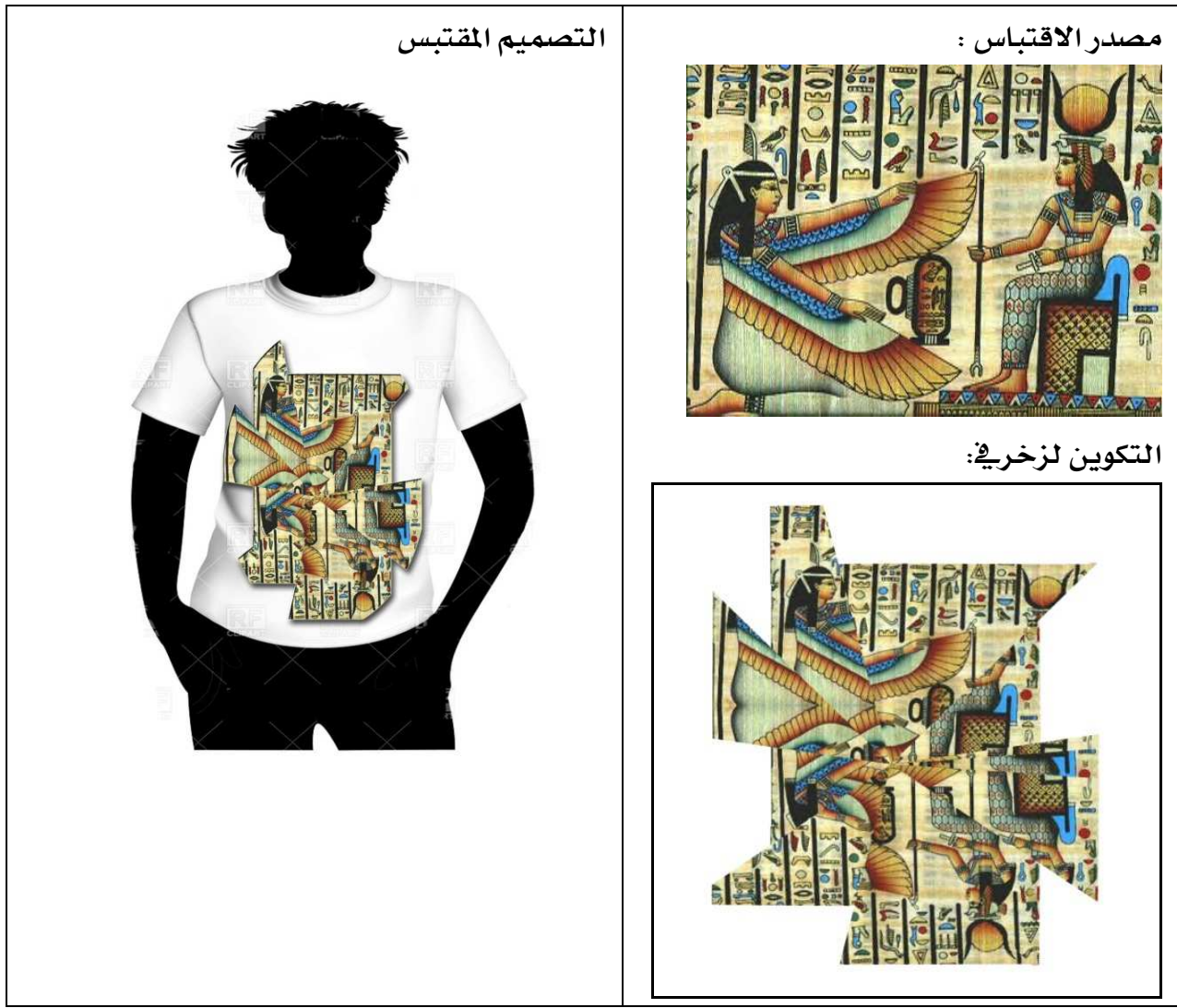

تحليل التصميم :

استلهمت الباحثة اسلوب الايقاع الذى اتبعة الفنان الفرعونى فى لوحة تقديم الدبلة

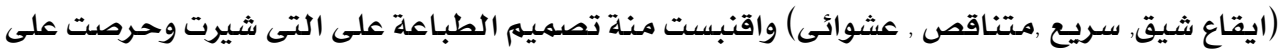

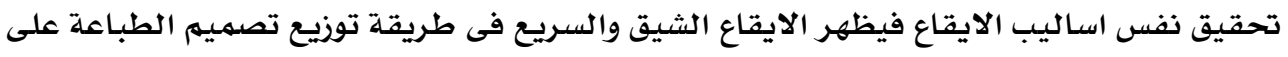

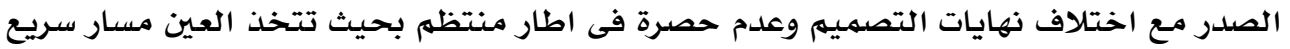

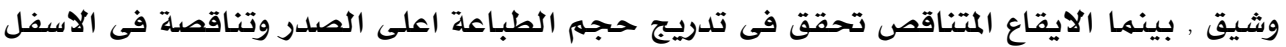

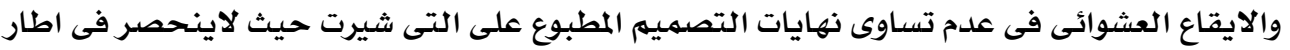

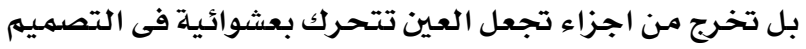



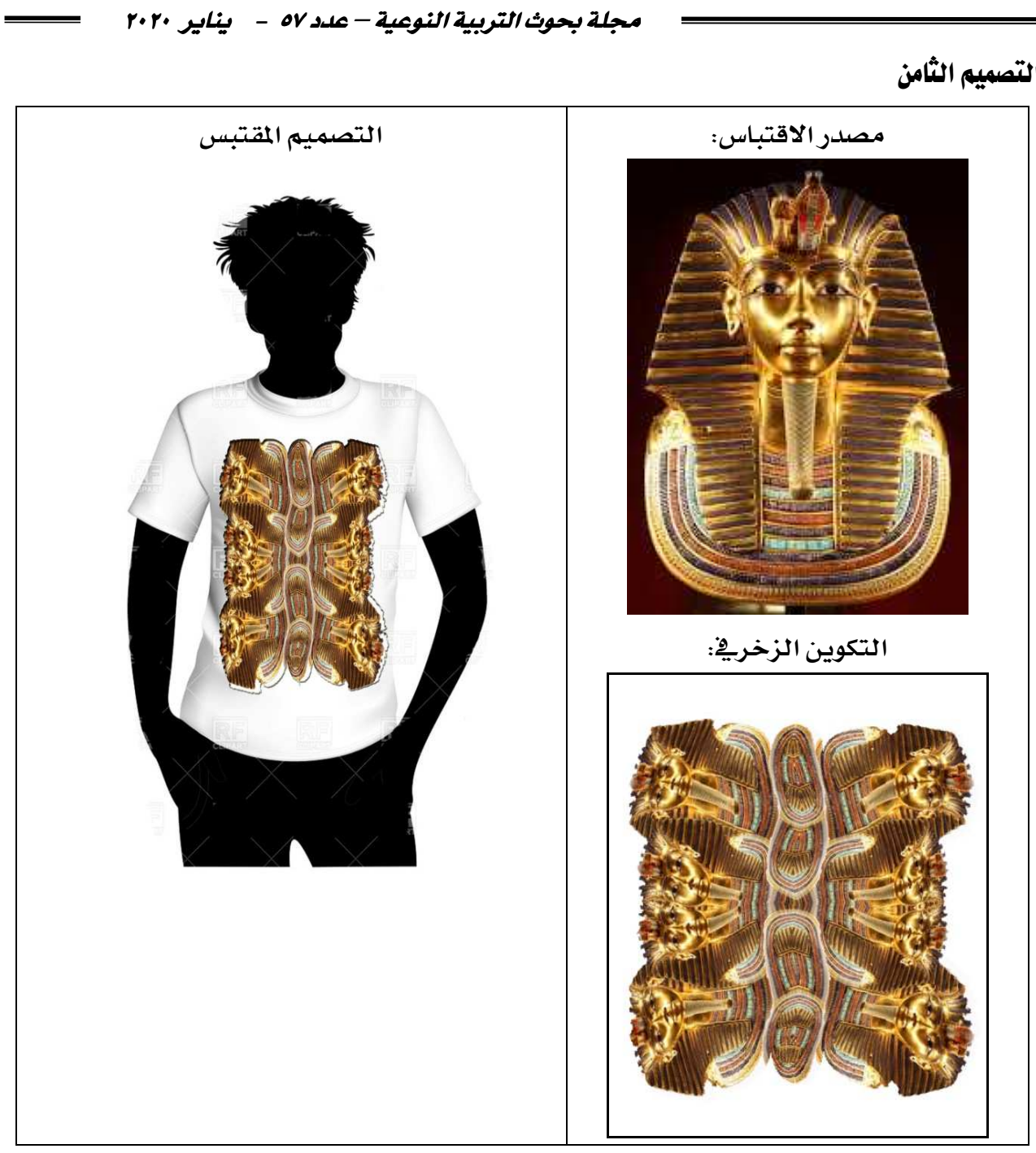

تحليل التصميه :

استلهمت الباحثة اسلوب الايقاع الذى اتبعة الفنان الفرعونى في قناع الملك توت عنتخ امون

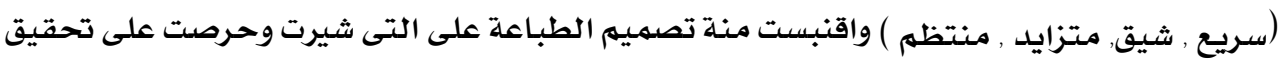

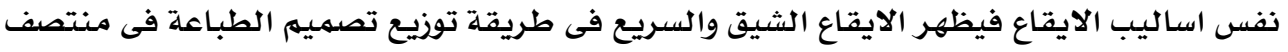

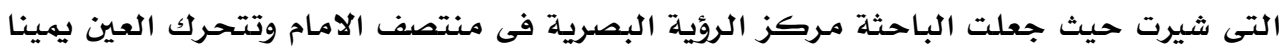

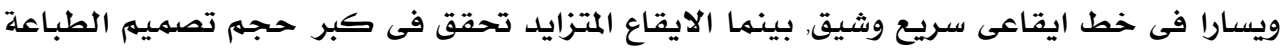

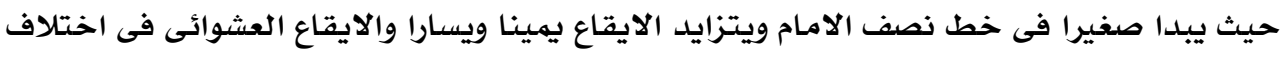
احجام الوحدات و الفترات فاعطت عشوائية للعين في مسارها 
التصميي التاسع

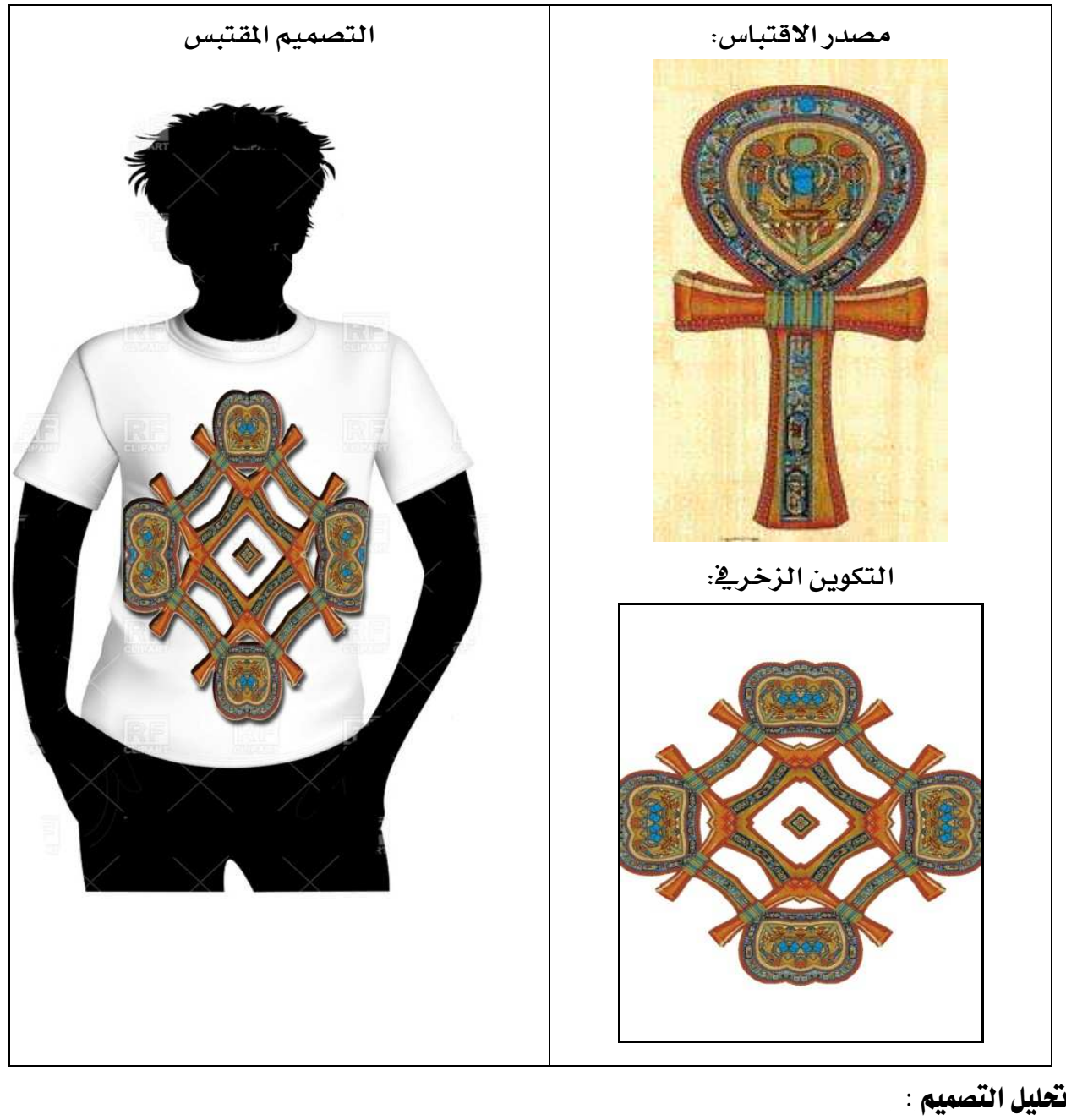

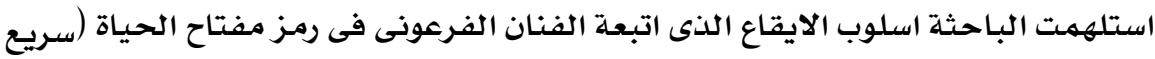

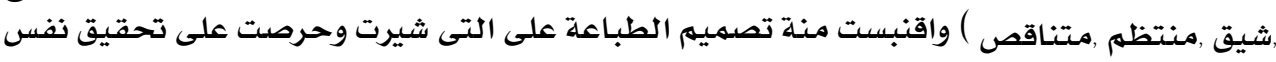

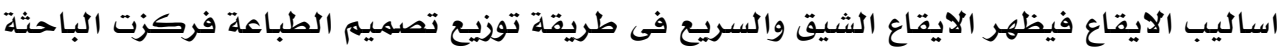

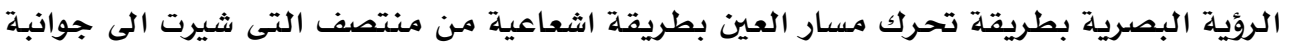

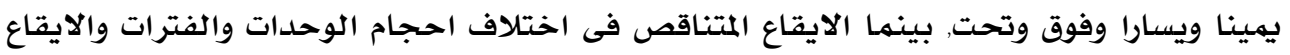

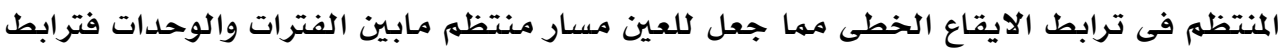

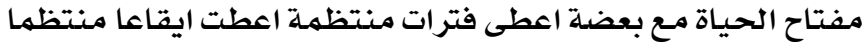




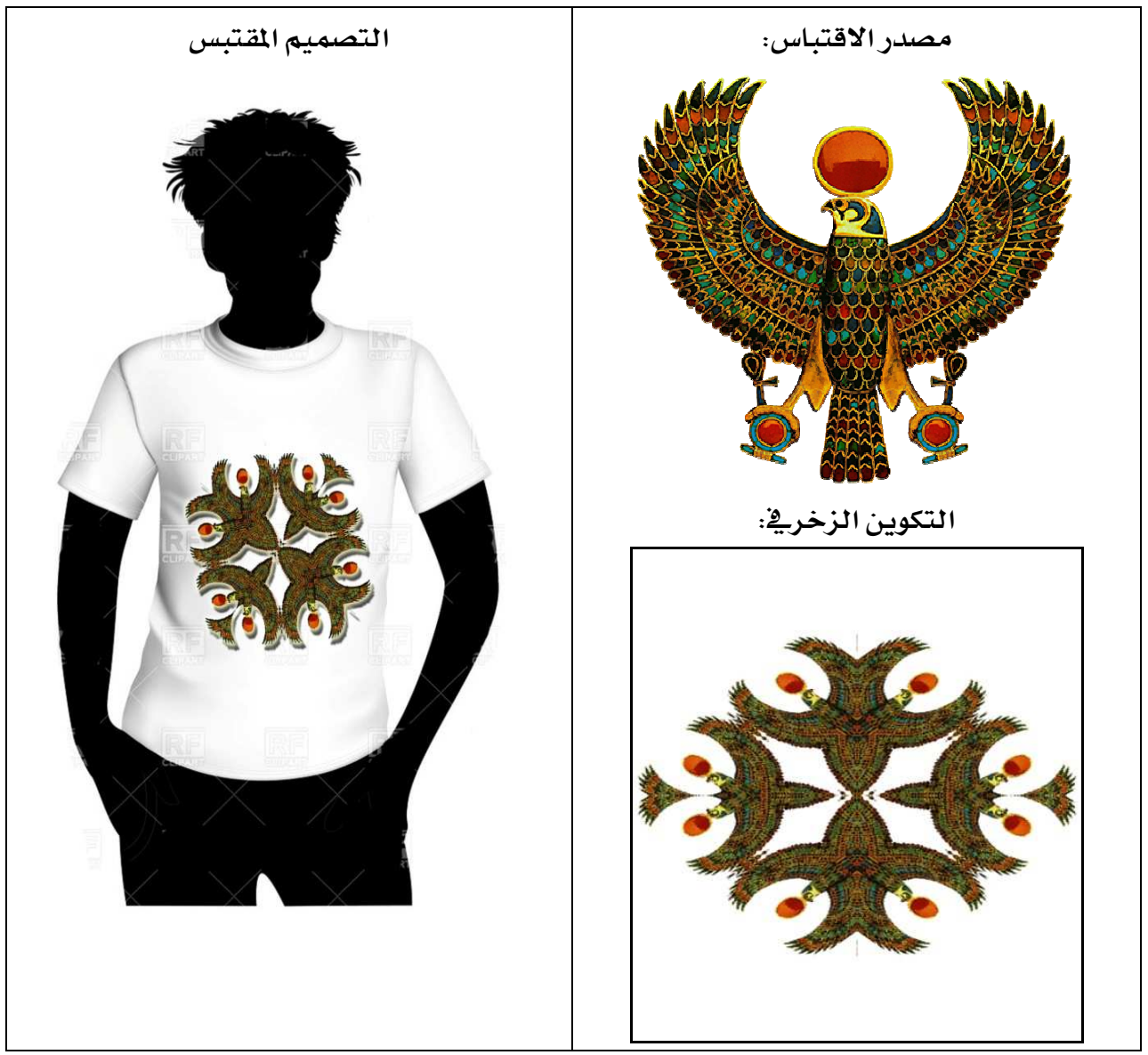

تحليل التصميي :

استلهمت الباحثة اسلوب الايقاع الذى اتبعة الفنان الفرعونى فى رمزز حورس (ايقاع شيق.

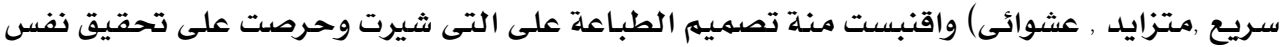

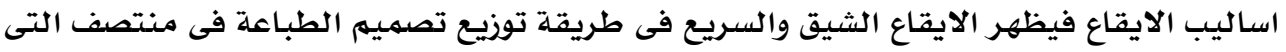

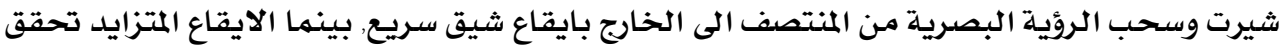

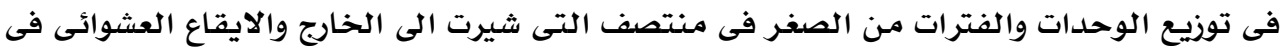

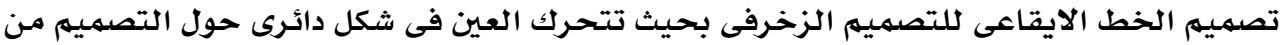

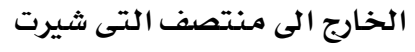


للإجابة على التساؤل الرابع الذى ينص على "ما آراء المتخصصين فى الأزياء تجاه

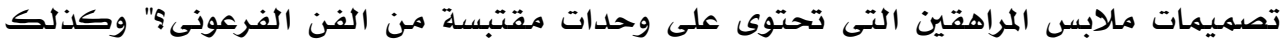

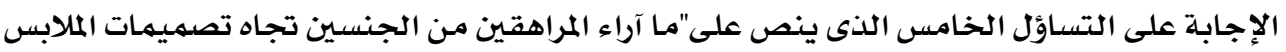

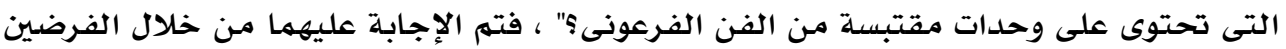

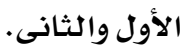
الثرض الأول : الأول

ينص الفرض الأول على أنه "توجد فروق ذات دلالة إحصائية بين التصميمات العشر هِ

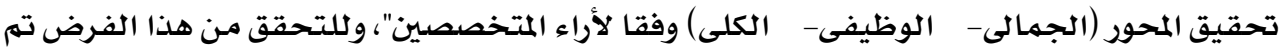

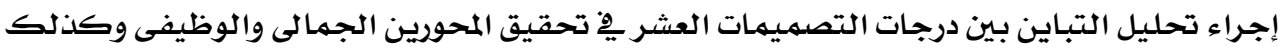

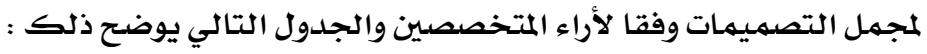

جدول (ه) تحليل التباين لدرجات مجمل التصميمات يِ تحقيق

المحور الجمالى والوظيفى والكلى وفقا لأراء المتخصصين

\begin{tabular}{|c|c|c|c|c|c|c|}
\hline الدلالة & قيمة (ف) & درجات الحرية & متوسط المربعات & مجموع المربعات & التباين & المحور \\
\hline \multirow{3}{*}{$\begin{array}{c}0.01 \\
\text { داJ }\end{array}$} & 32.618 & 9 & 564.583 & 5081.251 & بين المجموعات & \multirow{3}{*}{ الجمالى } \\
\hline & & 100 & 17.309 & 1730.894 & داخل المجموعات & \\
\hline & & 109 & & 6812.145 & المجموع & \\
\hline \multirow{3}{*}{$\begin{array}{c}0.01 \\
\text { داJ }\end{array}$} & 50.945 & 9 & 938.849 & 8449.640 & بين المجموعات & \multirow{3}{*}{ الوظيفى } \\
\hline & & 100 & 18.429 & 1842.884 & داخل المجموعات & \\
\hline & & 109 & & 10292.524 & المجموع & \\
\hline \multirow{3}{*}{ دال 0.01} & 40.663 & 9 & 864.233 & 7778.098 & بين المجموعات & \multirow{3}{*}{ الكلى } \\
\hline & & 100 & 21.254 & 2125.350 & داخل المجموعات & \\
\hline & & 109 & & 9903.448 & المجموع & \\
\hline
\end{tabular}

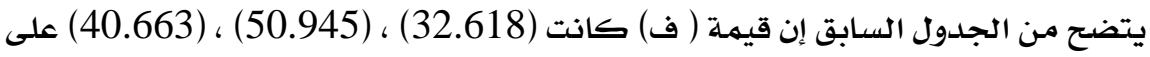

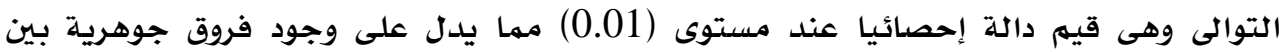

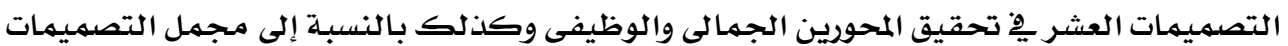

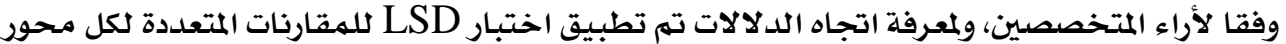

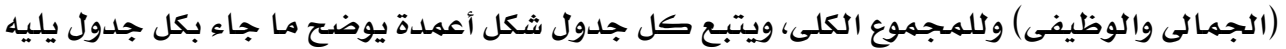

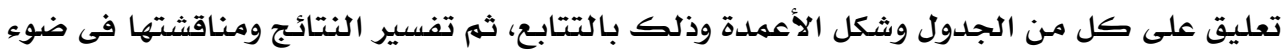

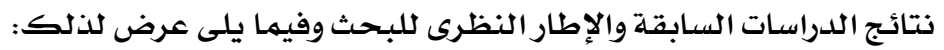




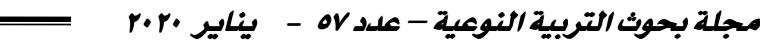

جدول ( ج ) اختبار LSD للمقارنات المتعددة للمحور الجمالى

\begin{tabular}{|c|c|c|c|c|c|c|c|c|c|c|}
\hline "التصميم "• = 11.354" & التصميه "9" = 24.298 " & م = التصميم" 14.354 & 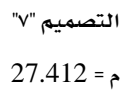 & التصميم "ז" & التصميه "ه" & التصميه "؟ = 32.572 & التصميم "r" & التصميه "ץ" & التصميم "I" & التصميم \\
\hline & & & & & & & & & - & التصميم "ا" \\
\hline & & & & & & & & - & $* * 13.323$ & التصميم "ץ" \\
\hline & & & & & & & - & $* * 12.614$ & 0.709 & التصميه "r" \\
\hline & & & & & & - & $* * 10.545$ & $* 2.069$ & $* * 11.254$ & التصميم "§" \\
\hline & & & & & - & **14.990 & $* * 4.445$ & $* * 17.060$ & **3.736 & التصميم "ه" \\
\hline & & & & - & $* * 9.763$ & $* * 24.754$ & $* * 14.209$ & $* * 26.823$ & $* * 13.500$ & التصميم "ף" \\
\hline & & & - & $* * 19.594$ & $* * 9.830$ & $* * 5.160$ & $* * 5.385$ & $* * 7.229$ & $* * 6.094$ & "V" التصميم \\
\hline & & - & **13.058 & $* * 6.536$ & $* * 3.227$ & $* * 18.218$ & $* * 7.672$ & $* * 20.287$ & $* * 6.963$ & التصميم "ᄉ" \\
\hline & - & $* * 9.943$ & $* * 3.114$ & $* * 16.480$ & $* * 6.716$ & $* * 8.274$ & $* 2.270$ & $* * 10.343$ & $* 2.980$ & التصميم "ه" \\
\hline - & $* * 12.943$ & $* * 3.000$ & $* * 16.058$ & $* * 3.536$ & $* * 6.227$ & $* * 21.218$ & $* * 10.672$ & $* * 23.287$ & $* * 9.963$ & التصميم "•1" \\
\hline
\end{tabular}

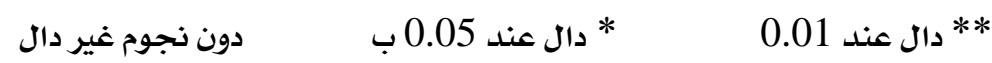

وفيما يلى شكل للأعمدة الذى يؤكد على النتيجة الواردة بالجدول السابق.

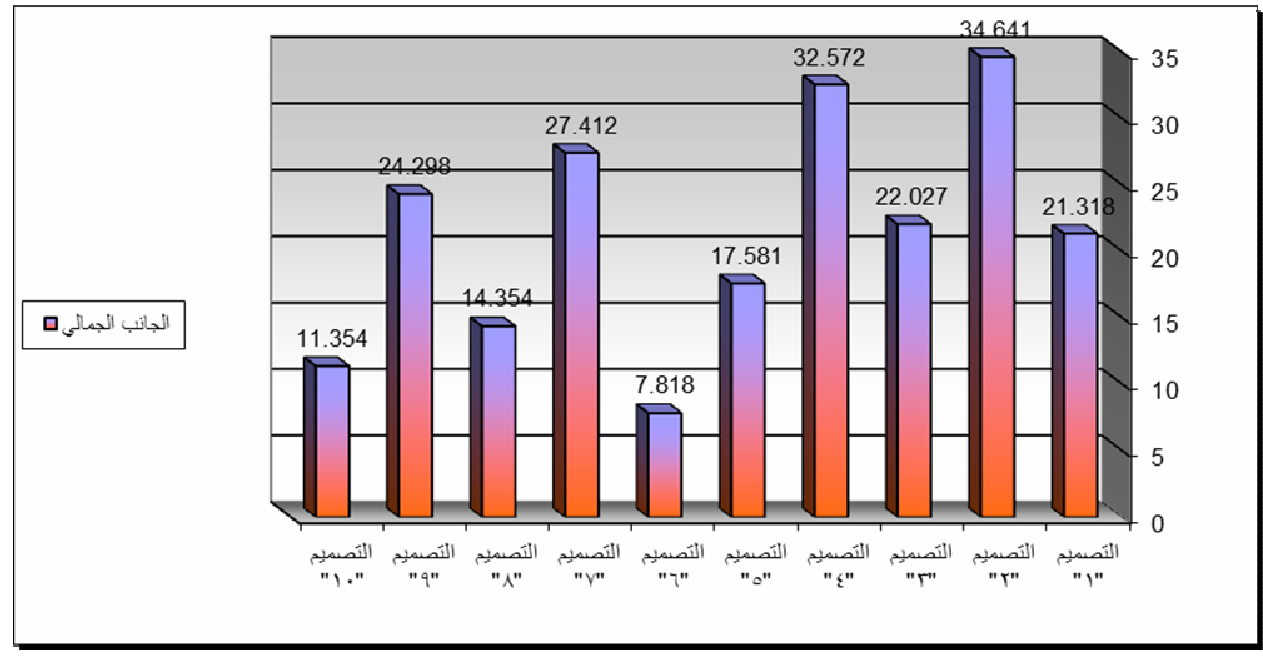

شكل ( 1 ) التصميمات العشر ِِّ المحور الجمالي وفقا لأراء المتخصصين

من الجدول والشكل السابقين يتضح أن:

ا. وجود فروق دالة إحصائيا بين التصميمات عند مستوي دلالة 0.01 ، فنجد أن التصميم "ץ"

كان أفضل التصميمات يْ تحقيق الجانب الجمالي وفقا لأراء المتخصصين ، يليه التصميه 


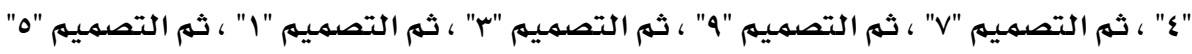

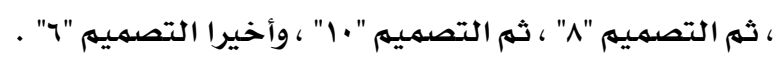

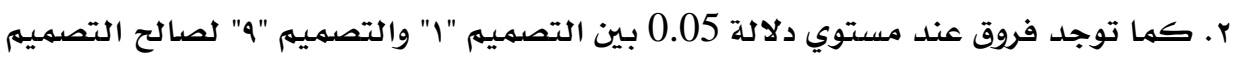

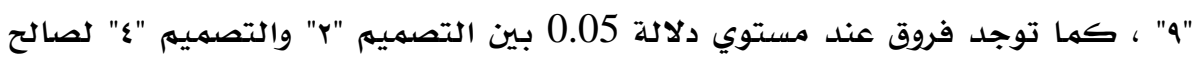

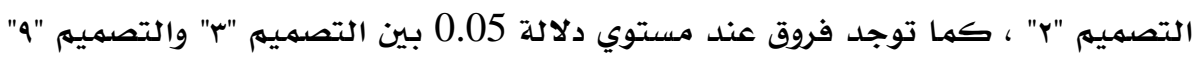

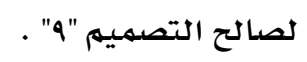

r. بينما لا توجد فروق بين التصميهم "ا" والتصميهم "r" . ل

\begin{tabular}{|c|c|c|c|c|c|c|c|c|c|c|}
\hline "التصميم "• ا" & 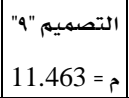 & "^ = التصميم" 29.794 & $\begin{array}{l}\text { "V" التصميم = } 7.013 \\
7\end{array}$ & م = التصميم "ז" 15.894 & التصميم "ه" & التصميه" "؟ = 17.772 & التصميم "r" & | & | التصميه" = "ا" 23.528 & التصميه \\
\hline & & & & & & & & & - & |التصميم" "ا" | \\
\hline & & & & & & & & - & $* * 7.728$ & |التصميم "ץ" || \\
\hline & & & & & & & - & $* 3.924$ & $* 3.803$ & |التصميم "r" || \\
\hline & & & & & & - & 1.951 & 1.972 & $\$ \$ 5.755$ & |التصميم "§" || \\
\hline & & & & & - & $* 9.454$ & $\star * 7.502$ & $* * 11.427$ & $* 3.699$ & |التصميم "ه" || \\
\hline & & & & - & $* * 11.332$ & 1.878 & $* * 3.830$ & 0.094 & $* * 7.633$ & |لتصميم "צ" || \\
\hline & & & - & $* 8.880$ & $* 20.213$ & $* * 10.759$ & $* 12.710$ & $* 8.786$ & $* * 16.514$ & |التصميم "V" التصيم \\
\hline & & - & $* 22.780$ & $* * 13.900$ & $* 2.567$ & $* * 12.021$ & $* * 10.070$ & $* * 13.994$ & $* * 6.266$ & |التصميم "م" || \\
\hline & - & $* 18.330$ & $\star 4.450$ & $\star 44.430$ & $* 15.763$ & $* 6.309$ & $\star \$ 8.260$ & $* 4.336$ & $* 12.064$ & |التصميم "ه" || \\
\hline- & $* * 4.078$ & $* * 14.252$ & $* 8.528$ & 0.352 & $* * 11.685$ & $* 2.230$ & $\star 4.182$ & 0.258 & $\$ 7.986$ & ||تصميم "• "1"| \\
\hline
\end{tabular}

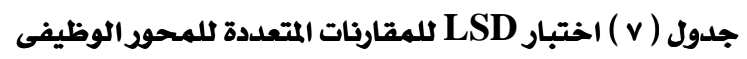

يوضح شكل الأعمدة التالى ما جاء بالجدول السابق ويؤكده. 


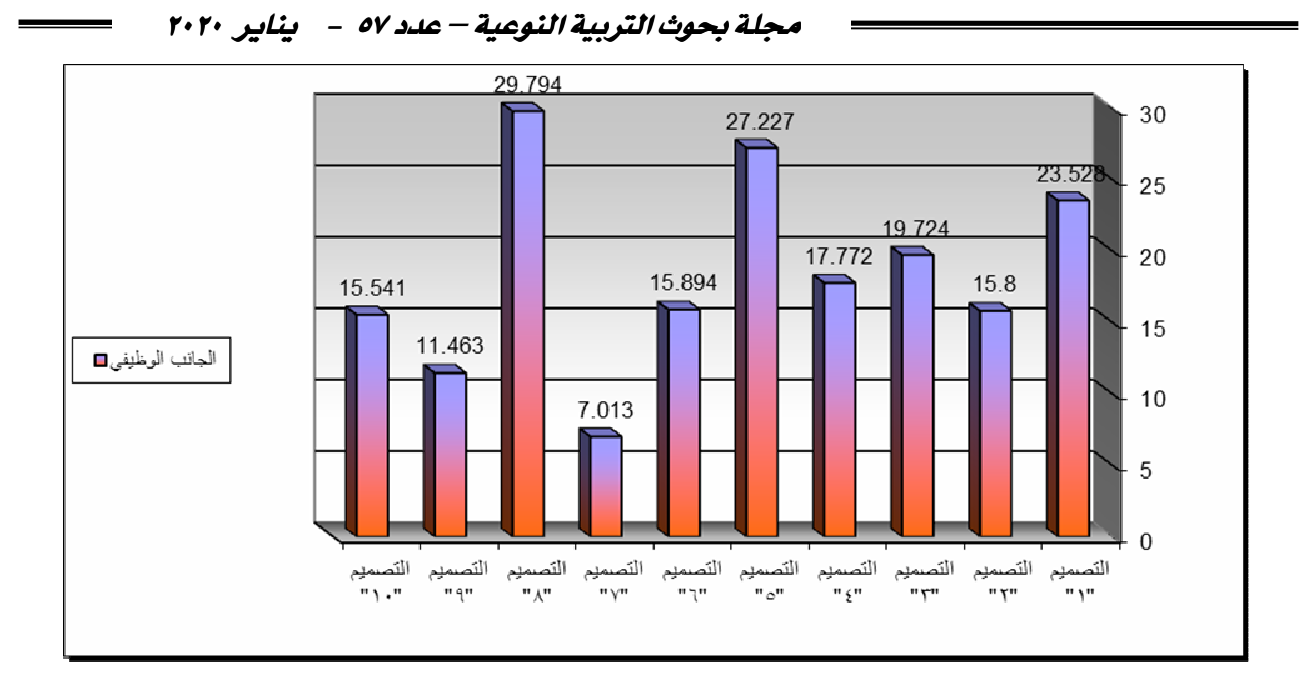

شكل ( ץ ) التصميمات العشر للمحور الوظيفي وفقا لأراء المتخصصين

من الجدول والشكل السابقين يتضح أن:

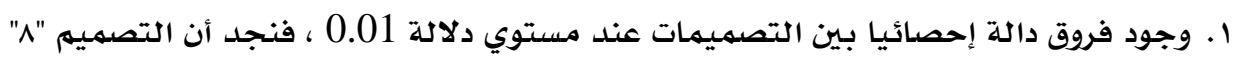

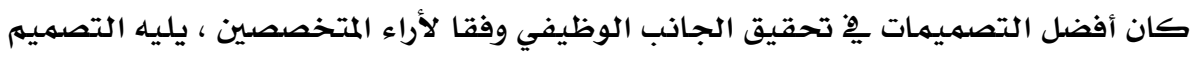

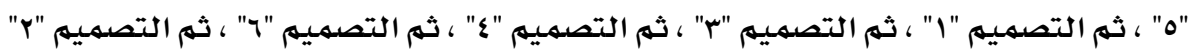

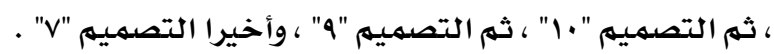

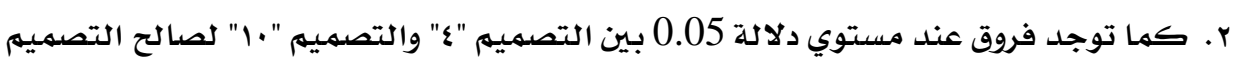

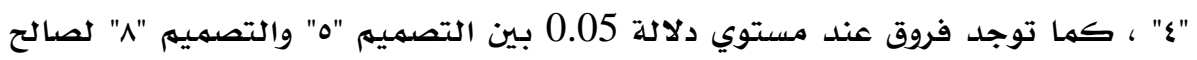

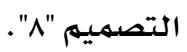

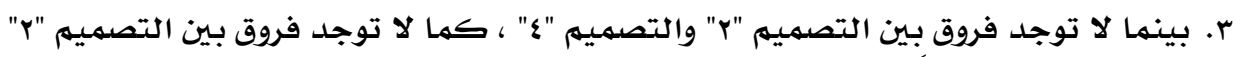

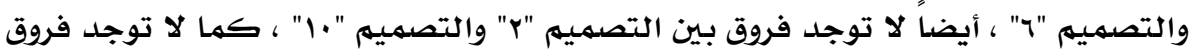

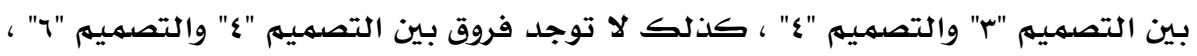

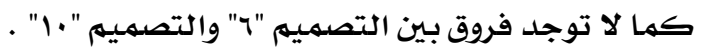


جدول ( ) اختبار LSD للمقارنات المتعددة لمجمل التصميمات

\begin{tabular}{|c|c|c|c|c|c|c|c|c|c|c|}
\hline | التصميه "• = 26.896 & 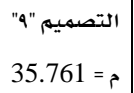 & " التصميم" = " & $\begin{array}{l}\text { "V" التصميم = } 34.426 \\
34\end{array}$ & التصميم "ף" 23.712 & التصميم "ه" & | التصميم "؟ = & التصميم "r" & | م = التصميم" "ץ" & التصميه "ا" & المجموع الكلي \\
\hline & & & & & & & & & - & التصميم "ا" \\
\hline & & & & & & & & - & $* * 5.595$ & التصميم "ץ" \\
\hline & & & & & & & - & $* * 8.690$ & $* * 3.094$ & التصميه "r" \\
\hline & & & & & & - & $* * 8.593$ & 0.096 & $* * 5.499$ & التصميه "§" \\
\hline & & & & & - & $* * 5.536$ & $* * 3.057$ & $* * 5.632$ & 0.037 & التصميم "ه" \\
\hline & & & & - & $* * 21.096$ & $* * 26.632$ & $* * 18.039$ & $* * 26.729$ & $* * 21.133$ & التصميه "צ" \\
\hline & & & - & $* * 10.713$ & $* * 10.382$ & **15.919 & $* * 7.325$ & $* * 16.015$ & $* * 10.420$ & "V" التصميم \\
\hline & & - & $* * 9.722$ & **20.436 & 0.660 & **6.196 & *2.397 & $* * 6.292$ & 0.697 & التصميم "^" \\
\hline & - & $* * 8.387$ & 1.335 & **12.049 & **9.047 & $* * 14.583$ & $* * 5.990$ & $* * 14.680$ & $* * 9.084$ & التصميه "ه" \\
\hline- & $* * 8.865$ & $* * 17.252$ & $* * 7.530$ & $* * 3.183$ & $* * 17.912$ & $* * 23.449$ & $* * 14.855$ & $* * 23.545$ & $* * 17.950$ & التصميم "• " \\
\hline
\end{tabular}

فبها يلى شكل للأعدة التى توضـح ما بالجدول السابق.

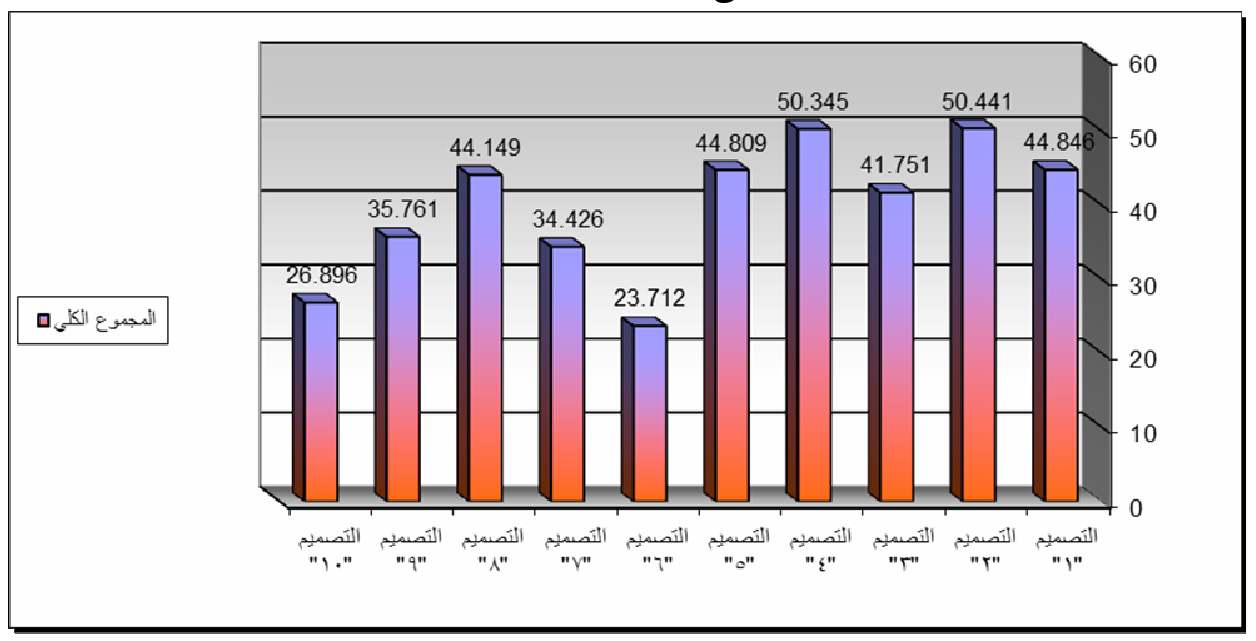

\section{شكل ( r ) مجمل التصميمات العشروفقا لأراء المتخصصين}

من الجدول والشكل السابقين يتضح أن:

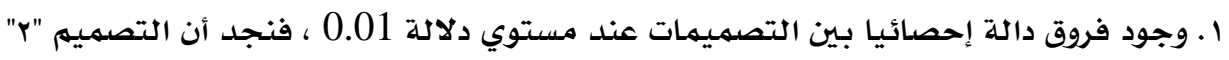

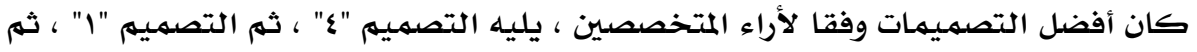

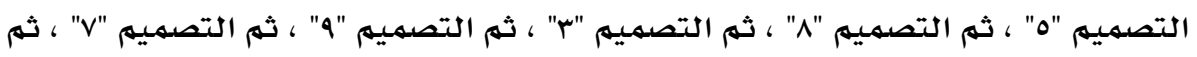

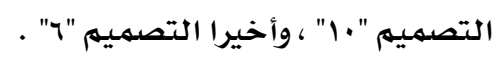




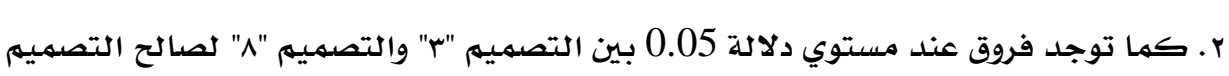
. "ᄉ"

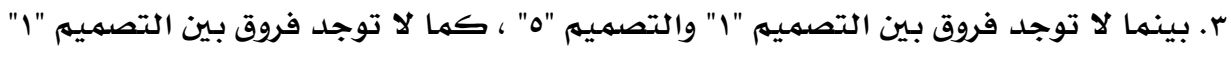

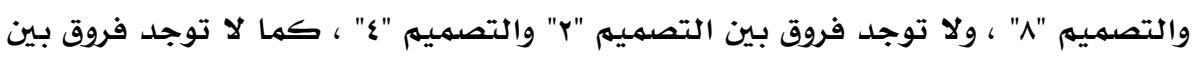

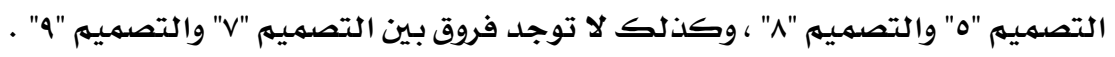

\section{تفسير ومناقشة تتائج الفرض الأول: التص

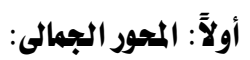

ا. يتبـين من نتائج المحور الجمالى أن أكثر تصميمـين حازا على قبول عينـة المتخصصين هما

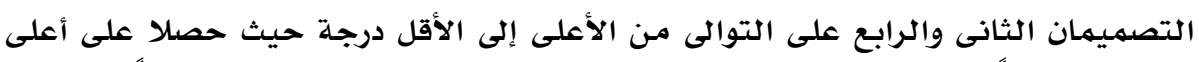

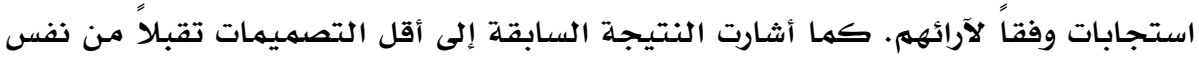
العينة هما التصميمان السادس والعاشر على الترتيب من الأقل إلى الأعلى درجية.

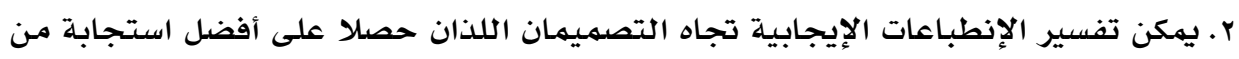

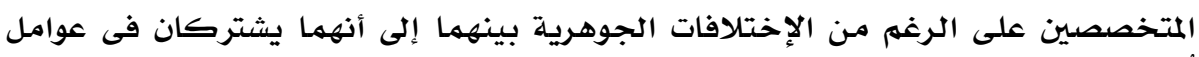

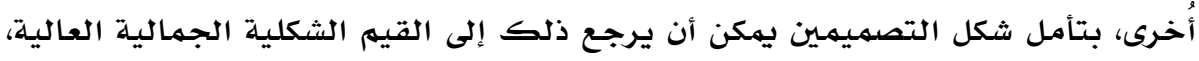

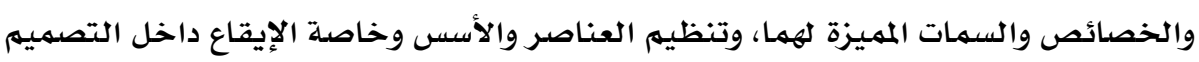

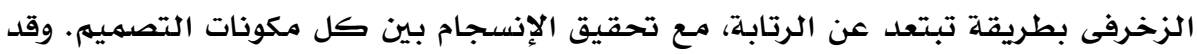

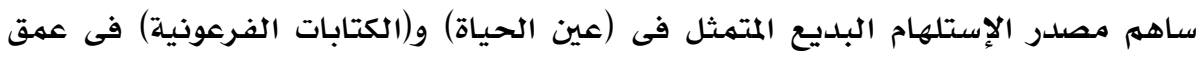

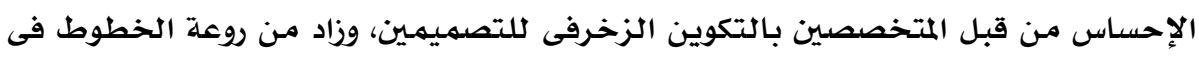

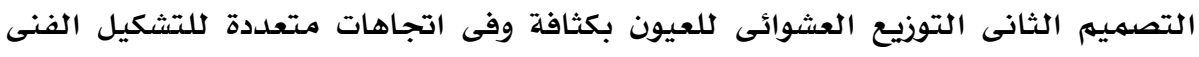

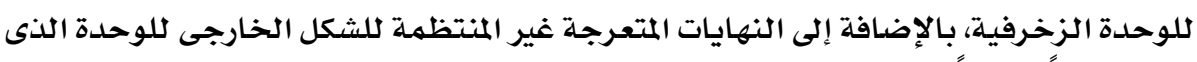

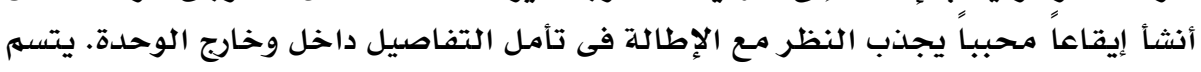

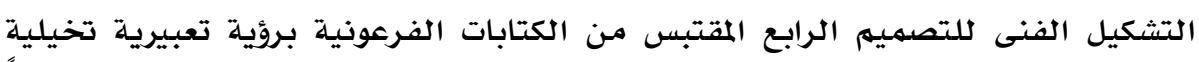

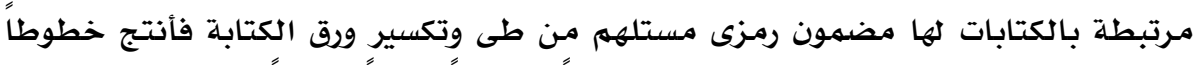

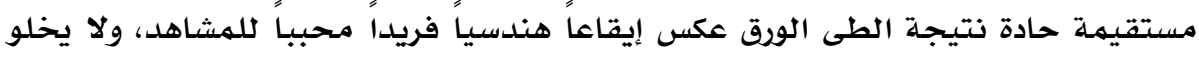

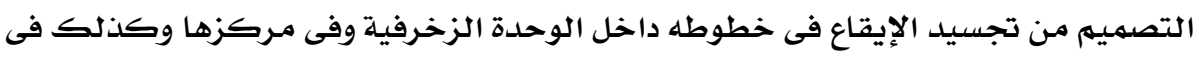

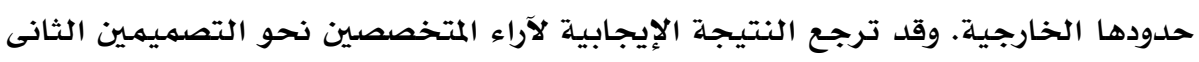

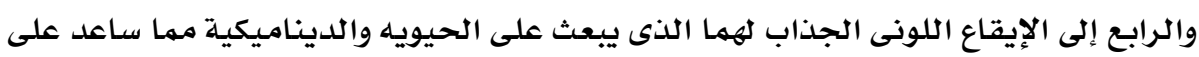

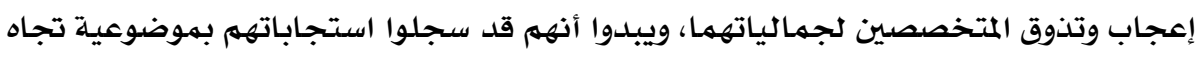

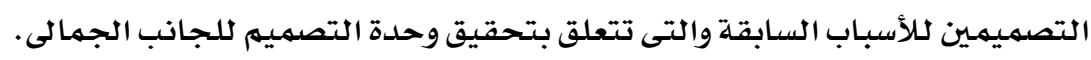

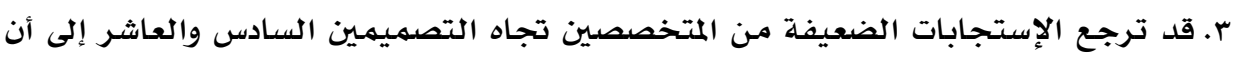

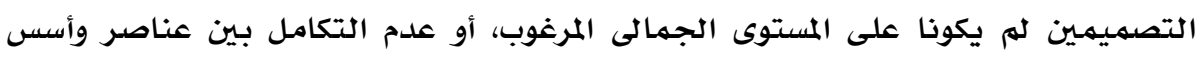

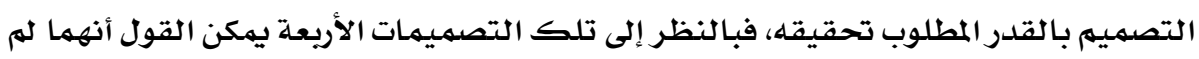




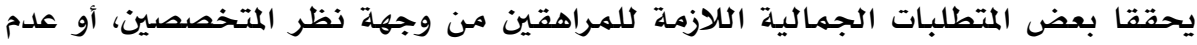

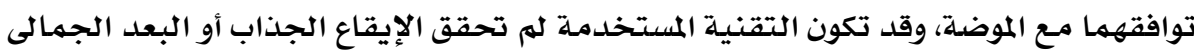
المأمول. (المال.

\section{ثانياً: المحور الوظيفى:}

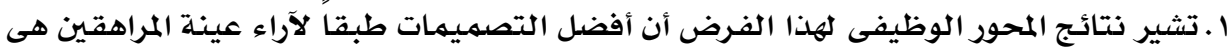

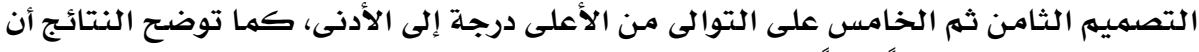

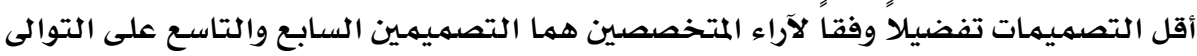

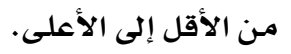

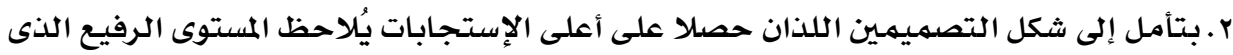

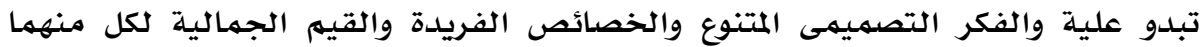

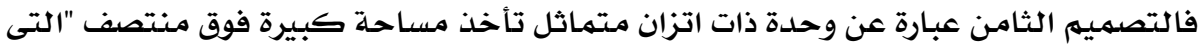

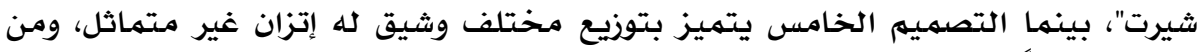

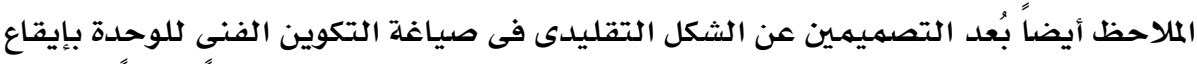

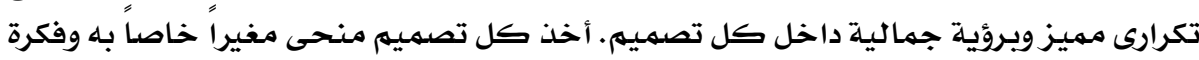

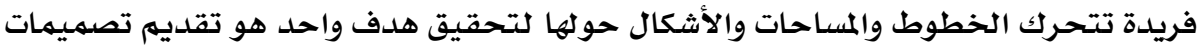

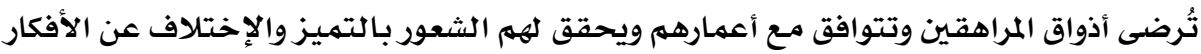

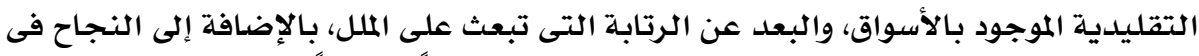

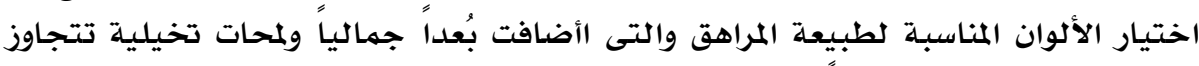

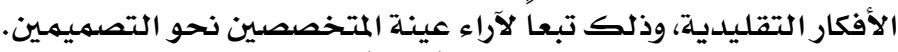

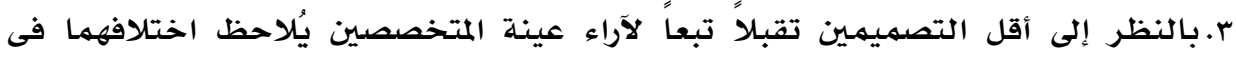

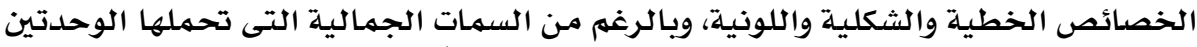

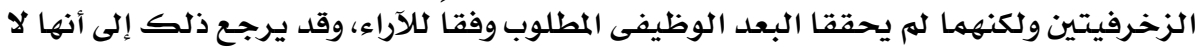

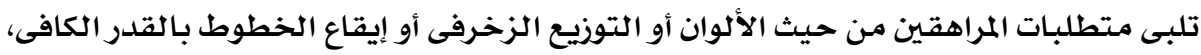

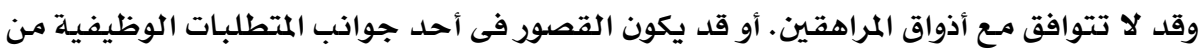

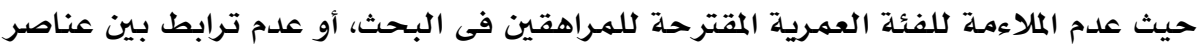
وأسس التصميهم بالقدر المناسب.

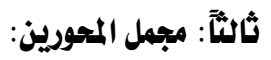

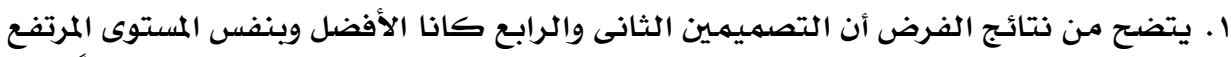

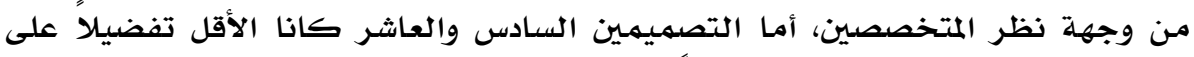

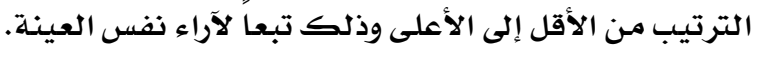

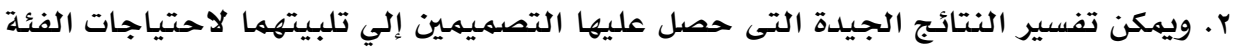

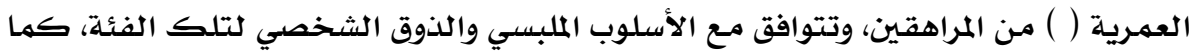

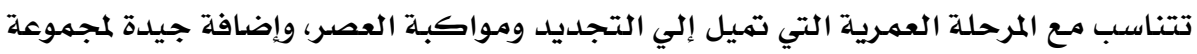




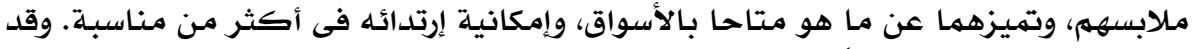

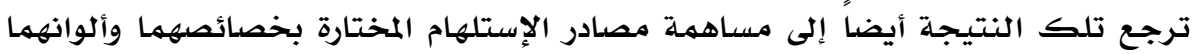

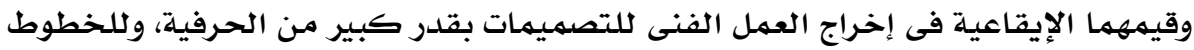

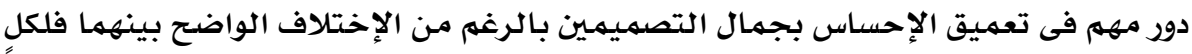

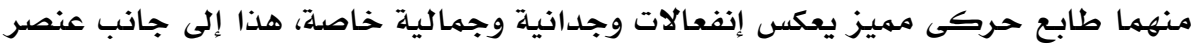

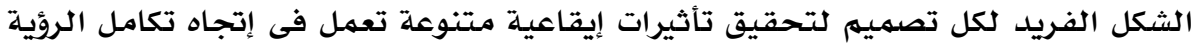

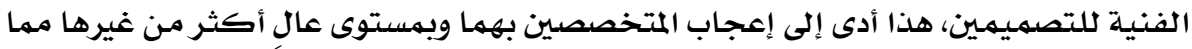

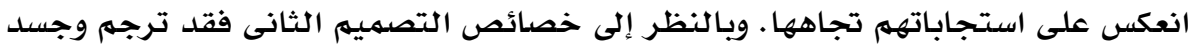

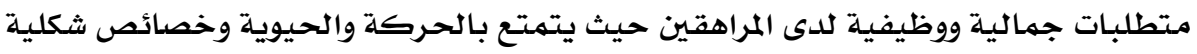

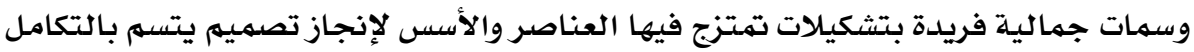

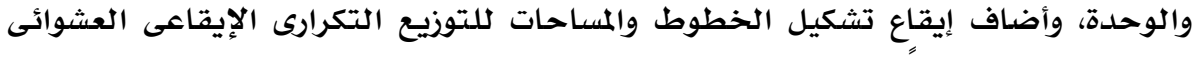

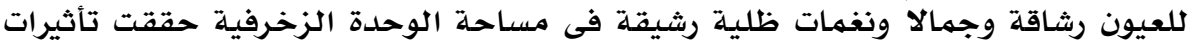

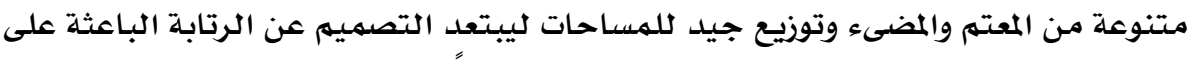

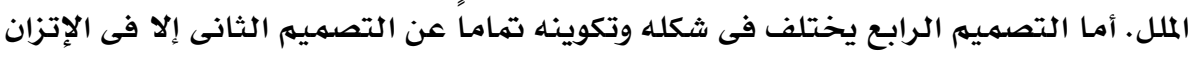

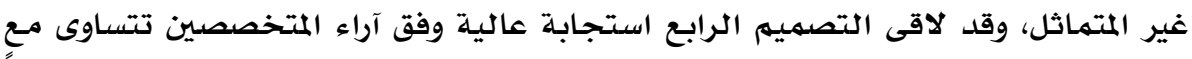

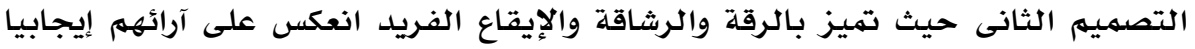

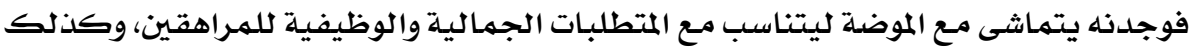

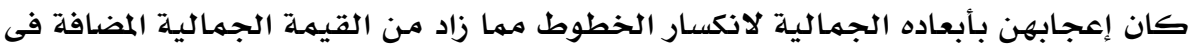

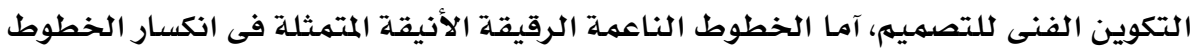

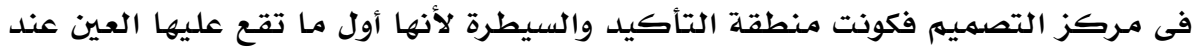

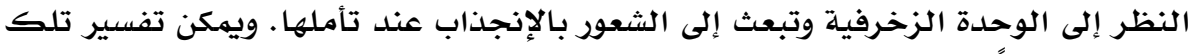

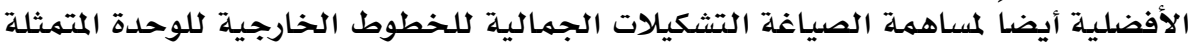

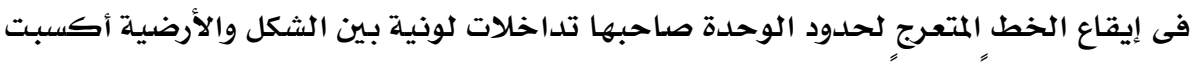

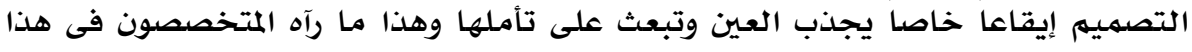

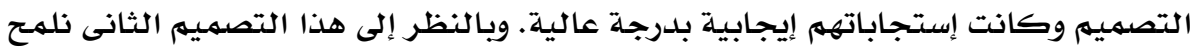

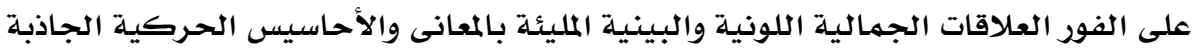

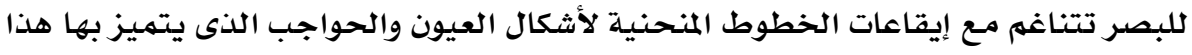

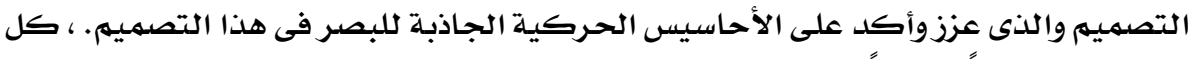

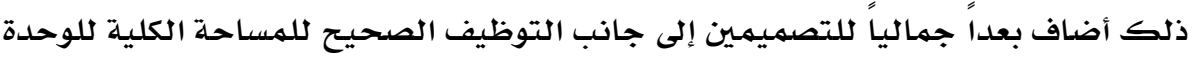

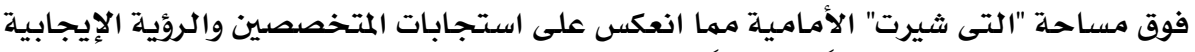
التى ظهرت فى آرئهم جمالياً ووظيفياً.

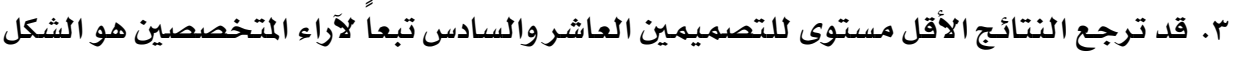

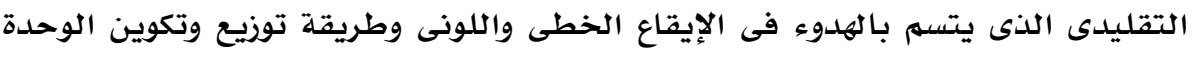


الزخرفية بطريقة رتيبة نوعاً لا تتمتع بالحركة الجريئة التى تلبى أذواق المراهقين بالقدر

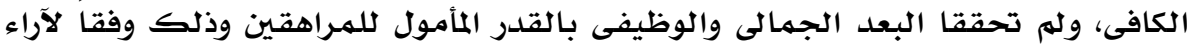

المتخصصين.

\section{ويذلك يتحقق الفرض الأول للبحث.}

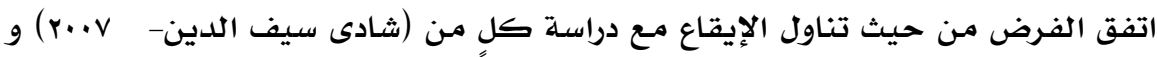

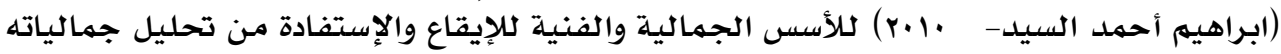

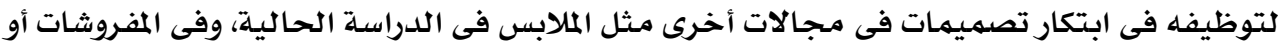

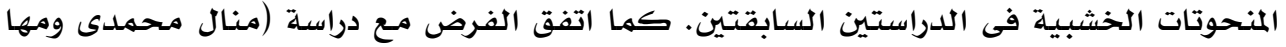

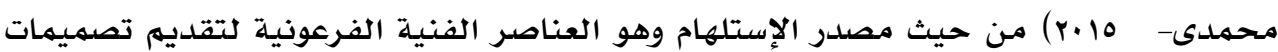

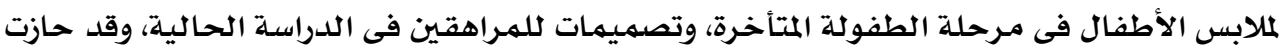

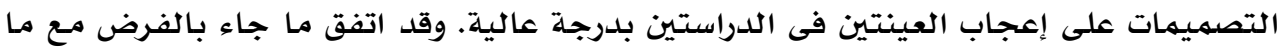

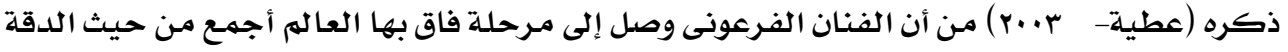

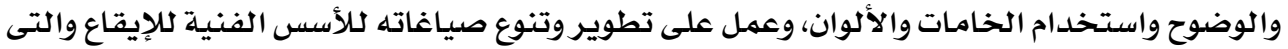

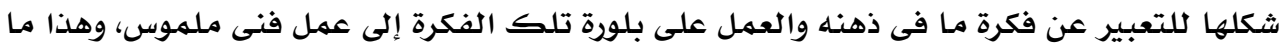

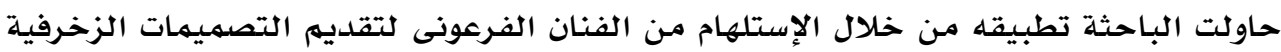

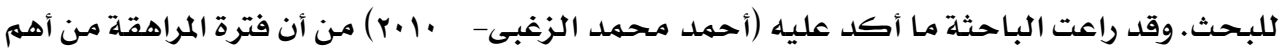

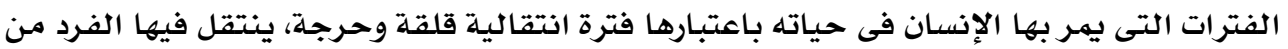

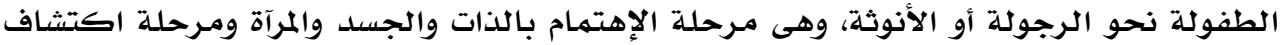

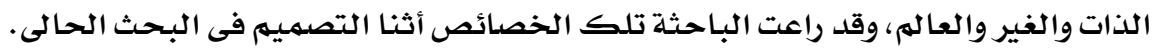

\section{الفرض الثانى:}

ينص الفرض الثانى على أنه "توجد فروق ذات دلالة إحصائية بين التصميمات العشر وفقا

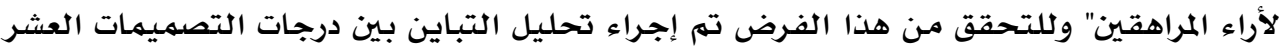

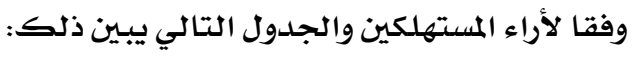

جدول ( ه) تحليل التباين لدرجات التصميمات العشروفقا لأراء المراهقين

\begin{tabular}{|c|c|c|c|c|c|}
\hline الدلالة & قيمة (ف) & درجات الحرية & متوسط المربعات & مجموع المربعات & التباين \\
\hline \multirow{3}{*}{$\begin{array}{c}0.01 \\
\text { دال }\end{array}$} & \multirow[t]{2}{*}{61.695} & 9 & 2216.686 & 19950.178 & بين المجموعات \\
\hline & & 190 & 35.930 & 6826.624 & داخل المجموعات \\
\hline & & 199 & & 26776.802 & المجموع \\
\hline
\end{tabular}

يتضح من جدول السابق إن قيمـة ( ف) كانت (61.695) وهى قيمـة دالة إحصائيا عند

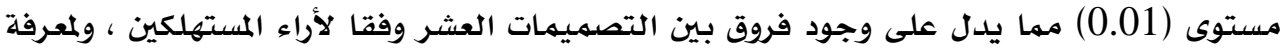

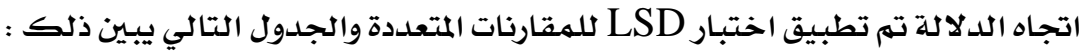


مجلة بحوث التربية النوعية - علدد - r.r. - ميناير

جدول ( • 1) اختبار LSD للمقارنات المتعددة للمراهقين

\begin{tabular}{|c|c|c|c|c|c|c|c|c|c|c|}
\hline التصميم" •"1" & التصميم "ه" 19.325 " & " التصميه = 33.350 " & " التصميه = "V" 27.361 & التصميه "ף" 12.180 " الت & التصميه "ه" 31.650 " & التصميم "؟" = 25.270 & التصميم "r" & التصميه "ץ" & التصميم" ا" 37.321 & التصميمان \\
\hline & & & & & & & & & - & التصميم"ا" \\
\hline & & & & & & & & - & $* * 7.355$ & التصميم "ץ" \\
\hline & & & & & & & - & $* * 3.776$ & $* * 3.578$ & التصميم "r" \\
\hline & & & & & & - & $* * 15.630$ & $* * 19.406$ & $* * 12.051$ & التصميم "§" \\
\hline & & & & & - & **6.380 & $* * 9.250$ & $* * 13.026$ & $* * 5.671$ & التصميم "ه" \\
\hline & & & & - & $* * 19.470$ & $* * 13.090$ & $* * 28.720$ & $* * 32.496$ & $* * 25.141$ & التصميم "ז" \\
\hline & & & - & $* * 15.181$ & $* * 4.289$ & $* 2.091$ & $* * 13.539$ & $* * 17.315$ & $* * 9.960$ & "V" التصميه \\
\hline & & - & $* * 5.989$ & $* * 21.170$ & 1.700 & $* * 8.080$ & $* * 7.550$ & $* * 11.326$ & $* * 3.971$ & التصميم "ᄉ" \\
\hline & - & $* * 14.025$ & $* * 8.036$ & $* * 7.145$ & $* * 12.325$ & $* * 5.945$ & $* * 21.575$ & $* * 25.351$ & **17.996 & التصميم "ه" \\
\hline - & *2.885 & $* * 11.140$ & $* * 5.151$ & $* * 10.030$ & $* * 9.440$ & $* * 3.060$ & $* * 18.690$ & $* * 22.466$ & $* * 15.111$ & التصميم "• "1" \\
\hline
\end{tabular}

شكل الأعمدة التالى يوضـح نتيجة الجدول السـابق

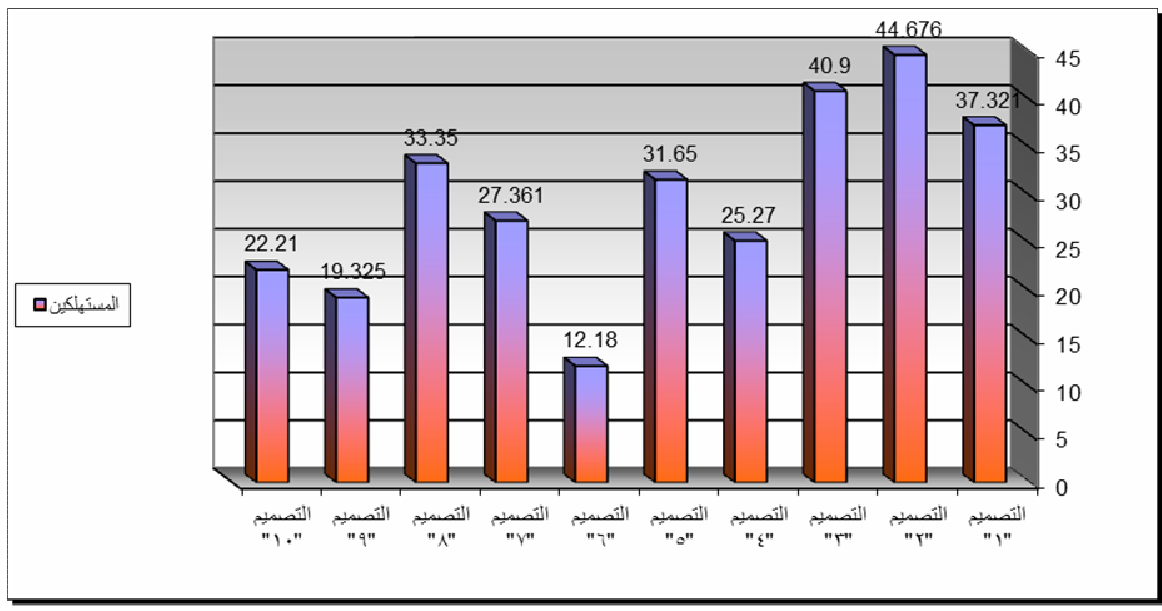

شكل ( ع) التصميمات العشروفقا لأراء المراهقين

من الجدول والشكل السابقين يتضح أن:

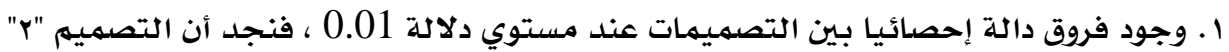

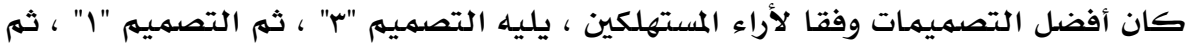

التصميم "ᄉ" ، ثم التصميم "ه" ، ثم التصميم "V" ، ثم التصميم "ع" ، ثم التصميهم ". ا" ، ثم التم

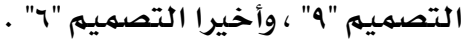


ץ. كما توجد فروق عند مستوي دلالة 0.05 بين التصميه "§" والتصميم "V" التصالح التصميم

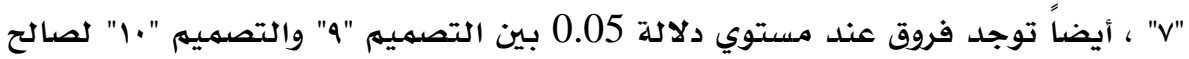

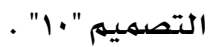

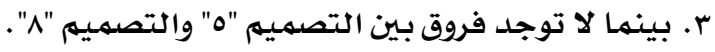

\section{تفسير ومناقشة الفرض:}

ا ـ يتضح من نتائج الفرض أن التصميمسين الثانى والثالث قد حققا أعلى تقبل من المراهقين،

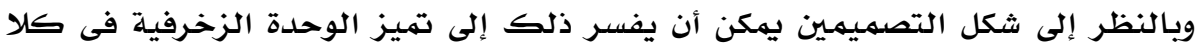

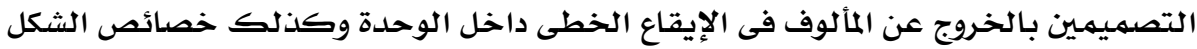

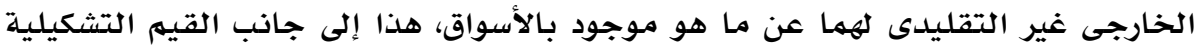

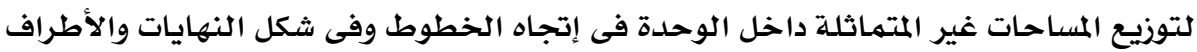

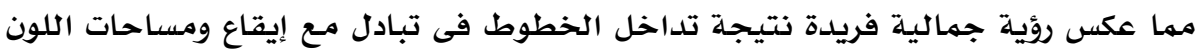

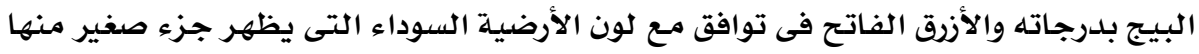

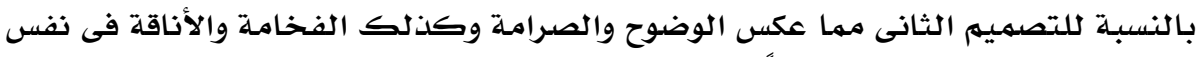

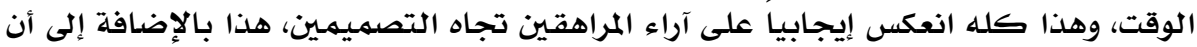

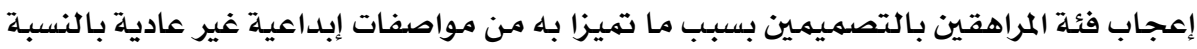

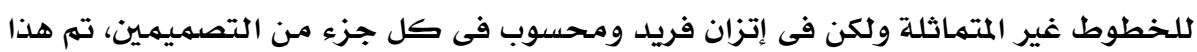

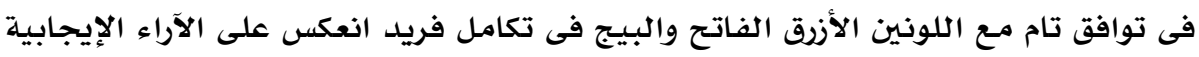

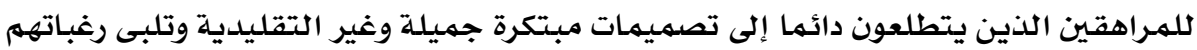
الملبسية وتتوافق مـع أذواقهم.

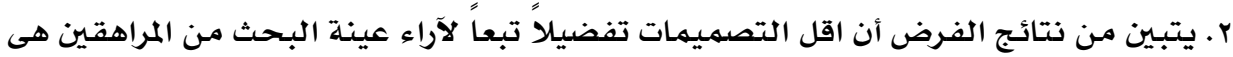

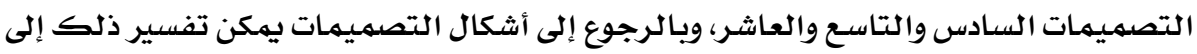

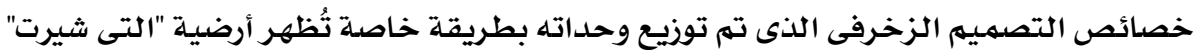

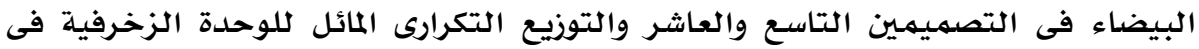

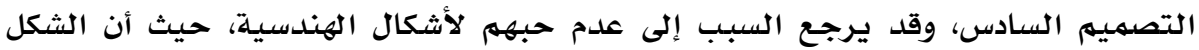

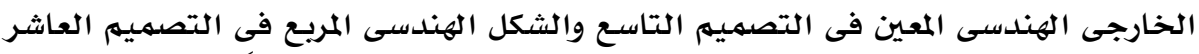

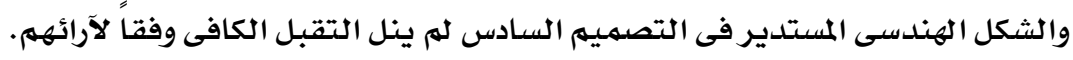

\section{ويذلك يكون الفرض الثانى للبحث قد تحقق.}

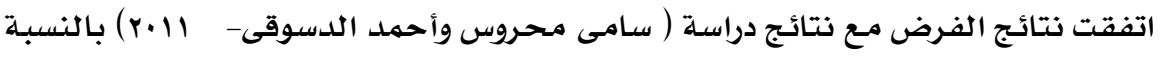

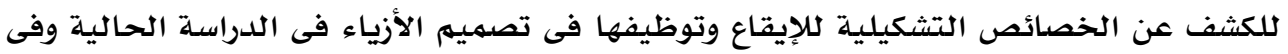

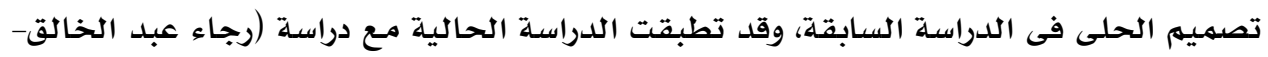

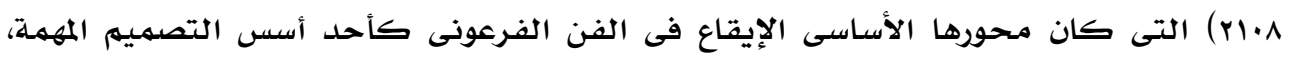

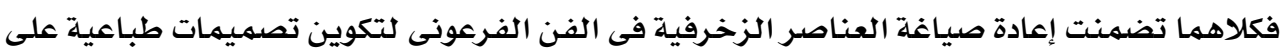




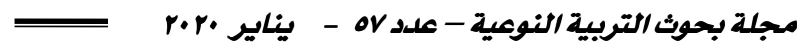

القميص الرجالى فى الدراسـة السابقة فى حين كانت الطباعة على "تى شيرت" فى الدراسـة الحالية،

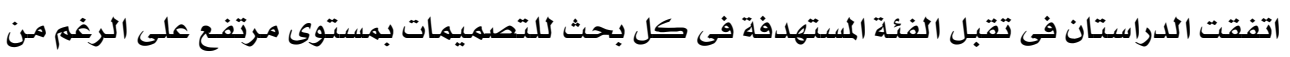

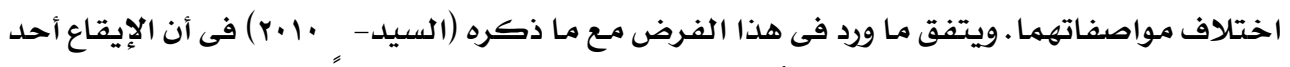

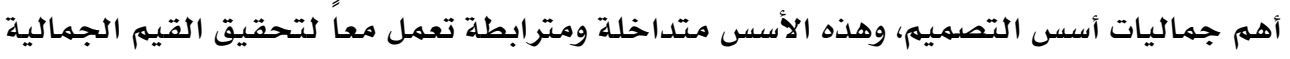

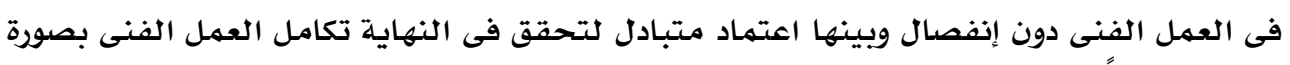

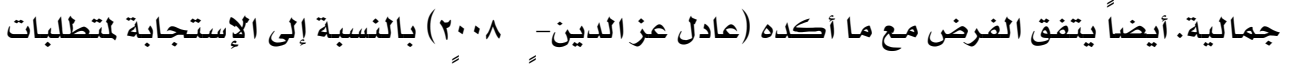

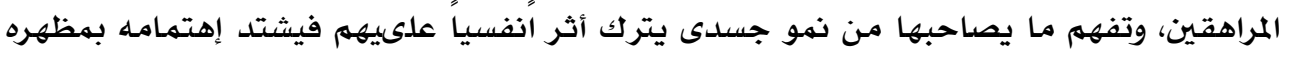

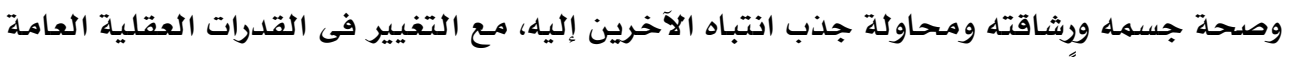

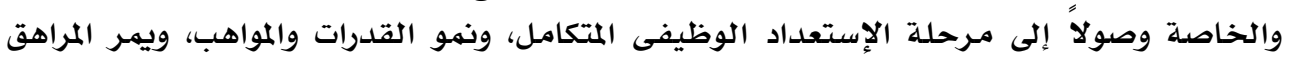

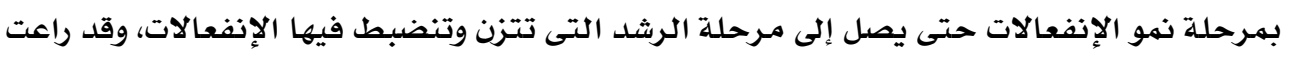

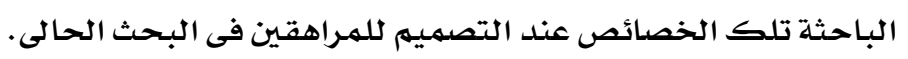

\section{الفرض الثالث :}

ينص الفرض الثالث على أنه "توجد فروق دالة إحصائياً بين متوسطى آراء الذكور والإناث

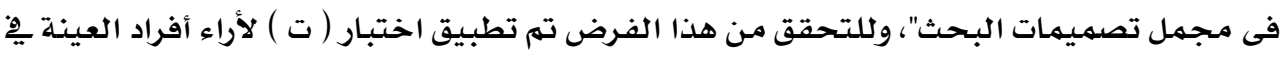
التصميمات العشر والجدول التالي يعرض البحث النتيجة:

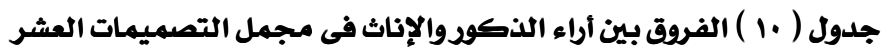

\begin{tabular}{|c|c|c|c|c|c|c|}
\hline الدلالة & قيمة (ت) & درجات الحرية & العينة & الانحراف المعياري & المتوسط الحسابي & الجنس \\
\hline \multirow{2}{*}{ لصال عند اי,. } & \multirow[t]{2}{*}{$\Lambda, r$. } & \multirow[t]{2}{*}{ in } & ir & $r, 7 r v$ & sr, 7 r & ل ذكور \\
\hline & & & $\wedge$ & $r, 91 \xi$ & ro, 01. & إناث \\
\hline
\end{tabular}

فيما يلى شكل الأعمدة الذى يبين نتيجة الدول السابق.

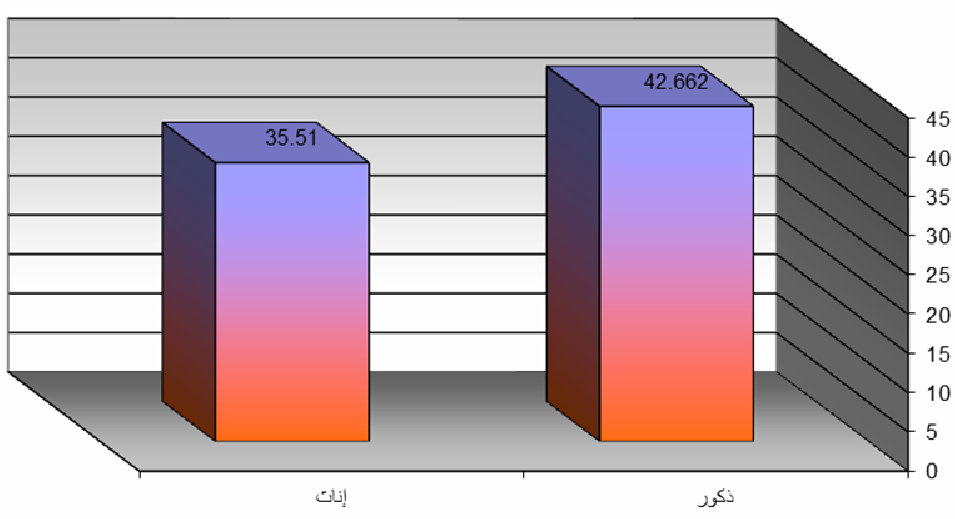

شكل ( ه ) الفروق بين آراء الذكوروالإناث ِِ2 مجمل التصميمات 


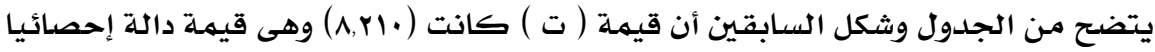

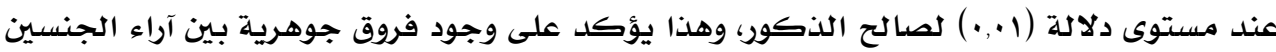
تجاه التصميمات.

\section{تفسير ومناقشة الفرض:}

يتبين من نتيجة الفرض إعجاب المراهقين الذكور بالتصميمات الزخرفية "للتى شيرتات"

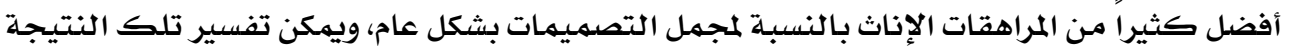

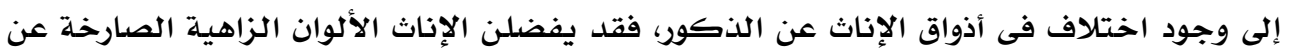

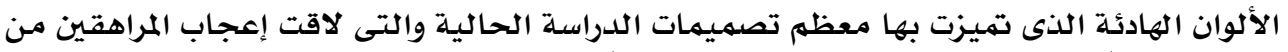

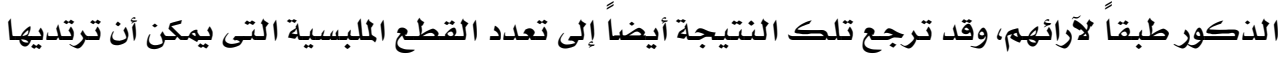

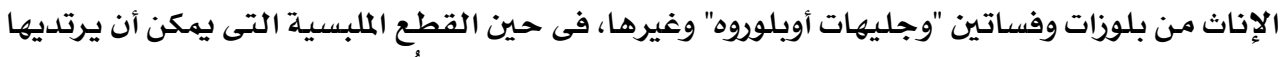

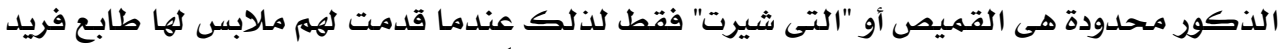

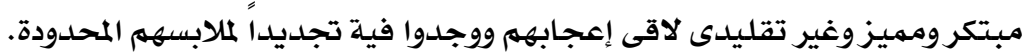
وبذلك يتحقق الفرض الثالث للبحث.

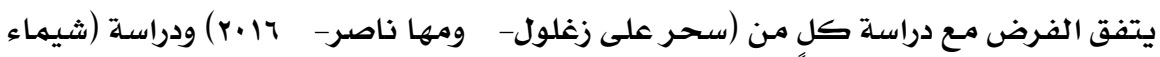

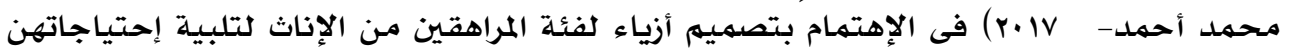

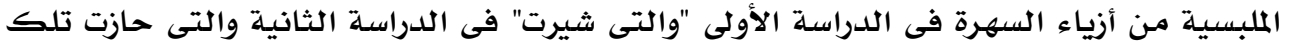

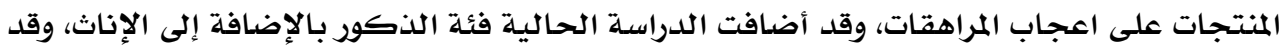

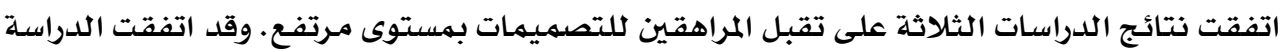

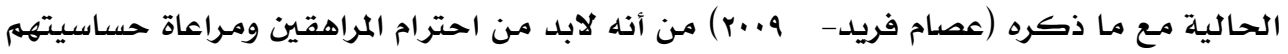

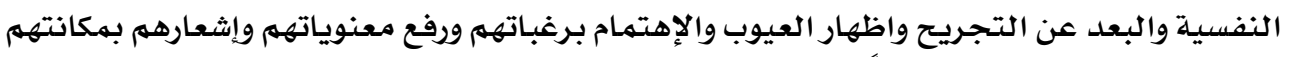

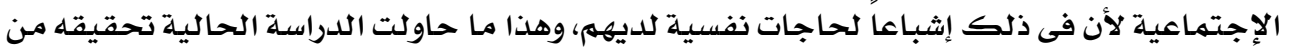
خلال الملابس.

ا. الإهتمام بتحقيق متطلبات المراهقين والإستجابة لاحتياجاتهم الملبسية من خلال ابتكار

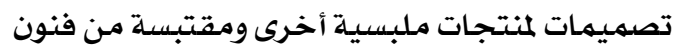

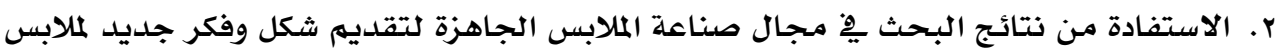
المراهقين.

r. توظيف القيم الجمالية المميزة للفن الفرعونى فى تصميم أزياء لمنتجات أخرى بصورة معاصرة.

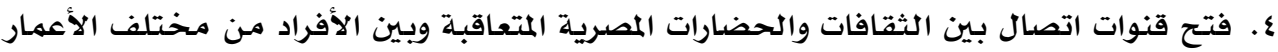

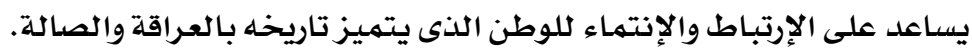

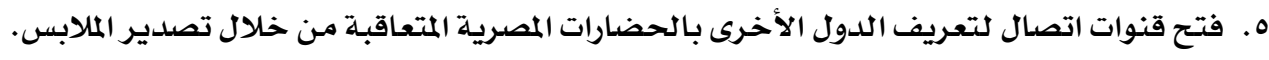




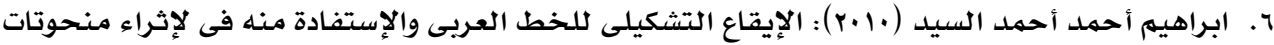

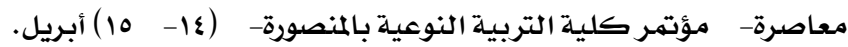

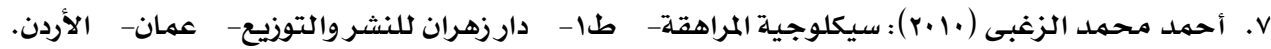
^. الدريد سيريل (·199) ) الفن المصرى القديم- ترجمة أحمد زهير- هيئة الآثار المصرية.

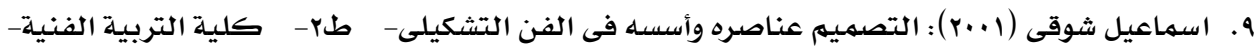
جامعة حلوان.

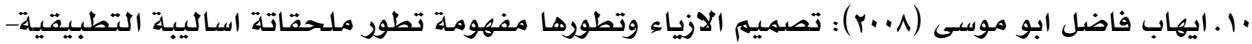

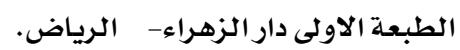

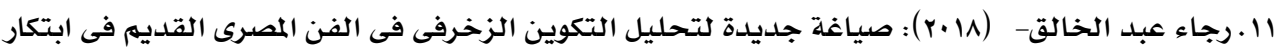

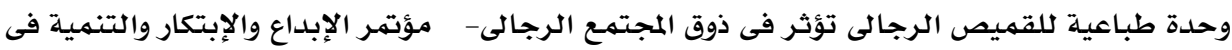

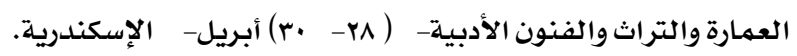

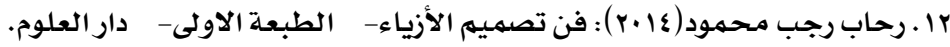
rا.ـسامى محروس وأحمد الدسوقى (11+r): القيم التشكيلية للحروف العربية كمصدر لإثراء تصميم

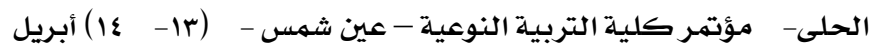

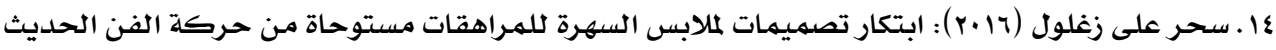

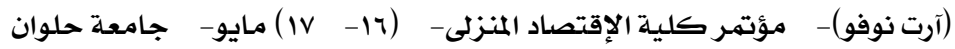
10 ـ شادى سيف الدين (Y. . . ) : القيه الجمالية للخط العربى وتطبيقاتها الوظيفية على الملابس والمفروشات

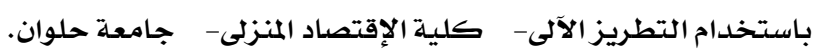
17

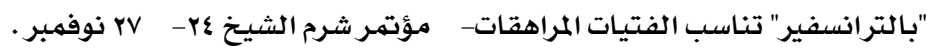

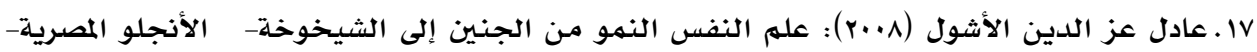
القاهرة.

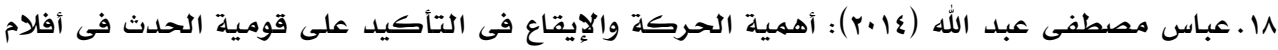
التحريك ذات الطابع العقائدى- مؤتمر كلية الفنون الجميلة- جامعة المنيا.

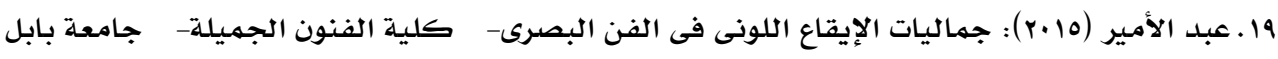

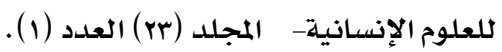

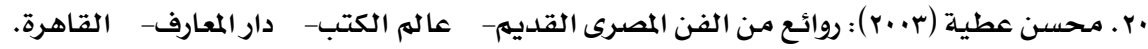

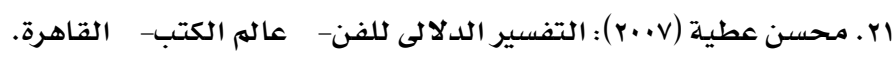

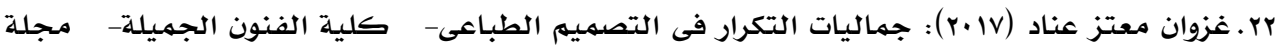

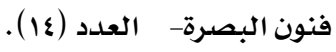

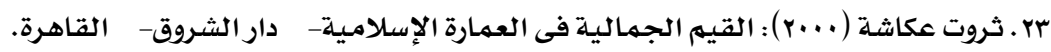

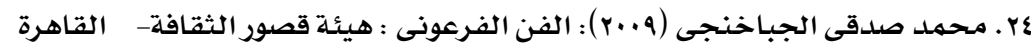




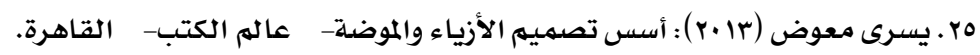

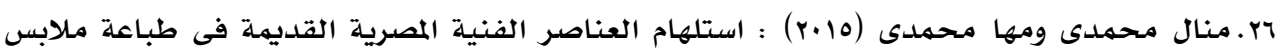

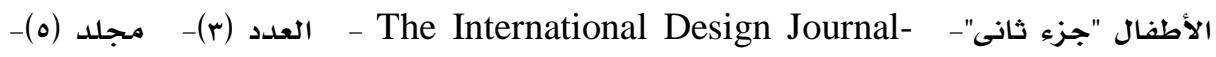
ج.P.?.

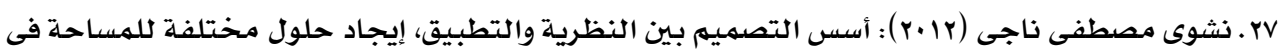

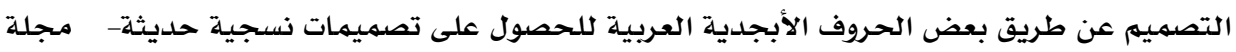

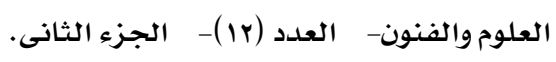

28. Ramesh Chopra (2005): Academic Dictionary of Arts shabon Book Delhi. 


\section{Aesthetics Of "Rhythm" in Pharaonic Art and It's Used in Fashion Design for Teenagers}

\section{Abstract}

Rhythm is one of the most important aesthetics of the design foundations, namely (unity - balance - proportionality - emphasis - control) and other foundations, these overlapping and interrelated working together to achieve the aesthetic values in the work of art without separation, including interdependence to achieve the integration of artistic work in aesthetic and due to the multiplicity Fine arts have varied and differed methods of treating rhythm in many works of art in various fields, and each of the arts is characterized by different rhythm sensations from the rest of the other arts, especially Paranoiac art, including a thought and a sense of rhythm, therefore, the researcher to analyze and devise the aesthetics of rhythm Paranoiac art and use it in the design of fashion for teenagers, which is a T-shirt "as a kind of fixation of Egyptian identity The researcher followed the descriptive approach with analysis and application .The researcher analyzed many of the Pharaonic sources and devised the aesthetics of the rhythm and quote a number of t-shirts and presented to both specialists and consumers to know the views. Which he formed to express an idea in his mind and work to crystallize that idea into a tangible art work that impressed adolescents 